MULTIPLE-PATHOGEN STRATEGY FOR BIOHERBICIDAL CONTROL OF SEVERAL WEEDS

By

SANKARANARAYANAIYER CHANDRAMOHAN

A DISSERTATION PRESENTED TO THE GRADUATE SCHOOL OF THE UNIVERSITY OF FLORIDA IN PARTIAL FULFILLMENT

OF THE REQUIREMENTS FOR THE DEGREE OF DOCTOR OF PHILOSOPHY

UNIVERSITY OF FLORIDA 
Copyright 1999

by

Sankaranarayanaiyer Chandramohan 
To my mom Mrs. P. Saraswathy Ammal 


\section{ACKNOWLEDGMENTS}

I express my sincere gratitude to my major advisor, Dr. Raghavan Charudattan, for his excellent guidance, encouragement, and support throughout the course of these studies and for his constructive criticisms in preparing this dissertation. I also thank the members of my supervisory committee: Dr. Megh Singh, co-chairman, Dr. Ronald M. Sonoda, Dr.

Richard D. Berger, and Dr. James F. Preston III for their guidance, suggestions, and help extended during the entire research program and in preparation of this dissertation.

I thank James T. DeValerio, Senior Biologist, for his help and friendship during the research program. I also sincerely thank the Faculty, Staff, Students, and Post-Doc members of the Plant Pathology Department. I offer my special thanks to Mr. Eldon Philman, Mr. Gene Crawford, and Mr. Lucious Mitchell for their help during the graduate program.

I want to acknowledge Professor Dr. D. Purushothaman, and Dr. Erick Vandamme for their excellent guidance and help during my graduate study at Tamilnadu Agricultural University, India (1983-1986) and at the Rijks Universiteit Ghent (RUG), Belgium (19881990), respectively.

I thank my mother, Mrs. P. Saraswathy Ammal, my brothers, Mr. S. Somasundaram, and Mr. S. Sivasankaran for shaping my career and personal life, believing in my abilities and being a source of moral support always. I deeply appreciate my family members, Mrs. Prema Somasundaram, Mrs. Lakshmi Sivasankaran, my niece Vidya, and my nephews 
Vimal, Krishna, and Sreekar for all their love and affection. I want to thank my friends and their families for their continuing friendship and support during the graduate program.

I gratefully acknowledge the financial support provided by the Florida Citrus Production Research Advisory Council, (FCPRAC) 942-33 and Florida Department of Transportation WPI-0510742, State Job No. 99700-3325-119, Contract No. B-9904. 
TABLE OF CONTENTS

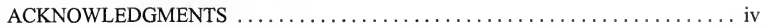

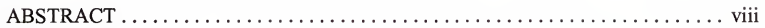

CHAPTERS

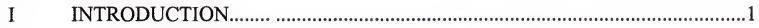

Weedy Grasses in Citrus in Florida........................................................

Chemical Control of Weedy Grasses in Citrus in Florida...........................6

Need for An Alternative Technology for Control of Grassy Weeds............7

Bioherbicidal Technology for Weed Management........................................

Enhancement of Field Efficacy of Bioherbicides.......................................12

II A MULTIPLE-PATHOGEN STRATEGY FOR BIOHERBICIDAL

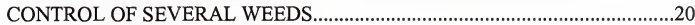

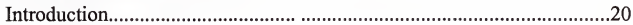

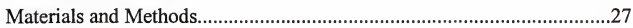

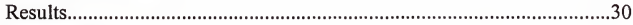

Discussion........................................................................................................

III BIOHERBICIDAL CONTROL OF WEEDY GRASSES WITH A

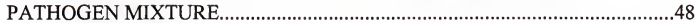

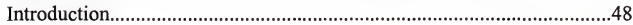

Materials and Methods............................................................................50

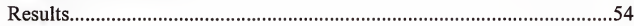

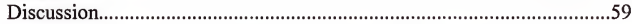

IV EVALUATION OF THE HOST-RANGES OF Drechslera gigantea, Exserohilum

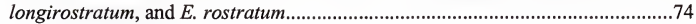

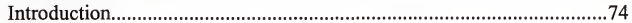

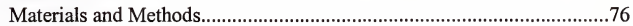

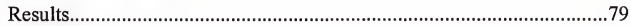

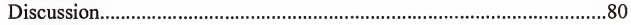


V A TECHNIQUE FOR MASS PRODUCTION AND MULTIPLE HARVESTING OF BIOHERBICIDAL FUNGI BY BIPHASIC CULTURING...........................99

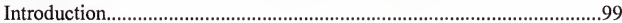

Materials and Methods............................................................................103

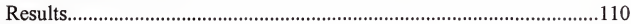

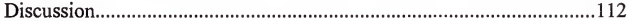

VI. FIELD EVALUATION OF A MULTIPLE-PATHOGEN STRATEGY FOR BIOHERBICIDAL CONTROL OF SEVERAL WEEDY GRASSES.................114

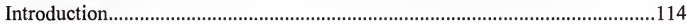

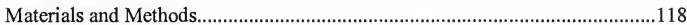

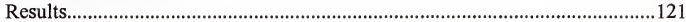

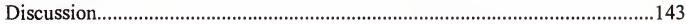

VII. FIELD EVALUATION OF A PATHOGEN MIXTURE FOR BIOHERBICIDAL CONTROL OF GUINEAGRASS...............................................................148

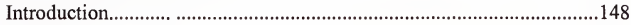

Materials and Methods.......................................................................150

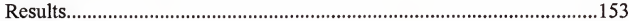

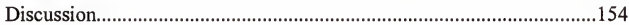

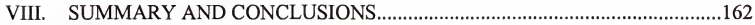

\section{APPENDICES}

A EFFECT OF LONG TERM STORAGE ON SURVIVAL OF THREE BIOHERBICIDAL FUNGI, Drechslera gigantea, Exserohilum rostraum, AND

E. longirostratum.

B EFFECT OF INOCULATION WITH Drechslera gigantea, Exserohilum longirostratum, E. rostratum, AND A MIXTURE OF ALL THREE PATHOGENS ON PANICLE NUMBER AT 14 WEEKS AFTER INOCULATION.

C WEATHER DATA

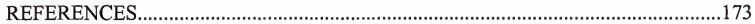

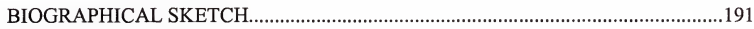




\begin{abstract}
Dissertation Presented to the Graduate School of the University of Florida in Partial Fulfillment of the Requirements for the Degree of Doctor of Philosophy
\end{abstract}

\title{
MULTIPLE-PATHOGEN STRATEGY FOR BIOHERBICIDAL CONTROL OF SEVERAL WEEDS
}

\author{
By \\ Sankaranarayanaiyer Chandramohan
}

August 1999

Chairperson: Raghavan Charudattan

Major Department: Plant Pathology

A novel approach, termed the "multiple-pathogen strategy", in which three or more host-specific fungal plant pathogens are combined and applied inundatively for the control of several weeds was evaluated. In a model system, the following weed species were tested: pigweed (Amaranthus hybridus), sicklepod (Senna obtusifolia), and showy crotalaria (Crotalaria spectabilis). The pathogens tested were Phomopsis amaranthicola (pigweed pathogen), Alternaria cassiae (major host, sicklepod; alternative host, showy crotalaria), Colletotrichum dematium f. sp. crotalariae and Fusarium udum f. sp. crotalariae (showy crotalaria pathogens). Spore suspensions of each pathogen $\left(10^{6}\right.$ spores per $\left.\mathrm{ml}\right)$ and a mixture of the four pathogens $\left(1: 1: 1: 1 \mathrm{v} / \mathrm{v}\right.$; total $10^{6}$ spores per $\left.\mathrm{ml}\right)$ were tested on the weed seedlings grown together in pots. The pathogens completely killed their respective weed hosts, when 
used alone or as a mixture. The growth pattern of each pathogen was conditioned by specific interactions with the leaf surfaces of the different hosts, whether the pathogen was applied alone or in a mixture. The pathogens did not lose their efficacy and host-specificity when used as a mixture, and therefore, the pathogen mixture could be used to control several weeds simultaneously.

Similarly, the bioherbicidal control of several weedy grasses with a pathogen mixture was evaluated using three fungi indigenous to Florida: Drechslera gigantea, Exserohilum longirostratum, and Exserohilum rostratum isolated from large crabgrass (Digitaria sanguinalis), crowfootgrass (Dactyloctenium aegyptium), and johnsongrass (Sorghum halepense), respectively. In trials conducted in a greenhouse, each pathogen $\left(2 \times 10^{5}\right.$ spores $/ \mathrm{ml})$ as well as a mixture of the pathogens $\left(1: 1: 1 \mathrm{v} / \mathrm{v}\right.$; total $2 \times 10^{5}$ spores $\left./ \mathrm{ml}\right)$ caused $82.5-100 \%$ disease severity on large crabgrass, crowfootgrass, johnsongrass, southern sandbur (Cenchrus echinatus), guineagrass (Panicum maximum), Texas panicum (Panicum texanum), and yellow foxtail (Setaria glauca). In a host-range trial, crop plants tested were either immune or resistant to each pathogen and the pathogen mixture.

In separate field trials conducted in Florida, an emulsion-based inoculum of $D$. gigantea, E. longirostratum, and E. rostratum $\left(5 \times 10^{5}\right.$ spores $\left./ \mathrm{ml}\right)$ and a mixture of these pathogens $\left(1: 1: 1 \mathrm{v} / \mathrm{v}\right.$; total $5 \times 10^{5}$ spores $\left./ \mathrm{ml}\right)$ almost completely killed the seven weedy grasses mentioned above, and also, a natural population of guineagrass, a major weed in citrus in Florida. The weed control lasted for more than 10 weeks. Thus, D. gigantea, E. longirostratum, and E. rostratum have potential to be developed as bioherbicides for the management of weedy grasses. The multiple-pathogen strategy is a novel and effective means of weed control. 


\section{CHAPTER I \\ INTRODUCTION}

Weeds are managed in crops mainly by using cultural, mechanical, and chemical methods (Dao, 1987; Standifer et al., 1984; Teasdale et al., 1991). Chemical herbicides have usually provided excellent weed control in intensively managed crop-production systems, but increased costs of herbicides and application have reduced net profits (Lybecker et al., 1984; Nastasi et al., 1986). Increasingly, excessive use of agrochemicals in weed control has led to many environmental problems such as phytotoxicity to crops, persistence in soil, contamination of surface water and eventually groundwater, and development of resistance to herbicides in weeds (Lo et al., 1984; Schroeder \& Banks, 1986; Murphy et al., 1986). Due to the increasing cost of chemical herbicides and other environmental concerns, an environmentally friendly alternative to chemical control of weeds is desirable. This provides an opportunity to develop a biological control strategy for weeds, such as the use of plant pathogens as bioherbicides.

\section{Weedy Grasses in Citrus in Florida}

Weeds compete with citrus plants for moisture, nutrients, and light and can inhibit the growth of young trees and delay fruit production. Among the most problematic weeds are some annual and perennial weedy grasses that also are among the world's worst weeds in many crops in several countries (Holm et al., 1977). These are: bahiagrass, Paspalum 
notatum Fluegge; bermudagrass, Cynodon dactylon (L.) Pers.; large crabgrass, Digitaria sanguinalis (L.) Scop.; crowfootgrass, Dactyloctenium aegyptium (L.) Willd.; goosegrass, Eleusine indica (L.) Gaertn.; guineagrass, Panicum maximum Jacq.; johnsongrass, Sorghum halepense (L.) Pers.; napiergrass, Pennisetum purpureum Schumach.; natalgrass, Rhynchelytrum repens (Willd.) C.E.Hubb.; southern sandbur, Cenchrus echinatus L.; Texas panicum, Panicum texanum L.; torpedograss, Panicum repens L.; vaseygrass, Paspalum urvillei Steud.; and yellow foxtail, Setaria glauca (L.) Beauv. These weedy grasses cause yield losses in many crops (Weller et al., 1985; Bridges \& Chandler, 1987; Murphy et al., 1986). These weeds are difficult to control, either because of their tolerance to available chemical herbicides or due to their growth habits that enable them to escape other control practices. The following is a brief description of the major weedy grasses in Florida.

Bahiagrass is a perennial native to Central and South America from Mexico to Argentina. It has been introduced into the United States in Florida and along the Gulf Coast. It is a tufted and spreading herb with a terminal pair of racemes, a thick scaly rhizome, and a seedhead that has $2-3$ branches. Its deep rooting habit helps it to withstand considerable drought. It is widely distributed throughout the southeastern United States.

Bermudagrass is a warm-season perennial native to tropical and warm, temperate regions throughout the world. It was introduced from Africa, and is an important pasture grass in southern United States. It forms rhizomes and stolons and a turf of fine leaves and 3-9 finger-like spikelets. It occurs in open places, pastures, and most cultivated areas. It becomes a serious weed when established. It is a troublesome weed of cultivated land and is most difficult to eradicate. 
Southern sandbur is an annual and a native of tropical America and West Africa. It has a distinctive spiny "bur" on seeds. It is a common weed in tropical areas, and it occurs in West Indies, Mexico, Uruguay, India, and Africa. In the United States, it occurs along the South Atlantic coast and the southern border area of the United States. It is a major weed of many cultivated crops including citrus.

Goosegrass is a warm-season annual native to the Old World. It is tufted with branched stems. The stems are flattened and almost parallel to the ground on young plants. The seedhead has 1-13 finger-like spikelets, one of them frequently below terminal clusters. It occurs throughout all the United States, and is a common weed in the warmer regions.

Guineagrass is a perennial (in mild climates) and is a native of Africa. It is rhizomatous and a copious seed producer. It has two biotypes: narrowleaf and broadleaf types. It grows erect and tall up to $4-5 \mathrm{~m}$. Narrow-leaf guineagrass poses a major weed problem in citrus in Florida (Akins, 1994). It has been spreading throughout the citrus growing regions in Florida, and this weed adds significantly to the cost of weed management programs (Hall et al., 1998). It was first discovered on the east coast of Florida in the Indian River/Fort Pierce area in 1984. Since then, it has spread to the central and southern parts of the state because of its abundant seed production. The prolific spreading of the weed and its tolerance to chemical control has warranted immediate alternative control measures (Akins, 1994). The weed thrives in soils with high nutrient levels and is highly competitive with other plants and weeds. It successfully displaces weeds like torpedograss and bermudagrass. Narrow-leaf guineagrass is believed to have developed through long-term use of certain herbicides and cultural practices in Florida. It is easily spread by mowing and other mechanical operations within citrus groves. It grows into clumps that can vine into trees, 
thus making spray operations difficult.

Johnsongrass is a perennial and is native of southern Eurasia east to India. It is coarse and forms distinctive thick scaly rhizomes, and grows $3-5 \mathrm{~m}$ tall. Johnsongrass is a perennial that is capable of reproducing by seeds or rhizomes. It is one of the most troublesome weeds in the southern United States (McWhorter, 1971). It is cultivated for forage, but becomes a troublesome weed. It is a native of the Mediterranean region. It occurs throughout approximately the southern half of the United States.

Large crabgrass is a summer annual and is a native of Europe. It occurs throughout all the United States. It is tufted, prostrate to spreading, with branched stems that root at the nodes. The seedhead has $4-6$ branches, and second glume is $1 / 2$ the length of the spikelet. It is a major weed in lawns and cultivated ground.

Crowfootgrass is a summer annual. It is commonly found in the United States, West Indies, Central and South America, Australia, Europe, and Asia. The spikelets are arranged on 2 to 5 "fingers" at the tip of the stem giving the seedhead a "crowfoot" appearance. It reproduces by seed.

Texas panicum is a summer annual native to the eastern USA and West Indies. It is coarse, tufted, creeping, or decumbent. It has soft, velvet-like pubescent leaves. Texas panicum is a major grass weed in peanuts in Alabama, Georgia, Florida, and in some areas of Oklahoma and Texas. It competes with peanut and reduces yields. It also interferes with peanut harvest due to its extensive root system (Wilcut et al., 1987).

Torpedograss is a perennial with robust, creeping, sharply pointed rhizomes. Stems are stiff and erect. Leaves are folded or flat and sparsely hairy on the upper surface. Seedheads have stiff ascending branches. It reproduces primarily by rhizomes. It is found 
in the Gulf Coast region to the southwestern United States, from Florida to Texas. It also occurs in Europe, Hawaii, and tropical regions of Asia and Africa. It has become a troublesome weed and a significant competitor in young citrus groves in Florida. It spreads mainly vegetatively by rhizomes in the United States (Baird et al., 1983; Hall et al., 1998). Vaseygrass is a perennial, and got introduced into Florida from South America. It is coarse, tufted, erect, and grows up to 2-m tall. The spikelets are hairy and roots are fibrous with very short rhizomes. The seed-heads have 4 to 30 spreading branches. This grass reproduces by seed, and occurs in ditches, fields, pastures, disturbed areas, and pinelands, usually where the soil is moist. It occurs throughout the southeastern United States.

Yellow foxtail is a summer annual and is a native of tropical and warm regions of the Old World. It was introduced from Europe, and occurs as a weed of cultivated fields throughout all the United States. It is tufted, erect, and grows up to $1.3 \mathrm{~m}$ tall. It has hairy leaf sheath margins with fringed membranous ligule, and the roots are fibrous. The seedhead is yellowish with five or more bristles per spikelet.

Napiergrass is a tall, robust, densely tufted, perennial grass. It is a native of tropical Africa, and it has become widespread throughout the tropics and subtropics. It usually encroaches into fields from ditch banks. It spreads by short creeping rhizomes $15-$ to $25-\mathrm{cm}$ in length. The inflorescence is a compact, erect, bristly, and cylindrical spike ( 8 - to $30-\mathrm{cm}$ long and 1.5 - to $3.0-\mathrm{cm}$ wide), and is usually yellowish or tinged with brown or purple color. The spikelets are arranged around a hairy axis, and they fall from the axis at maturity. Each spikelet or a group of spikelets is surrounded by numerous, rough, dark yellow, brownish or purplish bristles (5- to 14- mm long). It is a principal weed of citrus in Florida, USA. 
Natalgrass is an erect-growing annual with herbaceous stem and leaves. It reproduces by seeds and stolons. The panicle is red to pink in color with silky hairs. It is a native of Africa. It is occasionally cultivated as an ornamental in Southwest United States, and is also commonly found within citrus groves of Florida, USA.

\section{Chemical Control of Weedy Grasses in Citrus in Florida}

Weedy grasses in citrus in Florida are managed by using a combination of chemical and mechanical control methods. Both preemergence and postemergence chemical herbicides are being used to control weedy grasses (Futch, 1997; Futch et al., 1999). The preemergence herbicides are as follows: bromacil (5-bromo-6-methyl-3-(1-methylpropyl)2,4(1H,3H) pyrimidinedione), diuron ((( $\mathrm{N}^{\prime}-(3,4$-dichlorophenyl)- $\mathrm{N}, \mathrm{N}$-dimethylurea)), norflurazon (4-chloro-5-(methylamino)-2-(3-(trifluoromethyl)phenyl)-3(2H)-pyridazinone), oryzalin (4-(dipropylamino)-3,5-dinitrobenzenesulfonamide), oxyfluorfen (((2-chloro-1-(3ethoxy-4-nitrophenoxy)-4-(trifluoromethyl)) benzene), simazine (6-chloro-N,N'-diethyl1,3,5-triazine-2,4-diamine), and thiazopyr (methyl 2-(difluoromethyl)-5-(4,5-dihydro-2thiazolyl)-4-(2-methylpropyl)-6-(trifluoromethyl)-3-pyridinecarboxylate). The postemergence herbicides are as follows: sethoxydim (\{2-[1-(ethoxyimino) butyl]-5- [2(ethylthio)propyl]-3- hydroxy -2- cyclohexen-1-one $\})$, fluazifop-butyl (\{(R)-2-[4-[[5(trifluoromethyl)-2-pyridinyl]oxy] phenoxy]propanoic acid\}), paraquat (1,1'-dimethyl-4,4'bipyridinium ion), and glyphosate ( $\mathrm{N}$-(phosphonomethyl)glycine). Glyphosate is an excellent general-purpose postemergence herbicide. Sethoxydim and fluazifop are selective postemergence herbicides, especially used to control perennial grasses such as bermudagrass, torpedograss, johnsongrass, and guineagrass (Retzinger \& Rogers, 1982; Winton \& Frans, 
1984; Barrentine \& McWhorter, 1988).

Recommended herbicidal application rates (active ingredient/treated acre) to control weedy grasses are as follows: bromacil or diuron at 1.6-3.2 lb, norflurazon at 2.4-4.0 lb, oryzalin at $2.4 \mathrm{lb}$, oxyfluorfen at $0.5-2.0 \mathrm{lb}$, simazine at 2.25-3.96 lb, thiazopyr at $0.13-0.50$ $\mathrm{lb}$, sethoxydim at $0.38-0.47 \mathrm{lb}$, fluazifop-butyl at $0.25-0.38 \mathrm{lb}$, paraquat at $0.63-0.94 \mathrm{lb}$, and glyphosate at 1.0-4.0 lb (Tucker \& Singh, 1993; Futch, 1997; Futch et al., 1999).

\section{Need for An Alternative Technology for Control of Weedy Grasses}

The citrus growers depend on herbicides because chemical weed control is effective. This has led to environmental concerns such as groundwater contamination and resistance of weeds to most of the herbicides that are registered for use. There is potential for toxicity to citrus by some herbicides. Toxicity is influenced by rootstock, age of trees, and nature of soil type (sandy soils with shallow root systems of young trees). Differences in absorption, translocation and metabolism of herbicides contribute to the differential susceptibility of one weed species over the other (Tamma \& Singh, 1987).

There were 48 species of triazine-resistant weeds worldwide, of which 35 were broadleaf and 13 were grass species (Johnson \& Coble, 1986). As of 1997 (Heap, 1997), 150 resistant grass and broadleaf weed biotypes have been recorded in about 50 countries worldwide. Most cases of herbicidal resistance are due to repeated use over several years, long residual activity, and single dominant site of action. In areas, where herbicidal resistance has developed, a few resistant biotypes occur naturally, and through selective pressure exerted by a herbicide, these biotypes eventually dominate the population. 
The weak point of conventional weed management is its chemical-dependency. This leads to excessive chemical input and increasing cost of crop production. The environmental consequences make conventional weed management ecologically and socially unsustainable. Therefore, chemical herbicide technology in weed management needs refinement to become sustainable (Mersie \& Singh, 1989). This can be achieved by elimination of environmental impacts from chemical herbicides without loss of weed-control effectiveness. Application efficiency of existing chemical herbicides can be enhanced by means of chemical injection via low-volume micro-sprinkler irrigation systems and by mowing/wiping with low doses of postemergence herbicides. Adjuvants can be used to increase foliar penetration, inhibit leaching of herbicide in soil, and to broaden the spectrum of weeds controlled. Selective spraying of herbicides on to target weeds can be done using either weed detectors or other expert technologies. Use of controlled-release formulations can possibly reduce total input of herbicides into the environment. Nonchemical weed control methods can be deployed in an integrated approach to enhance effectiveness and sustainability of weed-management practices.

\section{Bioherbicidal Technology for Weed Management}

Biological weed control is an alternative means of weed management. It can supplement existing conventional technologies for weed control. Biological control of selected weeds is being practiced under field conditions in crops such as rice, soybean, and citrus (Charudattan, 1991). In the United States, there are several successful examples of weed control using host-specific fungal plant pathogens on a practical or experimental scale. For example, hamakua pamakani weed (Ageratina riparium Regel) is controlled in Hawaii 
by Entyloma compositarum Farl. (Trujillo et al., 1988), milkweed vine (Morrenia odorata (H. \& A.) Lind1.) by Phytophthora palmivora (E.J. Butler) E.J. Butler (Kenney, 1986; Ridings, 1986), musk thistle (Carduus nutans L.) by Puccinia carduorum Jacky (Baudoin et al., 1993), northern jointvetch (Aeschynomene virginica (L.) B.S.P.) by Colletotrichum gloeosporioides (Penz.) Penz. \& Sacc. in Penz. f. sp. aeschynomene (Daniel et al., 1973), sicklepod (Senna obtusifolia (L.) Irwin \& Barneby) by Alternaria cassiae Jurair \& Khan (Walker \& Boyette, 1985; Charudattan et al., 1986), skeletonweed (Chondrilla juncea L.) by Puccinia chondrillina Bubak \& Syd. (Supkoff et al., 1988), yellow nutsedge (Cyperus esculentus L.) by Puccinia canaliculata (Schwein.) Lagerh. (Phatak et al., 1983), and waterhyacinth (Eichhornia crassipes (Mart.) Solms) by Cercospora rodmanii Conway (Charudattan et al.,1985; Charudattan, 1986). In 1990, about 45 species of fungi were reported to be under evaluation or development in 19 countries and 44 locations against about 65 weeds (Charudattan, 1990). Included were 14 of the top 18 worst weeds in the world, and several others of regional and specific importance. Most of the target weeds were broad-leaved weeds and there are no biological control agents currently available to control weedy grasses.

In nature, numerous pathogens on indigenous plants, including weeds, rarely cause major epidemics. Host, pathogen, and environmental factors contribute to constraints on disease development (isolation of host and pathogen over space and in time, inadequate inoculum for disease to build up to destructive levels, and unfavorable environmental conditions). Such constraints can be overcome by applying a higher dose of inoculum, when the plant is most susceptible, and when environmental conditions are favorable for disease development. This approach can lead to a rapid epidemic. In this regard, indigenous 
plant pathogens are suitable since they can be developed and used as bioherbicides (Charudattan, 1990). Unlike obligate parasites that are biotrophic (which do not kill the host or host tissues in advance, but rather grow in the host in intricate association with the host's cytoplasm), necrotrophic pathogens kill host tissue in advance of parasitism (they must derive their energy from the dead host cells). Such necrotrophs are highly suitable candidates as bioherbicides, because they can rapidly kill an entire plant or plant parts. Also, necrotrophs produce various phytotoxic metabolites and lytic enzymes as their first line of attack against the host.

A bioherbicide is a plant pathogen, commonly a fungal or bacterial pathogen often used in an inundative biological control strategy. Fungal pathogens are the most commonly used bioherbicidal agents. The pathogen is mass-cultured, formulated, standardized, and applied pre- or post-emergence when the weeds are at a susceptible growth stage (Charudattan, 1988a). A bioherbicide is composed of active ingredients such as spores, cells, or mycelial fragments of the pathogen, and inactive ingredients such as diluents, spreaders, and stickers that increase the efficacy of the pathogen (Connick, et al., 1990). Once a candidate bioherbicide is developed through basic research and testing, it must then be manufactured, standardized, packaged, and registered by the U. S. Environmental Protection Agency (EPA). Bioherbicides are applied with conventional tools used to apply chemical herbicides. They can provide rapid and complete weed control similar to the fast-acting chemical herbicides. There is usually a need for annual applications, since the pathogen may not survive in sufficient numbers, and may not multiply during inter-crop seasons. Thus, there would not be sufficient inoculum to incite a fresh epidemic on new weed infestations. 
Bioherbicides have some disadvantages: 1) typically, bioherbicides are highly hostspecific and therefore a single bioherbicidal pathogen causes disease on only one specific weed host, 2) they provide incomplete or insufficient level of weed control as compared to that achieved by using chemical herbicides, and 3) incompatibility of bioherbicides with conventional chemical herbicides. An extreme level of host-specificity is a disincentive for commercialization of a bioherbicidal agent. Previously developed bioherbicides typically controlled only one of a spectrum of weeds that required control. The narrow range of weed control can be overcome with 1) a mixture of host-specific pathogens that are compatible in a tank-mix and possess similar requirements for disease development or by 2) tank-mixing host-specific pathogens with a lower-than-normal dose of a broad-spectrum herbicide compatible with the bioherbicidal agent. Hypothetically, it is feasible to develop a "Multiple-Pathogen Strategy" using three or more host-specific pathogens that are combined and applied inundatively to simultaneously control several weeds (Chandramohan \& Charudattan, 1996). The level of weed control is enhanced by using a mixture of pathogens rather than a single pathogen. If one of the pathogens in the mixture fails, the others may compensate. Also, the use of a pathogen mixture may reduce the chances of development of resistance in weed hosts to a single pathogen. In addition, it is possible to take advantage of synergistic interactions that may occur among pathogens in the mixture, which will enhance the efficacy of the bioherbicidal mixture, than when applied alone. The level of weed control can be improved with repeated applications.

Bioherbicidal agents may be not compatible in tank mixes with herbicides. Effective integration can be realized by a careful sequential application of the bioherbicide (Smith, 1982; 1991). Each bioherbicide and chemical pesticide interaction can be studied to develop 
a set of recommendations for their effective use in an integrated, weed-management system. There are also ways to improve a bioherbicidal agent's tolerance of pesticides by genetic engineering, and thus, improve the usefulness of the bioherbicidal strategy (Sands et al., 1990; Charudattan et al., 1996).

Whatever the level of disease severity obtained by the bioherbicidal pathogens, the only characteristic that the user of the strategy is likely to appreciate is the amount of weed control obtained. Because bioherbicides will have to compete with chemical herbicides in the market place, the public expectation of bioherbicidal efficacy will be conditioned by their experience with chemical herbicides. Chemicals are known for their cost-efficiency, effectiveness, ease of application, speed of control, and predictability of results. A expectation for a comparable type of efficacy for bioherbicides may limit the number of pathogens that can succeed in the marketplace. Some pathogens cause subtle effects on the physiology of the infected weed, reducing its growth, reproduction and competitiveness. In these cases, there may not be complete killing of weeds, but suppression of weeds sufficient to render the weeds less-competitive with the crop (Charudattan, 1988b). Educational programs may need to be established to provide this type of information.

\section{Enhancement of Field Efficacy of Bioherbicides}

A major constraint to the development and marketing of bioherbicides is the requirement for appropriate formulations to facilitate storage, handling, and successful performance of the bioherbicidal agent in the field (Auld, 1992; Baker \& Henis, 1990; Greaves \& Macqueen, 1990; Rhodes, 1990). Formulation of bioherbicides is the blending of the active ingredient, the biological propagule, with a carrier, adjuvant or diluent to 
produce a product form that can be effectively delivered to the target weed (Boyette et al., 1991a; Rhodes, 1990). The efficacy of the agent as well as placement, and application timing are critical (Fravel \& Lewis, 1992). Therefore, the formulation has to be compatible with the agent, enhance its performance, and preferably be compatible with conventional agricultural practices with regard to method and timing of application (Greaves \& Macqueen, 1990; Powell, 1992; Rhodes, 1990). Also, the formulation should be safe, easy to use, and maintain the viability of the agent during storage, distribution and application (Leggett \& Gleddie, 1995).

Formulation is crucial to enhance the efficacy of a bioherbicide (Green et al., 1998). It can help overcome environmental constraints such as dew requirements (most fungal plant pathogens used as bioherbicides require free water or an extended dew period for optimal infection and disease development) (Auld, 1992; Connick et al., 1990). Formulation can increase shelf life, enhance stability and biological activity of the agent, predispose the target weed to infection, interfere with host defenses in the target weed, and reduce concentration of propagules required for field-application (Amsellem et al., 1991; Auld, 1992, Boyette et al., 1991a; Burge, 1998). The materials in a formulation may also stimulate the germination of fungal spores (Winder \& Van Dyke, 1990), enhance virulence of the agent (Bothast et al., 1993), allow adequate spread of the inoculum over the leaf surface while preventing wash-off by rain, protect the bioherbicidal agent against ultraviolet radiation in intense sunlight, enable easier application of the propagules with conventional spray equipment, or a combination of these features (Greaves \& Macqueen, 1990). 
The type of formulation used for a bioherbicide depends upon the type and mode of action of the pathogen, and available application technology. Most formulations of bioherbicides are largely based upon techniques developed for formulation of agrochemicals (Rhodes, 1990). This involves the use of organic solvents, surfactants, and drying methods, all of which can be detrimental to biological propagules (Connick et al., 1991a). Connick et al. (1991a) suggested that the formulation procedures used in the food industry can be adapted in formulating bioherbicides. These include the use of alginate and invert emulsions. Liquid formulations include aqueous-, oil-, or polymer-based products, and are used as postemergence sprays as an aid to incite leaf and stem diseases on the weed host (Boyette et al., 1991a). The simplest delivery system for a bioherbicide contains the propagules of the agent formulated as a sprayable suspension in water (Connick et al., 1990; Hofmeister \& Charudattan, 1987). This formulation is used mostly in the early stages of evaluation of a bioherbicidal pathogen (Daigle \& Connick,1990). Recently, oil emulsions (oil-in-water) and invert emulsions (water-in-oil) have been used to enhance bioherbicidal efficacy (Auld, 1993; Boyette, 1994; Egley \& Boyette, 1995; Womack et al., 1996).

In the case of foliar-applied bioherbicides, the propagule remains on the leaf surface after application and is exposed to rain, abrasion, ultraviolet radiation and desiccation, all of which can reduce its viability (Greaves \& Macqueen 1990; Rhodes 1990). Many bioherbicidal agents require a 6 to $24 \mathrm{~h}$ period of free water (dew period) for propagules to germinate and penetrate the host (Auld, 1992; Auld \& Morin, 1995; Connick et al., 1990). This requirement of free moisture is a very critical factor in biological weed control (Fernanado et al., 1994). Therefore, application timing has to coincide with moist and humid 
environmental conditions (Klein \& Auld, 1995). Formulations have to help protect the agent until host penetration is complete (Baker \& Henis, 1990; Rhodes, 1990; Winder, 1990; Winder \& Watson, 1990), and increase the window for optimum timing of application.

An adjuvant is a compound which assists or modifies the action of a principal active ingredient (Foy, 1989). Various adjuvants have been included in bioherbicidal formulations to improve or modify propagule germination, pathogen virulence, or reduce environmental requirements of the agent, to overcome host resistance factors, and assist in delivery (Boyette et al., 1991a; Womack \& Burge, 1993). Since environmental factors such as dew period, ultraviolet radiation, and heat, and drought conditions greatly influence bioherbicidal efficacy, adjuvants that can minimize the undesirable effects of these factors are important for successful bioherbicidal formulations (Prasad, 1993; 1994; Watson, 1989). Adjuvants may also provide more efficient distribution of the agent and help to retain the physical integrity and stability of the formulation during application (Rhodes, 1990).

Adjuvants encompass a wide range of compounds. Many adjuvants suitable for inclusion in chemical herbicide formulations may not be suitable for bioherbicide formulations. Adjuvants, such as surfactants, anti-evaporation agents, spreaders, stickers, humectants, and sunscreen agents were evaluated by Prasad $(1993 ; 1994)$ and many were found to inhibit in vitro growth of the bioherbicidal agent, Chondrostereum purpureum Fr. Pouzar. Grant et al. (1990) evaluated 16 adjuvants for their effects on spore germination of Colletotrichum gloeosporioides (Penz.) Penz. \& Sacc. in Penz. f. sp. malvae. Adjuvants such as Renex 36 (tridecyl- $\Omega$-hydroxypoly(oxy-1,2-ethanediol)) and Triton XR \& X-77 ( $p$ ( $\Omega$-Octylphenyl)- $\Omega$-hydroxypoly(oxy-1,2-ethanediol)) inhibited spore germination. None 
of the adjuvants increased spore germination compared to spores in water only. Winder and Van Dyke (1990) tested six adjuvants for their effect on disease severity caused by the fungal agents Bipolaris sorghicola (Lefebvre \& Sherwin) Alcorn and an unidentified Bipolaris species on johnsongrass (Sorghum halepense (L.) Pers.). They were oxysorbic polyoxyethylene sorbitan monolaurate (OPSM) (0.2\%), oxysorbic polyoxyethylene sorbitan monooleate $(0.2 \%)$, vegetable oil ( $1 \%)$, glycerol $(1 \%)$ plus OPSM $(0.2 \%)$, glycerol $(1 \%)$ plus vegetable oil (1\%), and polyglycol ether $(0.2 \%)$. Vegetable oil was the best adjuvant in these cases and it appeared to stimulate spore germination as well.

Other adjuvants studied included sucrose (Walker, 1980), Soy Dex (Winder \& Van Dyke, 1987), sorbitol (Wymore \& Watson, 1986), pregelatinized starch and casaminoacids (Bothast et al., 1993; Schisler et al., 1995), proteins (Fravel et al., 1985; Winder \& Watson, 1990), pectins and pectinase (Boyette, 1987), xanthan gum (Cardina \& Littrell, 1986), and salts (Stowell et al., 1987; Winder \& Watson, 1990).

It is necessary to protect the propagules of a bioherbicidal agent after they are sprayed in liquid-based formulations onto weeds. Invert emulsions can help overcome desiccation. An invert emulsion consists of water suspended in oil, in contrast to a standard emulsion, in which oil is suspended in water (Boyette et al., 1991a). Invert emulsions retard evaporation and trap water in the spray mixture so that the propagules are held in water droplets protected within an oily matrix (Boyette et al., 1993, Connick et al., 1991b; Daigle et al., 1990, Womack \& Burge, 1993; Womack et al., 1996). Also, invert emulsions may improve adhesion of inoculum to the host surface (Munyaradzi et al., 1990). 
Invert emulsions that contain various kinds of oils have been tested and found to reduce dew requirements and enhance efficacy of a bioherbicidal agent. Quimby et al. (1988 a,b) used soybean lecithin, paraffinic oil, paraffinic wax, and soybean oil. Boyette et al. (1993) used paraffinic oil , a monoglyceride emulsifier, paraffinic wax, lanolin, and spores in water mixed with the oil phase at a ratio of 2:3. Munyaradzi et al. (1990) used soybean oil $(2.8 \mathrm{ml})$, soybean lecithin $(1.2 \mathrm{ml})$, paraffin wax $(0.5 \mathrm{ml})$, paraffin oil $(2.8 \mathrm{ml})$, sodium alginate ( $10 \mathrm{ml}$ of a $0.25 \%$ solution), and spores in water to make up a total vol of $20 \mathrm{ml}$. Amsellem et al. (1990) used soy lecithin (120 g), soybean oil (550 ml), mineral oil (280 ml), paraffin wax $(50 \mathrm{~g} / \mathrm{L})$ in the oil phase, and $0.5 \%$ sodium alginate in the water phase that contained spores. Daigle at al. (1990) used paraffin wax, soybean lecithin, paraffin oil, soybean oil, and a heavy mineral oil mixed with an aqueous phase containing $0.25 \%$ sodium alginate and $0.5 \% \mathrm{Ca}(\mathrm{OH})_{2}$.

There are several disadvantages associated with invert emulsion formulations. Invert emulsions are highly viscous. This high level of viscosity makes it difficult to apply these emulsions with conventional spray equipment. Some components of the oil phase can also be phytotoxic to certain plants (Auld, 1993; Boyette, 1994; Womack \& Burge, 1993). Connick et al. (1991b) developed an improved invert emulsion with an unsaturated monoglyceride (Myverol 18-99) as the emulsifier instead of soybean lecithin. This formulation had lower viscosity and higher water-retention capacity. Yang et al. (1993) developed a similar invert emulsion formulation with Orchex oil that had negligible phytotoxicity to the weed host and could be easily applied. Advances in formulation techniques are important to the continued development of bioherbicides (TeBeest, 1996). The formulation must reduce environmental dependency of a bioherbicidal agent, mainly for 
free moisture. Invert emulsions allowed infection by bioherbicidal fungi to occur in the absence of available free moisture in several experiments conducted with different potential bioherbicides (Boyette et al., 1993, Connick et al., 1991a,b; Daigle et al., 1990, Womack \& Burge, 1993, Womack et al., 1996; Yang et al., 1993; Yang \& Schaad, 1998).

Recently, two fungal pathogens, Phomopsis amaranthicola sp. nov. host-specific to the genus Amaranthus (pigweed) and amaranths and Dactylaria higginsii (Luttrell) M.B. Ellis, specific to Cyperus (nutsedges) have been evaluated in the field (Rosskopf, 1997; Kadir, 1997). The following fungal plant pathogens have been reported to have the potential for development as bioherbicides to control some of the weedy grasses although none have reached commercial status as registered products: Sphacelotheca holci Jack. $[=S$. cruenta (Kuhn.) Potter] for johnsongrass (Massion \& Lindow, 1986); Bipolaris setariae (Saw.) and Pyricularia grisea (Cke.) Sacc. for goosegrass (Figliola et al., 1988); Exserohilum turcicum (Pass.) Leonard \& Sugg., Colletotrichum graminicola (Ces.) G.W. Wils., Gleoocercospora sorghi Bain \& Edgerton and Bipolaris halepense Chiang, Leonard and Van Dyke for johnsongrass (Chiang et al., 1989a,b); Bipolaris sorghicola (Lefebvre \& Sherwin) Alcorn and an unidentified species of Bipolaris for johnsongrass (Winder \& Van Dyke, 1990); and Exerohilum monoceras (Drechs.) K.J. Leonard \& E. G. Suggs for Echinocloa spp. (Zhang \& Watson, 1997a). The fungal pathogens of johnsongrass were not developed further due to lack of consistent efficacy and difficulty in mass production of the inoculum. Since there are no bioherbicides available to control weedy grasses, the development of a bioherbicide or bioherbicides is considered to provide a nonchemical option for the management of weedy grasses. 
The objectives of this study were to (1) discover, identify, and evaluate efficacy and host range of indigenous fungal plant pathogens that could be developed as bioherbicides to control several weedy grasses, (2) develop and test a "Multiple-Pathogen Strategy" for bioherbicidal control of several weeds and to study host-specific responses of pathogens in a mixture on different weed hosts, (3) develop a technique to mass produce fungal inoculum for field studies, (4) field-test the "Multiple-Pathogen Strategy" for bioherbicidal control of several weedy grasses, and (5) field-test the pathogen mixture for bioherbicidal control of a natural population of guineagrass, a major weed in citrus in Florida. 


\section{CHAPTER II \\ A MULTIPLE-PATHOGEN STRATEGY FOR BIOHERBICIDAL CONTROL OF SEVERAL WEEDS}

\section{Introduction}

Bioherbicides may be developed from indigenous organisms that are normally restrained in nature from causing epidemics on weed hosts and are easily culturable (Templeton, 1982; Templeton et al., 1979). Although a plant may be affected by several pathogens, not all may have equal potential to be developed as bioherbicides. It is possible to estimate the potential of a given pathogen with knowledge of its disease cycle or hostparasite relationship, and from knowledge gained from literature on similar pathogens of economic crops where more information is available (Shrum, 1982; Smith et al., 1973). Daniel et al. (1973) list three general requirements to select potential bioherbicides: the pathogen must 1) be able to produce abundant and durable inoculum in artificial culture, 2) be genetically stable and specific for the target weed, and 3) be able to kill the weed in wide range of environmental conditions.

Disease development depends on host susceptibility, pathogen virulence, and favorability of environment. Any of the three components may favor the host and suppress the pathogen, and thus suppress disease to low levels (Holcomb, 1982). In the selection of potential biological control agents to be developed as bioherbicides, it is prudent to select a pathogen that will be specific to the target weed host, and also have ample virulence to kill 
plants or potential to cause high severity of disease, when the pathogen's inoculum is applied inundatively (Shrum, 1982).

The advantage of the bioherbicidal technology is that the pathogen may be applied at anytime when environmental conditions are suitable for disease onset (proper timing of inoculation) and also whenever the weeds are in susceptible stage to the pathogen (stage of weed growth). In this technology, inoculum of a candidate pathogen is mass cultured, standardized, formulated, and applied to weeds (Charudattan, 1991). It has potentially wide commercial application in agriculture.

Daniel et al. (1973) demonstrated that an endemic pathogen might be rendered completely destructive to its weed host when a massive dose of inoculum is applied at a particular susceptible stage of weed growth, and when environmental conditions are favorable for disease development. The application of an inundative dose of inoculum would bypass the period for inoculum buildup and pathogen distribution that are essential for natural epiphytotics (Charudattan, 1991). The pathogen can be applied annually shortly after the emergence of the weed, and when conditions for disease development are favorable.

Constraints to the development of bioherbicides include: finding a pathogen strain with adequate level of virulence, destructiveness, and host-specificity, possible incompatibilty of the strain with chemical herbicides, technical difficulties in inoculum production and product development, competition from chemical herbicides, and economic considerations dictated by the market place. Most of these constraints may be overcome with different levels of ease or difficulty. However, unless a bioherbicide is fairly fastacting, affords high levels of weed control similar to chemical herbicides, and is easy to use and predictable in performance, it is difficult to expect acceptance by industries and users 
(Charudattan, 1990).

In situations where bioherbicides are to be used in combination with chemical pesticides, viability and efficacy of the biological agents may be adversely affected by the chemicals. For example, in cases where fungicides are used for disease control, a bioherbicide has been adversely affected (Smith, 1982 \& 1986). This problem can be overcome with a careful sequencing of fungicide and bioherbicidal applications. Some of the bioherbicidal pathogens may be compatible with certain chemical pesticides. Each interaction of a bioherbicide and a chemical pesticide must be studied to develop a set of recommendations for their effective use. Pesticide-tolerant strains of the pathogen may be produced by genetic engineering of the agent. The feasibility to improve bioherbicidal pathogens with genetic engineering has received attention (Charudattan, 1985; Turgeon \& Yoder, 1985; Greaves et al., 1989; Templeton \& Heiny, 1989; Templeton, 1990). Use of recombinant DNA technology may offer a precise and directed approach to enhance effectiveness and modify host-specificity of pathogens as demonstrated by Charudattan et al. (1996).

DeVine $^{\star}$ (Phytophthora palmivora (E.J. Butler) E.J. Butler used to control milkweed vine, Morrenia odorata (H. \& A.) Lindl. in citrus), and Collego (Colletotrichum gloeosporioides (Penz.) Penz. \& Sacc. in Penz. f.sp. aeschynomene to control northern jointvetch, Aeschynomene virginica (L.) B.S.P. in rice) are among the bioherbicides registered for commercial use in the United States. Each of them is used to control a single weed species. Plant pathogens with a narrow host range and efficacy to control more than one weed host are available for further development (e.g., Alternaria cassiae, a pathogen of sicklepod (Senna obtusifolia (L.) Irwin \& Barneby), coffee senna (Senna occidentalis L.), 
and showy crotalaria (Crotalaria spectabilis L.)) (Charudattan, 1988a; Walker, 1983; Walker \& Boyette, 1985).

\section{"Multiple-Pathogen Strategy"}

The major disadvantages of currently available bioherbicides are their hostspecificity and insufficient level of weed control. These bioherbicides often affect only one or a small group of weed species. It is rare to find a pathogen that will attack more than one economically important weed species and yet be safe for use. Narrow host-specificity of a bioherbicide would therefore preclude its use to control a broad spectrum of weeds in a crop. However, this problem can be overcome by using mixtures of microorganisms. Boyette et al. (1979) showed that a mixture of Colletotrichum gloeosporioides (Penz.) Penz. \& Sacc. in Penz. f.sp. aeschynomene and C.gloeosporioides f.sp. jussiae could simultaneously control northern jointvetch (Aeschynomene virginica) and winged waterprimrose (Jussiaea decurrens (Walt.) DC). Synergistic interactions may occur and pathogens applied in mixtures might enhance the level of host damage. Hallet et al. (1990) reported that synergistic interactions (expressed as increased disease severity) between rust fungi and secondary invaders may be widespread and may possibly be exploited in the biological control of weeds. Such synergistic interactions can be influenced by various inoculum concentrations, inoculum ratios, host age, and optimal temperature and dew requirements.

Measurement of efficacy of a bioherbicide includes the level of weed control provided by the agents as well as the speed and ease with which the control is accomplished (Charudattan, 1988b). The efficacy of bioherbicides may be enhanced by combining a mixture of host-specific pathogens. Increased bioherbicidal activity can occur due to 
synergism among pathogens. These pathogens may act complementarily and compensate for any loss of efficacy of individual agents. Even in the absence of synergism, fungal pathogens that are not antagonistic to one another can be used simultaneously to control a broad-spectrum of weeds. The use of a pathogen mixture may also help overcome development of resistance in a host to one of the pathogens. It is possible to develop a "Multiple-Pathogen Strategy" using three or more host-specific pathogens combined and applied inundatively to control three or more weeds. The bioherbicidal mixture could be applied as a postemergent spray or by preemergent soil incorporation under optimal environmental conditions (in relation to each host-pathogen system) to achieve maximum bioherbicide efficacy.

\section{Host-Specific Fungal Plant Pathogens}

In this study, a pathogen mixture consisting of four pathogens was tested. The pathogens were: Alternaria cassiae Jurair and Khan; major host, sicklepod (Senna obtusifolia (L.) Irwin \& Barneby) and alternative host, showy crotalaria (Crotalaria spectabilis Roth.); Colletotrichum dematium (Penz.ex Fr.) Grove f.sp. crotalariae and Fusarium udum (Butler) f.sp. crotalariae (Kulkarni) Subramanian, pathogens of showy crotalaria, and Phomopsis amaranthicola Rosskopf, Charudattan, Shabana \& Benny, a pathogen of pigweeds (Amaranthus spp.) including Amaranthus hybridus L..

Alternaria cassiae is a dematiaceous hyphomycetous fungus originally isolated from Cassia holsericea Fresen. in Pakistan. The same species was found on sicklepod (Senna obtusifolia) in southern United States and Brazil (Walker, 1982; Barreto and Evans, 1992). This pathogen causes very rapid and extensive necrosis of hypocotyls, cotyledons, epicotyls, 
and true-leaves of sicklepod seedlings. Inoculated sicklepod seedlings develop brownishblack lesions within $24 \mathrm{~h}$ of inoculation (Figure 2-1.A). These lesions coalesced and eventually the entire seedling turned necrotic (Van Dyke \& Trigiano, 1987).

Colletotrichum dematium f.sp. crotalariae causes an anthracnose disease on young seedlings of showy crotalaria. Inoculated seedlings display foliar lesions originating in the petiole and expanding into the leaf lamina and stem 5 days after inoculation (Figure 2-1.B). This is followed by total defoliation and eventual death of the seedling. Fusarium udum f.sp. crotalariae invades the roots of showy crotalaria and causes epinasty, interveinal chlorosis, and eventual wilting of plants (Figure 2-1.C). Phomopsis amaranthicola sp. nov. causes a leaf and stem blight on pigweed, Amaranthus L. spp. The disease begins as foliar lesions that coalesce and expand to the leaf petiole, causing premature leaf abscission. Symptoms on the foliage appear within 1 week after inoculation. The disease progresses with lesions girdling the stem (Figure 2-1.D), eventually toppling the whole plant (Rosskopf, 1997). Alternaria cassiae, C. dematium f.sp. crotalariae, and P. amaranthicola cause high levels of disease on their respective host plants within 1-4 weeks after inoculation, while $F$. udum is a slow-acting root-pathogen.

The objectives of this study were to i) test the feasibility to control several weeds with a mixture of pathogens in a "Multiple-Pathogen Strategy", ii) determine the bioherbicidal efficacy of the abovementioned pathogens alone and in mixture, and iii) observe for host-specific response of individual pathogens applied as a mixture on the different weed hosts. 

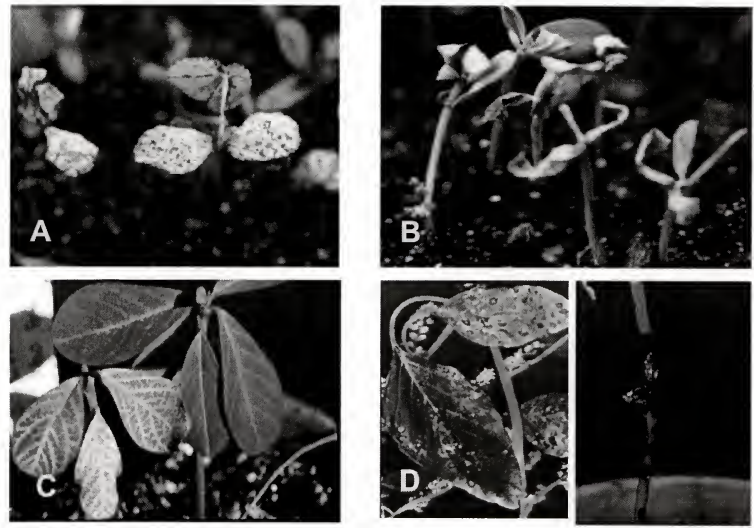

Figure 2-1. Disease symptoms caused by the host-specific fungal pathogens Alternaria cassiae on sicklepod (A), Colletotrichum dematium f.sp. crotalariae on showy crotalaria (B), Fusarium udum f.sp. crotalariae on showy crotalaria (C), and Phomopsis amaranthicola on pigweed (D). 


\section{Materials and Methods}

\section{Seedling Production}

Seeds of pigweed, sicklepod, and showy crotalaria purchased from Valley Seed Services, Fresno, California were planted in flats in the greenhouse. Seedlings were transplanted at the cotyledon stage ( 6 seedlings per weed species per 15 -cm-diam x 15.63 cm-tall pot containing a commercial potting medium (Metromix 300; Scott's-Sierra Horticultural Products Co., Marysville, Ohio)). The seedlings were allowed to grow until they reached the 4- to 6- leaf stage.

\section{Inoculum Production}

A conidial preparation of A. cassiae provided by Mycogen Corp., San Diego, CA (CASST, Mycogen MYX-104 100\% WP, EPA Experimental Use Permit No: 53219-EUP-1) was used. The conidia were readily suspended in deionized water and then standardized. Cultures of $P$. amaranthicola were initiated on plates of modified V8 agar (200 $\mathrm{ml} \mathrm{V8-juice,}$ $14 \mathrm{~g}$ agar, Dhingra and Sinclair, 1995) using a mycelial plug from a stock culture. The V8 plates $\left(100 \times 15 \mathrm{~mm}\right.$ petri dish) were incubated for $1-2$ weeks $\left(25^{\circ} \mathrm{C}, 12 \mathrm{~h} / 12 \mathrm{~h} \mathrm{light} /\right.$ dark, $35 \pm 5 \mu \mathrm{E} / \mathrm{m}^{2} / \mathrm{s}$ ), until conidial ooze was observed on pycnidia that formed in concentric circles on the agar surface. A loopful of the conidial ooze was aseptically transferred to fresh V8 agar and streaked across the surface of the agar several times. The plates were incubated as before for 2 weeks. To prepare conidial suspensions, conidia were harvested from V-8 agar plates after each plate was flooded with $10 \mathrm{ml}$ of deionized water and the spores dislodged with a rubber spatula. The suspension was then filtered through two layers of cheesecloth. Cultures of $C$. dematium f.sp. crotalariae were initiated on PDA using a 
mycelial plug from stock culture, and the PDA plates (100x $15 \mathrm{~mm}$ petri dish) were incubated for 1 week $\left(25^{\circ} \mathrm{C}, 12 \mathrm{~h} / 12 \mathrm{~h}\right.$ light $/$ dark, $\left.35 \pm 5 \mu \mathrm{E} / \mathrm{m}^{2} / \mathrm{s}\right)$. The conidia were harvested in the same manner as for $P$. amaranthicola. Microconidia of $F$. udum $\mathrm{f}$. sp. crotalariae were produced in shake-cultures. A mycelial plug from the stock culture was used to inoculate potato dextrose broth (PDB) in Fernbach flasks (250 ml PDB / $2 \mathrm{~L}$ flask). After 48-72 h of shake-culturing at $150 \mathrm{rpm}$, the conidia were harvested as in the case of $P$. amaranthicola. The concentration of spores was determined with a haemocytometer, and the spore suspension was adjusted to the desired concentration by dilution in water.

\section{Evaluation of "Multiple-Pathogen Strategy" for Bioherbicidal Control of Several Weeds}

A spore suspension of each pathogen alone $\left(10^{6}\right.$ per $\left.\mathrm{ml}\right)$ and a cocktail of the four pathogens (1:1:1:1 by vol.) containing $10^{6}$ spores per $\mathrm{ml}$ were tested on the weed seedlings that were grown together in pots. The inoculum suspensions as well as the control (water only) were amended with $0.5 \%$ Metamucil $^{\circledR}$ (Procter \& Gamble, Cincinnati, OH). The seedlings were sprayed until runoff, provided $12 \mathrm{~h}$ of dew in dew chambers maintained at $28^{\circ} \mathrm{C}$, and then moved to a greenhouse. The inoculated seedlings were evaluated for disease development at 1,4 , and 6 weeks after inoculation. Disease incidence (DI) was recorded as the proportion of diseased plants, and disease severity (DS) was recorded as the proportion of diseased area of a plant. Mortality was recorded as proportion of fully dead seedlings. A completely randomized experimental design was used and the experiments were done twice. 


\section{Electron Microscopic Study of Host-specific Response of Pathogens in A Mixture}

Specimens of leaf and stem tissues were collected (24-48 $\mathrm{h}$ after inoculation) from all treatments for each of the three weeds from the experiment mentioned above. The tissue specimens were subjected to scanning electron microscopy (SEM) as follows: The tissue samples were exposed to $1 \%$ osmium tetroxide vapor until the tissue turned black (overnight). (Osmium tetroxide was placed in one compartment of a petri dish (100x15 mm petri dish having four compartments) and individual tissue specimens were placed in separate compartments). The specimens were then passed through an ethanol series by sequential immersion in changes of $25 \%, 50 \%, 75 \%, 95 \%$, and $100 \%$ ethanol. At every change, the specimens were in the alcohol treatments for 15-20 min and all the specimens went through the whole series twice. The specimens were then critical-point dried (Balzers Critical-Point Drier, Germany) to replace the ethanol in the specimens by passing liquid $\mathrm{CO}_{2}$ over the samples several times, until all the ethanol was removed. The liquid $\mathrm{CO}_{2}$ was passed four times. The specimens were in liquid $\mathrm{CO}_{2}$ for 20 min each time. Then, the specimen chamber was heated to $37^{\circ} \mathrm{C}$. When the temperature and pressure inside the specimen chamber reached $31^{\circ} \mathrm{C}$ and 73.9 bars respectively, liquid $\mathrm{CO}_{2}$ is converted into gaseous phase without any transient phase (absence of surface tension). This allows the specimens to maintain structural integrity. The specimens were mounted individually on metallic stubs and sputter-coated with gold using an IB2 Ion Coater (Eiko Engineering, Japan), and then observed with a Hitachi S-4000 FESEM, Field-Emission Scanning Electron Microscope. 


\section{Results}

Effect of Multiple-Pathogen Inoculation on the Bioherbicidal Control of Sicklepod, Showy Crotalaria, and Pigweed

Alternaria cassiae, C. dematium f.sp. crotalariae, and P. amaranthicola caused extensive damage to their specific weed hosts, when inoculated either alone or in a mixture (Table 2.1, Figures 2.2, and 2.3). At 1 week after inoculation, sicklepod and showy crotalaria had $100 \%$ disease incidence, $100 \%$ disease severity and $100 \%$ mortality, when inoculated with $A$. cassiae alone and with the fungal mixture. Showy crotalaria inoculated with C. dematium f.sp. crotalariae alone and the fungal mixture had $100 \% \mathrm{DI}, 100 \% \mathrm{DS}$, and $100 \%$ mortality. Pigweed developed foliar lesions and $100 \%$ DI 1 week after inoculation, 100\% DS 4 weeks after inoculation, and 100\% mortality 6 weeks after inoculation with P. amaranthicola alone and with the pathogen mixture. Showy crotalaria inoculated with $F$. udum f.sp. crotalariae alone, a root-infecting pathogen did not have any DI.

\section{Electron Microscopy of Host-Specific Response of Pathogens in Mixture}

The leaf surface of each weed host was predominantly occupied by spores of the respective host-specific pathogen (Figure 2-4 A-D). Alternaria cassiae caused extensive tissue maceration and rarely formed appressoria on sicklepod, its major host (Figure 2-6 A). It formed healthy germ tubes and multiple appressoria without any associated tissue maceration on showy crotalaria, its alternative host (Figure 2-6 B). The appressoria of $A$. cassiae lysed on pigweed, a nonhost (Figure 2-6 C). Colletotrichum dematium f.sp. crotalariae formed healthy appressoria on showy crotalaria, while either appressorial lysis 
Table 2-1. Effect of inoculation with Alternaria cassiae (AC), Colletotrichum dematium $\mathrm{f}$. sp. crotalariae (CD), Phomopsis amaranthicola (PA), Fusarium udum f. sp. crotalariae (FU), and a mixture of the pathogens (MIX, 1:1:1:1 v/v) on disease incidence, disease severity, and mortality of sicklepod (SP), showy crotalaria (SC), and pigweed (PW) species at 1,4 , and 6 weeks after inoculation (WAI).

\begin{tabular}{|c|c|c|c|c|c|c|c|c|c|c|}
\hline \multirow{3}{*}{ Pathogen } & & \multicolumn{3}{|c|}{$\%$ Incidence } & \multicolumn{3}{|c|}{$\%$ Severity } & \multicolumn{3}{|c|}{$\%$ Mortality } \\
\hline & WAI & \multicolumn{3}{|c|}{ Weed Species } & \multicolumn{3}{|c|}{ Weed Species } & \multicolumn{3}{|c|}{ Weed Species } \\
\hline & & SP & $\mathrm{SC}$ & PW & SP & $\mathrm{SC}$ & PW & SP & $\mathrm{SC}$ & PW \\
\hline \multirow[t]{3}{*}{$\mathrm{AC}$} & 1 & 100 & 100 & 0 & 100 & 100 & 0 & 100 & 100 & 0 \\
\hline & 4 & 100 & 100 & 0 & 100 & 100 & 0 & 100 & 100 & 0 \\
\hline & 6 & 100 & 100 & 0 & 100 & 100 & 0 & 100 & 100 & 0 \\
\hline \multirow[t]{3}{*}{ CD } & 1 & 0 & 100 & 0 & 0 & 100 & 0 & 0 & 100 & 0 \\
\hline & 4 & 0 & 100 & 0 & 0 & 100 & 0 & 0 & 100 & 0 \\
\hline & 6 & 0 & 100 & 0 & 0 & 100 & 0 & 0 & 100 & 0 \\
\hline \multirow[t]{3}{*}{ PA } & 1 & 0 & 0 & 100 & 0 & 0 & 50 & 0 & 0 & 0 \\
\hline & 4 & 0 & 0 & 100 & 0 & 0 & 100 & 0 & 0 & 0 \\
\hline & 6 & 0 & 0 & 100 & 0 & 0 & 100 & 0 & 0 & 100 \\
\hline \multirow[t]{3}{*}{ FU } & 1 & 0 & 0 & 0 & 0 & 0 & 0 & 0 & 0 & 0 \\
\hline & 4 & 0 & 0 & 0 & 0 & 0 & 0 & 0 & 0 & 0 \\
\hline & 6 & 0 & 0 & 0 & 0 & 0 & 0 & 0 & 0 & 0 \\
\hline \multirow[t]{3}{*}{ MIX } & 1 & 100 & 100 & 100 & 100 & 100 & 50 & 100 & 100 & 0 \\
\hline & 4 & 100 & 100 & 100 & 100 & 100 & 100 & 100 & 100 & 0 \\
\hline & 6 & 100 & 100 & 100 & 100 & 100 & 100 & 100 & 100 & 100 \\
\hline
\end{tabular}
spores per $\mathrm{ml}$, and $0.5 \%$ Metamucil $^{\circledast}$ as a humectant, at $28^{\circ} \mathrm{C}$ and $12 \mathrm{~h}$ dew. 

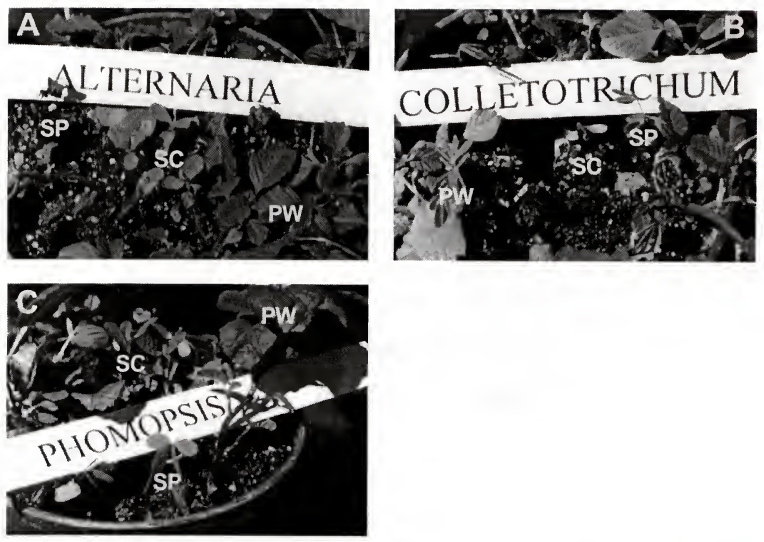

Figure 2-2. Effect of inoculation with host-specific fungal pathogens Alternaria cassiae on sicklepod (A), Colletotrichum dematium f. sp. crotalariae on showy crotalaria (B), and Phomopsis amaranthicola on pigweed (C). SP = sicklepod, $\mathrm{SC}=$ showy crotalaria, and $\mathrm{PW}$ $=$ pigweed. 

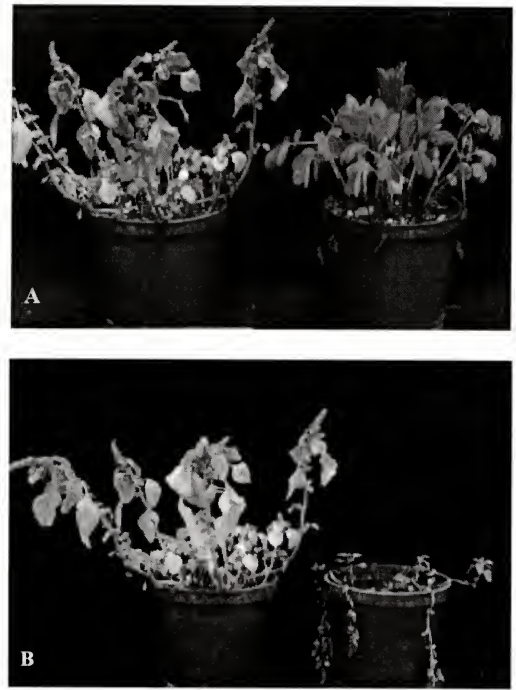

Figure 2.3. Effect of inoculation with a single host-specific pathogen and a mixture of hostspecific pathogens: control of pigweed alone with Phomopsis amaranthicola (A), and simultaneous control of all three weeds with a mixture of the pathogens (B). In each of the figures above, the pot on the left has noninoculated plants of sicklepod, showy crotalaria, and pigweed, and the pot on the right has inoculated plants. 


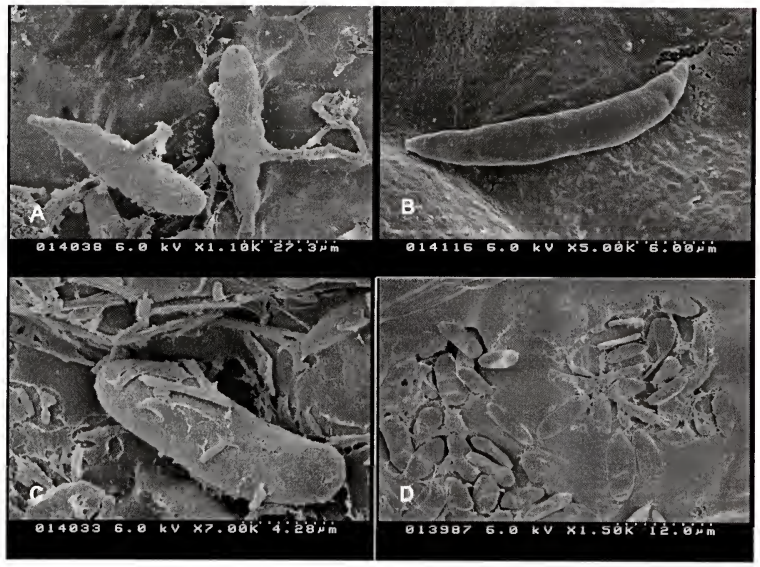

Figure 2-4. Scanning electron micrographs of spores of the fungal pathogens Alternaria cassiae (A), Colletotrichum dematium $\mathrm{f}$. $\mathrm{sp}$. crotalariae (B), Phomopsis amaranthicola (C), and Fusarium udum f. sp. crotalariae (D) on leaves of their respective hosts. 

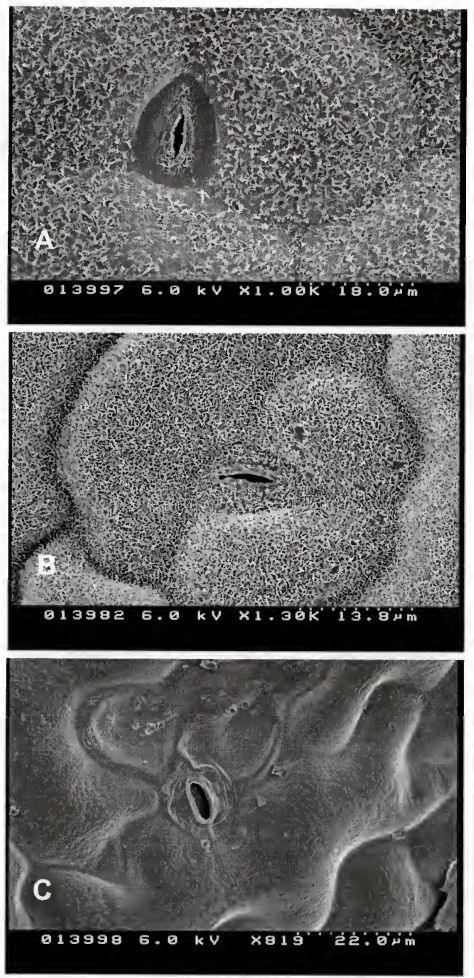

Figure 2-5. Scanning electron micrographs of leaf surfaces of sicklepod (A), showy crotalaria (B), and pigweed (C). 

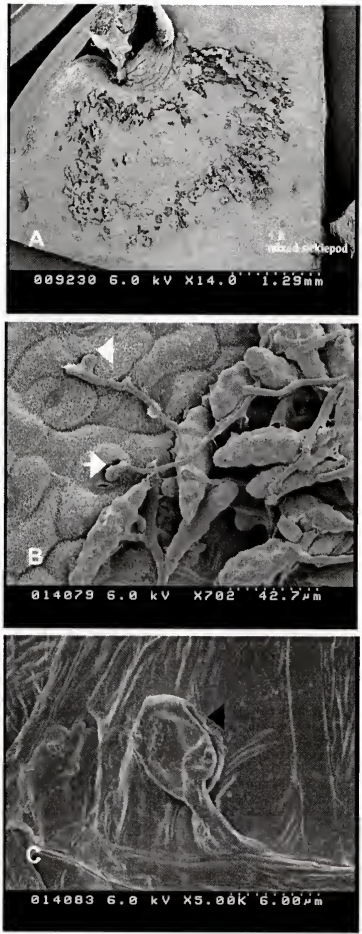

Figure 2-6. Scanning electron micrographs of host-specific responses of Alternaria cassiae in a pathogen mixture. Tissue maceration on sicklepod (host) leaf caused by the germinating spores (A), appressorium formation on showy crotalaria (alternative host) leaf (B), and lysis of appressorium on pigweed (nonhost) leaf(C). White arrows indicate healthy appressoria and black arrow indicates lysed appressorium. 

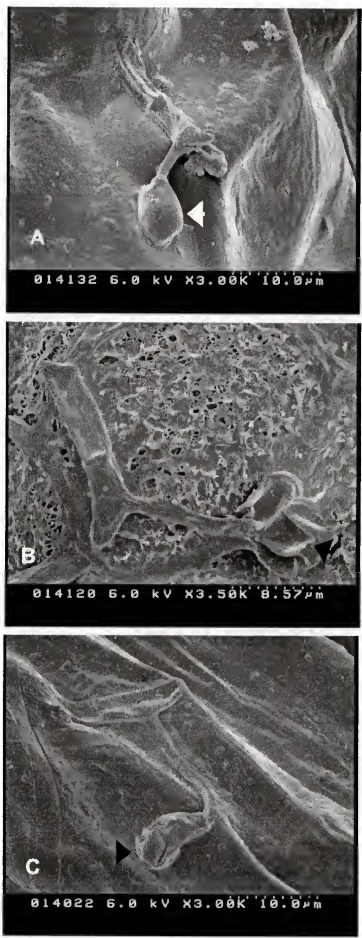

Figure 2-7. Scanning electron micrographs of host-specific responses of Colletotrichum dematium f.sp. crotalariae in a pathogen mixture. Appressorium formation on showy crotalaria (host) leaf (A), lysis of appressorium on sicklepod (nonhost) leaf (B), and lysis of appressorium on pigweed (nonhost) leaf $(\mathrm{C})$. White arrow indicates healthy appressorium and black arrows indicate lysed appressoria. 

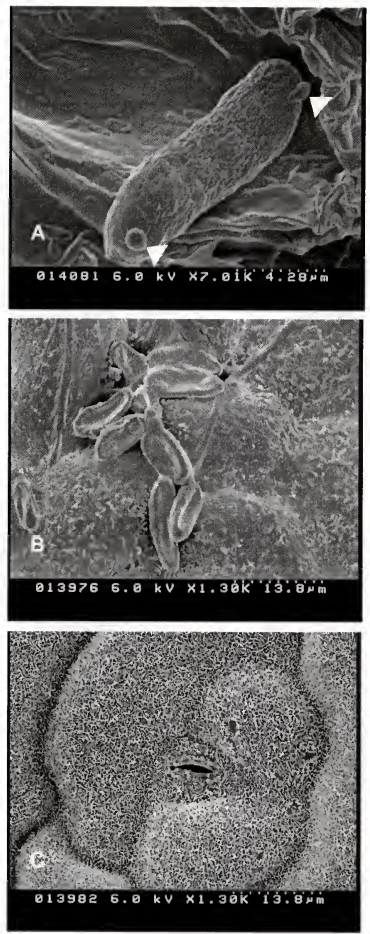

Figure 2-8. Scanning electron micrographs of host-specific responses of Phomopsis amaranthicola in a pathogen mixture. Spore germination on pigweed (host) leaf (A), absence of spore germination and shrivelling of spores on showy crotalaria (nonhost) leaf (B), lack of spore adhesion on sicklepod (nonhost) leaf(C). White arrows indicate initiation of spore germination. 

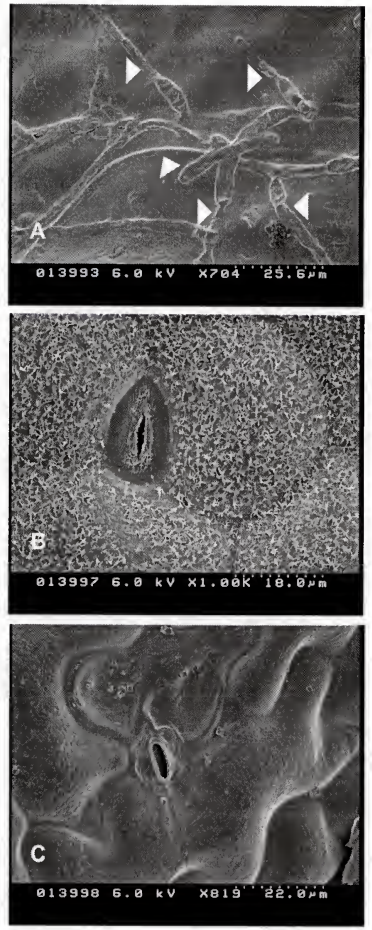

Figure 2-9. Scanning electron micrographs of host-specific responses of Fusarium udum $\mathrm{f}$. sp. crotalariae in a pathogen mixture. Spore germination on showy crotalaria (host) leaf (A), lack of spore adhesion on sicklepod (nonhost) leaf(B), and pigweed (nonhost) leaf (C). White arrows indicate spore germination and germtube formation. 
or poorly formed appressoria were observed on sicklepod and pigweed, the nonhosts (Figure 2-7 A,B,C). Phomopsis amaranthicola germinated and grew only on pigweed, while it did not grow on sicklepod or showy crotalaria (Figure 2-8 A,B,C). Fusarium udum f.sp. crotalariae, although a root-pathogen, germinated and grew on showy crotalaria leaves, but not on leaves of its nonhosts (Figure 2-9 A,B,C).

\section{Discussion}

\section{Evaluation of "Multiple-Pathogen Strategy" for Bioherbicidal Control of Several Weeds}

Currently available bioherbicides such as DeVine and Collego can each control only a single weed species. Simultaneous control of several weeds by bioherbicides will be limited by the host-specificity of plant pathogens and their narrow host-range. This is viewed as a problem for commercialization of bioherbicides which must compete in the marketplace with chemical herbicides that typically are usable against several weeds. However, this problem may be overcome by using a mixture of host-specific pathogens each of which can control a specific weed. A "Multiple-Pathogen Strategy" to control several weeds with a mixture of three or more pathogens, each of which is effective against some but not all weed hosts, has been tested here. This strategy, if feasible, will increase the spectrum of weeds controlled without loss of efficacy and host specificity.

In nature, plants are often attacked simultaneously by several pathogens, each causing discrete disease symptoms or together causing a complex of disease symptom (i.e., disease syndrome). Morin et al. (1993 a,b) observed that Colletotrichum orbiculare (Berk. \& Mont.) von Arx infected and induced necrotic lesions on or in the proximity of leaf or stem lesions of Puccinia xanthii Schw., a microcyclic rust pathogen of Xanthium spp. Following 
infection, C. orbiculare necrotized cells around the rust lesions, destroying living plant cells essential for the growth of the rust pathogen. Then, it spread beyond the rust lesions. Invasion of rust lesions by facultative saprophytic fungi has also been reported on the weeds, Senecio vulgaris L. (groundsel) (Hallet et al., 1990; 1992), Senecio jacobaea L. (ragwort) (Hallet, 1991), and Tussilago farfara L. (coltsfoot) (DeNooij \& Paul, 1992). In all such instances, the facultative parasites infected and killed the host tissue after colonizing the rust lesions. Also, occurrence of genotypic variations within a single weed species, as in the case ofyellow nutsedge, Cyperus esculentus L., affects its susceptibility to $P$ uccinia canaliculata (Schw.) Lagerh. (Okoli, et al., 1997). In such situations, it is desirable to use mixtures of biocontrol agents which can attack the different biotypes of the weed.

Increased bioherbicidal activity can occur due to synergism among pathogens, since they can act complementarily and compensate for any loss of efficacy of individual agents. Efficacy of Fusarium lateritium Nees ex Fr. to control spurred anoda (Anoda cristata (L.) Schlecht.) was enhanced when the plants were infected with another fungal pathogen (Alternaria macrospora Zimm.) prior to inoculation with $F$. lateritium Nees ex Fr. (Crawley \& Walker, 1983). Morin et al. (1993a) found Colletotrichum orbiculare, a pathogen of Xanthium spinosum L. to infect plants of $X$. occidentale Bertol. (nonhost), when the plants were predisposed to infection by a rust pathogen, Puccinia xanthii. Synergistic or antagonistic effects were not observed, when Exserohilum turcicum (Pass.) K.J. Leonard \& Suggs was applied in combination with either Gloeocercospora sorghi Bain \& Edgerton or Colletotrichum graminicola (Ces.) G.W. Wils. to control seedling johnsongrass (Chiang et al., 1989a). Even in the absence of synergism, fungal pathogens that are not antagonistic to one another can be used simultaneously to control a broad-spectrum of weeds. Also, the 
availability of several pathogens will be of value as it allows choice of a pathogen, should resistance develop to any one of the three pathogens.

In this study, $A$. cassiae completely killed sicklepod and showy crotalaria, and Colletotrichum dematium f.sp. crotalariae controlled showy crotalaria within a week after inoculation. Phomopsis amaranthicola completely killed pigweed 6 weeks after inoculation. The mixture of all pathogens completely killed sicklepod, showy crotalaria, and pigweed. It is thus feasible to use several pathogens simultaneously to control several weeds without loss of efficacy and host-specificity of each pathogen.

\section{Electron Microscopy of Host-Specific Responses of Pathogens in Mixture}

Fungi have evolved diverse strategies to invade plant tissue, to optimize growth in the plant, and to propagate (Knogge, 1996). Plant pathogenic fungi have developed mechanisms to traverse the plant's outer structural barriers, the cuticle, and the epidermal cell wall. To gain entry into the plant tissue, fungi generally secrete a mixture of hydrolytic enzymes, including cutinases, cellulases, pectinases, and proteases. Because these enzymes are also required for the saprophytic stages of the fungal life cycle, they are unlikely to be essential for pathogenesis, and each individual hydrolytic enzyme may not be absolutely necessary for penetration. However, this does not preclude the adaptation of biosynthetic regulation of the enzymes to the specific needs of a pathogen.

Enzymatic degradation of cutin, the structural polymer of the plant cuticle has been postulated as crucial for fungal pathogenicity, and cutinase is presumed to be involved in the penetration process (Kolattukudy, 1985; Nicholson \& Epstein, 1991). Alternatively, or in combination with hydrolytic enzymes, some fungi have developed a more complex and 
sophisticated mechanism to penetrate the cuticle of host plants. They form specialized penetration organs, called appressoria, at the tips of their germtubes. These organs are firmly attached to the plant surface by extracellular adhesives. As the appressorium develops, the porosity of the appressorial wall is markedly reduced by incorporation of melanin, allowing build up of turgor pressure inside the appressorium (Howard et al., 1991). This pressure is focused effectively on a small area at the base of the appressorium (penetration pore) that is kept free of wall material and melanin. From this penetration pore, an infection peg develops and pierces through the cuticle and cell wall, possibly assisted by hydrolytic enzymes (Mendgen \& Deising, 1993). Thus, penetration of cuticular barriers of plant hosts is likely to be controlled by a combination of different factors. In addition to fungal compounds, these factors may include plant surface structures as well as plant-derived activators or inhibitors of fungal germination and germtube formation (Knogge, 1996).

Interactions of fungal pathogens with their hosts involve perception of host signals, both physical and chemical, soon after the pathogen comes in contact with the host. The signal transduction leads to mutual expression of certain mechanisms that result in host resistance or susceptibility to the fungal pathogen. Alternaria cassiae germinated on all three weed hosts. On sicklepod, the major host, the spores collapsed upon germination and extensive tissue maceration was observed underneath and around the spores. Appressorium formation was absent. The parent spore often appeared empty, and sometimes collapsed, as in species of Colletotrichum, Phyllacora, and Phytophthora (Emmett \& Parbery, 1975). Van Dyke and Trigiano (1987) observed that conidia of Alternaria cassiae germinated within 2-3 $\mathrm{h}$ after contact with its host, sicklepod, and developed an average of six germ tubes per conidium within $24 \mathrm{~h}$. Germ tubes passed near stomata, but without appressorium formation. 
Hyphal penetrations were rarely observed prior to necrosis of mesophyll cells. Death of mesophyll cells in advance of fungal penetration suggests the action of one or more secreted enzymes or toxins. On showy crotalaria, the alternative host, spores of $A$. cassiae were not completely collapsed upon germination. Multiple germtubes formed from each conidium which differentiated into healthy appressoria. On pigweed, the nonhost, the appressoria lysed. It is unlikely that the pattern of penetration is the same in each host-parasite relationship. Initiation, formation, and penetration of host tissue by the appressorium are integral parts of the infection process of many parasitic fungi. In some fungal species, formation of appressoria may be obligatory for infection, while in others it may be optional or unnecessary (Emmett \& Parbery, 1975).

Spores of Colletotrichum dematium f.sp. crotalariae collapsed upon germination, followed by the formation of large, healthy appressoria over the anticlinal walls of the epidermal cell junctions on showy crotalaria. The location of appressoria over or near the anticlinal walls of epidermal cell junctions is documented in 22 species and 14 genera of fungi (Wynn \& Staples, 1981). In most of the fungi, appressoria are formed in response to a surface-contact stimulus as has been demonstrated most convincingly with species of Colletotrichum, in which appressoria are large and readily induced. On sicklepod and pigweed, the nonhosts, spores of $C$. dematium f.sp. crotalariae followed the same germination pattern as on showy crotalaria, the host, but the appressoria lysed before the tissue was penetrated. Thus, surface-contact seems to be a major stimulus for tropisms that control preinfection activity. The showy crotalaria seedlings inoculated with $C$. dematium f.sp. crotalariae alone did not show any visible disease symptoms up to 5 days after inoculation, when they suddenly collapsed. Many pathogens capable of producing highly 
active cell-wall degrading enzymes in vitro, e.g., Monilinia fructigen $a$ Honey in Whetzel and Phytophthora infestans (Mont.) de Bary often cause negligible wall degradation during invasion (Cooper, 1981). Colletotrichum lindemuthianum (Sacc. \& Magnus) Lams.-Scrib., a bean pathogen, initially penetrates cell walls mechanically, and does not cause any apparent damage to protoplasts during the first four days, and then it suddenly causes extensive wall breakdown and necrosis (Mercer et al., 1975).

The waxiness of the leaf surfaces of the three weed hosts differed greatly (Figure 2-5 a,b,c). Pigweed leaf surface appeared under SEM to be the least waxy. The cuticular wax was more densely packed in showy crotalaria than in sicklepod. Cuticles of some plants contain unique substances that stimulate germination of fungal spores. Kolattukudy et al. (1995) found that plant surface wax or factors in plant surface wax can serve as a signal to induce germination and appressorium formation in Colletotrichum gloeosporioides, an avocado pathogen. The induction was selective to the surface wax of the host alone, avocado, and not to other plant waxes. Also, the addition of other plant waxes to avocado wax inhibited the ability of avocado wax to induce appressorium formation. Thus, plant surface waxes appear to contain inducers and inhibitors of germination and appressorium formation by different fungi. Resistance in a nonhost to a pathogen appears to include leafsurface characteristics as a major component. Such is the case of resistance of Xanthium occidentale (nonhost) to Colletotrichum orbiculare, a pathogen of $X$. spinosum (host). Appressorium formation was much reduced on nonhost plants (Auld et al., 1994).

Spores of $P$. amaranthicola germinated and grew only on pigweed and those of $F$. udum f.sp. crotalariae germinated and grew only on showy crotalaria. Spores of $P$. amaranthicola and F. udum f.sp. crotalariae were absent on their nonhosts 24 - to 48 -h after 
inoculation, possibly due to their inability to adhere to the nonhost surfaces. Adsorption or binding of a plant-associated inducing agent (i.e., lectin) to the spore is reported to initiate germination in Fusarium solani (Mart.) Sacc. f.sp. phaseoli (Burkholder) W.C. Snyder \& H.N. Hans., a pathogen of mung bean (Vigna radiata (L.) R. Wilczek (Schuerger et al., 1993). Spore-binding lectins (agglutinins) have been described in hypocotyl cell walls of leguminous plants (Haasz et al., 1981). Thus, the attachment of spores of $P$. amaranthicola and $F$. udum f.sp. crotalariae may be induced by the presence of receptor sites on host plants. Plant waxes that are hydrophilic allow a greater exudation of material from within the leaf to its surface, than do waxes containing hydrophobic compounds. Availability of exudations at plant surfaces and the character of plant waxes can indirectly influence host susceptibility (Emmett \& Parbery, 1975).

Appressorium formation in some groups of fungi may require fairly well-defined environmental conditions, including contact with an appropriate surface. Specific interactions of the fungal genotype with the environment determines the metabolic climate within the fungus and this may determine whether appressoria will form. Modifications of contact-induction by chemicals present on the surface during spore germination have been observed with species of Colletotrichum and Gloeosporium (Emmett \& Parbery, 1975). Added nutrients suppressed formation of appressoria and elongation of germtubes. Thus, host plant exudates can play a significant role in the induction of appressoria. The stepwise formation of infection structures (appressorium, penetration peg, vesicle, and infection hyphae) is probably triggered by a single stimulus such as host plant-fractions (Wynn \& Staples, 1991). Although formation of infection structures is a single tropic response, it can be interrupted after appressorium formation on resistant or immune plants (e.g., 
appressorium lysis, aberrant appressoria). Features of the plant surface that a pathogen cannot recognize properly can lead to interference with normal tropism and disease development (Wynn \& Staples, 1991).

In this study, the growth patterns of the pathogens, $A$. cassiae, $C$. dematium $\mathrm{f}$. sp. crotalariae, P. amaranthicola, and $F$. udum f. sp. crotalariae were conditioned by specific interactions with the host leaf surfaces, whether the pathogens were applied alone or in a mixture. Thus, the specificity in host-recognition and host-parasite response was not compromised when the pathogens were mixed and applied to different weed hosts. 


\section{CHAPTER III \\ BIOHERBICIDAL CONTROL OF WEEDY GRASSES WITH A PATHOGEN MIXTURE}

\section{Introduction}

Weeds are managed in crops mainly by cultural, mechanical, and chemical control methods (Dao, 1987; Standifer et al., 1984; Teasdale et al., 1991). Herbicides used in intensively managed crop-production systems usually provide excellent weed control, but increased costs of herbicides and application have reduced net profit (Lybecker et al., 1984; Nastasi et al., 1986). Excessive use of agrochemicals in weed control has also led to associated environmental problems such as phytotoxicity to crops, persistence in soil, contamination of surface water and eventually groundwater, and development of resistance to herbicides in weeds (Schroeder \& Banks, 1986; Murphy et al., 1986). Consequently, there is a need for a more environmentally friendly alternative to chemical control of weeds. This need provides an opportunity to develop a biological control strategy of weeds, such as the use of plant pathogens as bioherbicides.

\section{Grasses as Weeds}

Among the most problematic weeds are some annual and perennial grasses, which are also among the worst weeds in the world in many crops in several countries (Holm et al,, 1977). The weeds are: bahiagrass, Paspalum notatum Fluegge; bermudagrass, Cynodon dactylon (L.) Pers.; large crabgrass, Digitaria sanguinalis (L.) Scop.; crowfootgrass, 
Dactyloctenium aegyptium (L.) Willd.; goosegrass, Eleusine indica (L.) Gaertn.; guineagrass, Panicum maximum Jacq.; johnsongrass, Sorghum halepense (L.) Pers.; napiergrass, Pennisetum purpureum Schumach.; natalgrass, Rhynchelytrum repens (Willd.) C.E.Hubb.; southern sandbur, Cenchrus echinatus L.; Texas panicum, Panicum texanum L.; torpedograss, Panicum repens L.; vaseygrass, Paspalum urvillei Steud.; and yellow foxtail, Setaria glauca (L.) Beauv. These grasses cause yield losses in many crops such as corn (Bendixen, 1986); cotton (Bridges \& Chandler, 1987; Keele \& Thullen, 1991); peach (Weller et al., 1985); and soybeans (Williams \& Hayes, 1984). In a crop like citrus, weedy grasses compete for moisture, nutrients, and light and can inhibit the growth of young trees and delay fruit production. These weeds are difficult to control, either because of their tolerance to available chemical herbicides or due to their growth habits that enable them to escape from other control practices (Akins, 1994).

The discovery and development of host-specific fungal plant pathogens as bioherbicides would provide a nonchemical option to manage weedy grasses. However, currently there is no bioherbicide available to control weedy grasses. The following fungal plant pathogens have been reported as potential bioherbicides: Sphacelotheca holci Jack. [= S. cruenta (Kuhn.) Potter] for johnsongrass (Massion \& Lindow, 1986); Bipolaris setariae (Saw.) and Pyricularia grisea (Cke.) Sacc. for goosegrass (Figliola et al., 1988); Exserohilum turcicum (Pass.) Leonard \& Sugg., Colletotrichum graminicola (Ces.) G. W. Wils., Gleoocercospora sorghi Bain \& Edgerton, and Bipolaris halepense Chiang, Leonard and Van Dyke for johnsongrass (Chiang et al., 1989a); Bipolaris sorghicola (Lefebvre \& Sherwin) Alcorn, and another unidentified species of Bipolaris for johnsongrass (Winder \& Van Dyke, 1990); and Exserohilum monoceras (Drechs.) K.J. Leonard \& E.G. Suggs for 
Echinocloa spp. (Zhang \& Watson, 1997a). The fungal pathogens of johnsongrass were not developed further as bioherbicides due to lack of consistent efficacy and/or difficulty in mass production of the inoculum.

The objectives of this study were to i) identify and characterize three indigenous fungal plant pathogens isolated from diseased grasses and ii) evaluate the bioherbicidal efficacy of each pathogen and a mixture of all three pathogens.

\section{Materials and Methods}

\section{Isolation, Identification, and Characterization of Fungal Isolates}

Diseased leaves of large crabgrass, crowfootgrass, and johnsongrass were collected from various locations in Florida. The leaf pieces $\left(4 \mathrm{~mm}^{2}\right)$ with disease lesions were cut, surface-sterilized with $0.5 \%$ sodium hypochlorite solution, rinsed twice with sterile water, and plated on potato dextrose agar (PDA; Difco, Detroit, MI) in petri plates. After 2-3 days of incubation $\left(25^{\circ} \mathrm{C}, 12 \mathrm{~h} / 12 \mathrm{~h}\right.$ light/dark, $\left.35 \pm 5 \mu \mathrm{E} / \mathrm{m}^{2} / \mathrm{s}\right)$, fungi that grew out from lesions on the leaf pieces were transferred to fresh PDA, and incubated as before for 1 week. After the fungi were identified to the genus level based on their conidial morphology and growth characteristics, pure cultures of the fungi were prepared from hyphal tips or single spores, and maintained on PDA slants and in soil in test tubes as stock cultures.

The identification and characterization of the fungi to the species level were limited to isolates that were confirmed to be pathogenic to their specific hosts. The morphology of conidia and conidial measurements were recorded for each isolate. Conidial measurements were obtained with a calibrated ocular micrometer for 50-100 conidia per isolate. Conidial germination was studied in a drop of conidial suspension spread over $2 \%$ water agar plates. 
The plates were incubated as before. After $24 \mathrm{~h}$ of incubation, the nature of germination of each isolate was observed under a light microscope. Conidial morphology, dimensions, and germination characteristics were used to compare with known species of fungi described in the literature.

\section{Production of Grass Seedlings}

Pathogenicity of the isolated fungi was tested on their respective weed hosts. Seedlings of weed species to be tested were raised from seeds (Valley Seed Services, Fresno, CA). When the seedlings emerged, they were transplanted to $10 \mathrm{~cm}$-diam $\times 10.63-\mathrm{cm}$-tall plastic pots containing a commercial potting medium (Metromix 300; Scott's Sierra Horticultural Products Co., Marysville, Ohio). Five plants of a single weed species were grown in each pot. The seedlings were allowed to become established, and were maintained in a greenhouse. The seedlings were watered to soil saturation.

\section{Pathogenicity Testing}

The seedlings at 2- to 4-leaf stage of each species of grass were inoculated with their respective pathogens. Conidial suspensions of $10^{5} \mathrm{spores} / \mathrm{ml}$ of each pathogen were amended with $0.5 \%$ Metamucil $^{\star}$, a humectant, the humectant was allowed to gel (about 30 $\mathrm{min}$ ), and the suspension was sprayed on the grass seedlings until runoff with a hand-held plastic sprayer. Noninoculated controls were sprayed with water amended with $0.5 \%$ Metamucil only. All seedlings were held in a dew chamber (100\% relative humidity (RH), $25 \pm 5^{\circ} \mathrm{C}$ day/night) in the dark for $12 \mathrm{~h}$. The plants were then removed and moved to a greenhouse $\left(35 / 25 \pm 5^{\circ} \mathrm{C}\right.$ day/night, $\left.85 \pm 5 \% \mathrm{RH}\right)$ and examined daily until disease symptoms 
appeared. Disease incidence and disease severity were recorded 2 weeks after inoculation. Diseased leaves were collected and the fungi were reisolated from symptomatic lesions to confirm Koch's postulates.

\section{Inoculum Production}

A small mycelial plug from a stock culture was aseptically transferred to fresh modified V8 agar (200 $\mathrm{ml}$ V8 juice, $800 \mathrm{ml}$ water, $14 \mathrm{~g}$ agar; Dhingra \& Sinclair, 1995). The plates were incubated for $1-2$ days $\left(25^{\circ} \mathrm{C}, 12 \mathrm{~h} / 12 \mathrm{~h}\right.$ light/dark, $\left.35 \pm 5 \mu \mathrm{E} / \mathrm{m}^{2} / \mathrm{s}\right)$ until adequate colony growth was observed. Mycelial plugs from the margins of a growing young colony were transferred to fresh plates of V8 agar ( 5 plugs per plate). The plates were incubated as before for 2 weeks. To harvest the conidia, the agar plates were flooded with $10 \mathrm{ml}$ distilled water and the spores were scraped off the plates with a rubber spatula. The resulting conidial suspensions were passed through a single layer of cheesecloth. The concentration of spores was determined with a haemocytometer, and the spore suspension was adjusted to the desired concentration by dilution in water.

\section{Bioherbicidal Efficacy of a Pathogen Mixture}

In trials conducted in a greenhouse, the pathogens were tested on the following seven grasses: large crabgrass, crowfootgrass, guineagrass, johnsongrass, southern sandbur, Texas panicum, and yellow foxtail. Four-wk-old seedlings were inoculated with spore suspensions $\left[2 \times 10^{5}\right.$ spores per $\left.\mathrm{ml}\right]$ of each pathogen. A mixture of pathogens, each at equal volume and a total of $2 \times 10^{5}$ spores per $\mathrm{ml}$ was also tested. Inoculum suspensions as well as the control (water only) were amended with $0.5 \%$ Metamucil. The seedlings were sprayed 
until runoff, provided $12 \mathrm{~h}$ of dew in a dew chamber in the dark at $28^{\circ} \mathrm{C}$, and then moved to a greenhouse.

\section{Disease Assessment}

Disease was assessed as disease incidence and disease severity. Disease incidence was based on the number of plants affected among the total plants inoculated, expressed as the percentage of diseased plants (Horsfall \& Cowling, 1978; Kranz, 1988). Disease severity rating was based on the Horsfall-Barratt scale (Horsfall \& Barratt, 1945). There are 12 classes in this scale which correspond to different levels of disease severity. The classes were: $0=0 ; 1=0-3 \% ; 2=3-6 \% ; 3=6-12 \% ; 4=12-25 \% ; 5=25-50 \% ; 6=50-75 \% ; 7=75$ $88 \% ; 8=88-94 \% ; 9=94-97 \% ; 10=97-100 \%$ and $11=100 \%$. The mean class value was used to determine the final disease severity value.

\section{Data Analysis}

The experiments were done twice. A randomized complete block design with three replicates was used for all experiments. All percentage data were transformed by arcsine before analysis (Gomez \& Gomez, 1984). Analysis of variance (ANOVA) using the General Linear Model (GLM) was used (SAS Institute, Cary, NC). Disease severities from the two trials were pooled since the mean square errors were of the same magnitude. 


\section{Results}

\section{Isolation, Pathogenicity, and Characterization of Fungi}

Four different fungi were isolated from specimens of diseased grass leaves collected from various locations within Florida (Table 3-1). The pathogenicity of these isolates was tested on the respective hosts from which they were isolated. Three of the fungi were highly pathogenic to their hosts when spray-inoculated with a suspension. The disease symptoms appeared within $24 \mathrm{~h}$ after inoculation as eye-spot lesions associated with extensive necrosis on leaves (Figure 3-1). The lesions did not coalesce, but leaves and even entire plants turned completely necrotic and died, if the leaf surfaces were completely covered with the spore suspension. There was no significant secondary infection cycle as seen from lack of appearance of new lesions on noninoculated tissue. The fungi were reisolated from the respective infected host plants and Koch's postulates were fulfilled.

The shape and dimensions, hilum morphology, and germination pattern of spores of the three highly pathogenic fungi were examined (Table 3-2, Figure 3-2). Based on these characteristics and through comparison with taxonomic descriptions, these fungi were identified as Drechslera gigantea (Heald \& Wolf) Ito, Exserohilum longirostratum (Subram.) Sivan., and E. rostratum (Drechsler) Leonard \& Suggs. (Alcorn, 1988; Sivanesan, 1987). Conidia of Drechslera gigantea were straight to somewhat curved, cylindrical, 9distospetate, and measured 92.4-123.2x8.8-11.0 $\mu \mathrm{m}$. Conidia of Exserohilum longirostratum were straight to slightly curved, broadest around the basal part, narrowed gradually towards the apex into a long beak, and measured 60.0-475.0x12.0-26.0 $\mu \mathrm{m}$. The germination was usually bipolar with the basal hypha growing semiaxially to the orientation of the spore. Conidia of Exserohilum rostratum were straight, ellipsoidal to narrowly obclavate or rostrate, 
Table 3-1. Fungi isolated from diseased weedy grasses, their origin, and their pathogenicity.

\begin{tabular}{lllc}
\hline Fungal Isolate & Host Plant & Origin & Pathogenicity \\
\hline Drechslera gigantea & Large crabgrass & Leesburg, FL & +++ \\
Exserohilum longirostratum & Crowfootgrass & Belle Glade, FL & +++ \\
Exserohilum rostratum & Johnsongrass & Gainesville, FL & +++ \\
Helminthosporium sp. & Southern sandbur & Leesburg, FL & - \\
\hline
\end{tabular}

$t=$ Pathogenic, $100 \%$ disease incidence, less than $25 \%$ disease severity.

$++=$ Pathogenic, $100 \%$ disease incidence, $50-75 \%$ disease severity.

$+++=$ Pathogenic, $100 \%$ disease incidence, $75-100 \%$ disease severity.

- = Plants did not develop disease symptoms (nonpathogenic). 


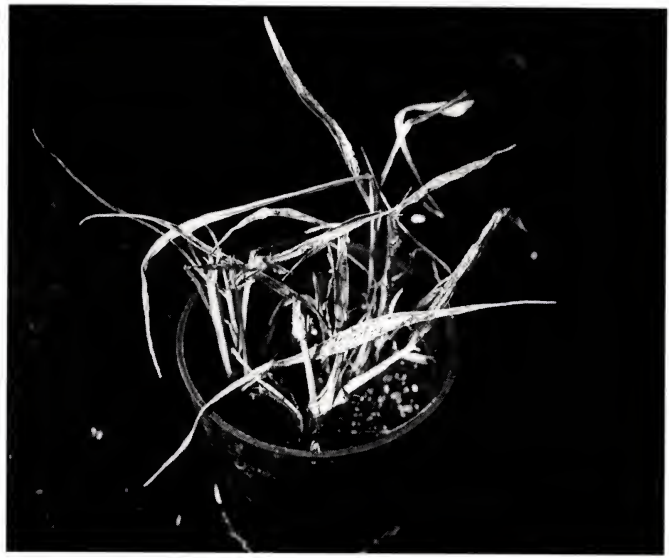

Figure 3-1. Disease symptoms on guineagrass inoculated with Drechslera gigantea. Symptoms indistinguishable from these (above) were seen when inoculated with Exserohilum longirostratum, Exserohilum rostratum, or a mixture of the three pathogens. 
Table 3-2. A comparison of conidial dimensions of the isolated fungi ${ }^{b}$ with those described in the literature ${ }^{\mathrm{a}}$.

(Tentative name)

$\begin{array}{lll}\begin{array}{l}\text { Length }(\mu \mathrm{m}) \\ \text { range }\end{array} & \begin{array}{l}\text { Width }(\mu \mathrm{m}) \\ \text { range }\end{array} & \begin{array}{l}\text { No. of } \\ \text { cells/conidium } \\ \text { (Mean) }\end{array}\end{array}$

Drechslera gigantea

$200-390 \quad 15-30 \quad 3-6$

(Heald \& Wolf) Ito ${ }^{a}$

Exserohilum longirostratum

(Subram.) Sivan. ${ }^{a}$

$60-475 \quad 12-26 \quad 7-10$

Exserohilum rostratum

(Drechsler) Leonard \& Suggs. ${ }^{a}$

$15-200$

$7-29$

6-18

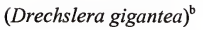

$92-123$

$9-11$

9

(E. longirostratum $)^{\mathrm{b}}$

$110-180$

$9-13$

9-10

(E. rostratum $)^{\mathrm{b}}$

$57-112$

9-13

6-8

a Sivanesan, 1987. 
A.

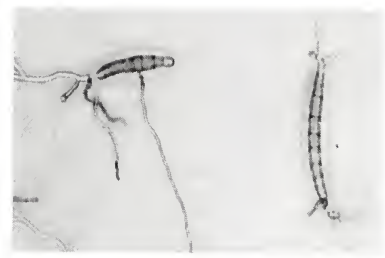

B.

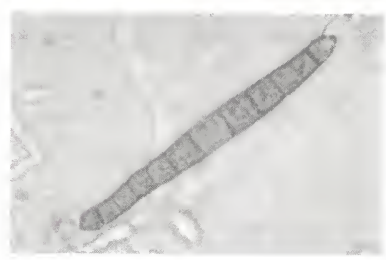

C.

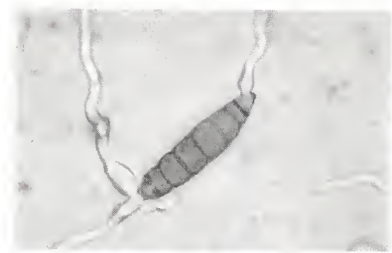

Figure 3-2. Germinating spores of Drechslera gigantea (A), Exserohilum longirostratum (B), and E. rostratum (C). 
hilum protruding from the end of basal cell, 6-distoseptate, and measured 15.0-200.0x7.0$29.0 \mu \mathrm{m}$. The conidial morphology, dimensions, and germination patterns were comparable to those described for Drechslera gigantea (Heald \& Wolf) Ito, Exserohilum longirostratum (Subram.) Sivan., and E. rostratum (Drechsler) Leonard \& Suggs. (Alcorn, 1988; Sivanesan, 1987; Dr.J. Kimbrough, University ofFlorida, Gainesville, personal communication). Thus, the three fungi were identified to the species level.

Bioherbicidal Efficacy of Drechslera gigantea, Exserohilum longirostratum, and E. rostratum.

All weedy grasses tested were highly susceptible to the individual pathogens as well as a mixture of all three pathogens. The weeds tested had $100 \%$ disease incidence (Table 33) and were highly susceptible with disease severity ranging from $82.5-100 \%$ (Table 3-4, Figures 3-4 to 3-8). The pathogen mixture was either superior or comparable to the individual pathogens in its efficacy in controlling the grassy weeds tested $(p=0.01)$. Thus, these pathogens have potential to be used as bioherbicides to control large crabgrass, crowfootgrass, johnsongrass, guineagrass, yellow foxtail, Texas panicum, and southern sandbur.

\section{Discussion}

Of four fungi isolated from various grasses and tested for pathogenicity, three from large crabgrass, crowfootgrass, and johnsongrass were highly pathogenic to their respective host of origin. In repeated trials, the pathogenicity of the fungi to their respective hosts was confirmed by Koch's postulates. In efficacy trials, these pathogens caused high levels of 
Table 3-3. Effect of inoculation with Drechslera gigantea (Dg), E. longirostratum (E1), E. rostratum $(\mathrm{Er})$, and a mixture of all three pathogens on disease incidence (\%) at 2 weeks after inoculation.

Isolate

\begin{tabular}{lllllc}
\hline Weed & $\begin{array}{l}\text { Age of host } \\
\text { (weeks) } \\
\text { at inoculation }\end{array}$ & Dg & El & Er & $\begin{array}{c}\text { Mix } \\
(1: 1: 1 \mathrm{v} / \mathrm{v})\end{array}$ \\
\hline Large crabgrass & 4 & 100 & 100 & 100 & 100 \\
Crowfootgrass & 4 & 100 & 100 & 100 & 100 \\
Johnsongrass & 4 & 100 & 100 & 100 & 100 \\
Guineagrass & 4 & 100 & 100 & 100 & 100 \\
Southern sandbur & 4 & 100 & 100 & 100 & 100 \\
Texas panicum & 4 & 100 & 100 & 100 & 100 \\
Yellow foxtail & 4 & 100 & 100 & 100 & 100 \\
\hline
\end{tabular}


Table 3-4. Effect of inoculation with Drechslera gigantea (Dg), E. longirostratum (El), E. rostratum (Er), and a mixture of all three pathogens on disease severity (\%) 2 weeks after inoculation.

\begin{tabular}{|c|c|c|c|c|c|}
\hline \multirow[b]{2}{*}{ Weed } & & \multicolumn{4}{|c|}{ Isolate $^{a}$} \\
\hline & $\begin{array}{l}\text { Age of Host } \\
\text { (weeks) } \\
\text { at inoculation }\end{array}$ & Dg & $\mathrm{El}$ & $\mathrm{Er}$ & $\begin{array}{c}\text { Mix } \\
(1: 1: 1 \mathrm{v} / \mathrm{v})\end{array}$ \\
\hline Large crabgrass & 4 & $90 \mathrm{a}$ & $83 \mathrm{~b}$ & $83 \mathrm{~b}$ & $89 a$ \\
\hline Crowfootgrass & 4 & $95 \mathrm{a}$ & $95 \mathrm{a}$ & $95 \mathrm{a}$ & $95 \mathrm{a}$ \\
\hline Johnsongrass & 4 & $95 \mathrm{a}$ & $95 \mathrm{a}$ & $95 \mathrm{a}$ & $95 \mathrm{a}$ \\
\hline Guineagrass & 4 & $100 \mathrm{a}$ & $100 \mathrm{a}$ & $100 \mathrm{a}$ & $100 \mathrm{a}$ \\
\hline Southern sandbur & 4 & $100 \mathrm{a}$ & $100 \mathrm{a}$ & $100 \mathrm{a}$ & $100 \mathrm{a}$ \\
\hline Texas panicum & 4 & $100 \mathrm{a}$ & $100 \mathrm{a}$ & $100 \mathrm{a}$ & $100 \mathrm{a}$ \\
\hline Yellow foxtail & 4 & $100 \mathrm{a}$ & $100 \mathrm{a}$ & $100 \mathrm{a}$ & $100 \mathrm{a}$ \\
\hline
\end{tabular}




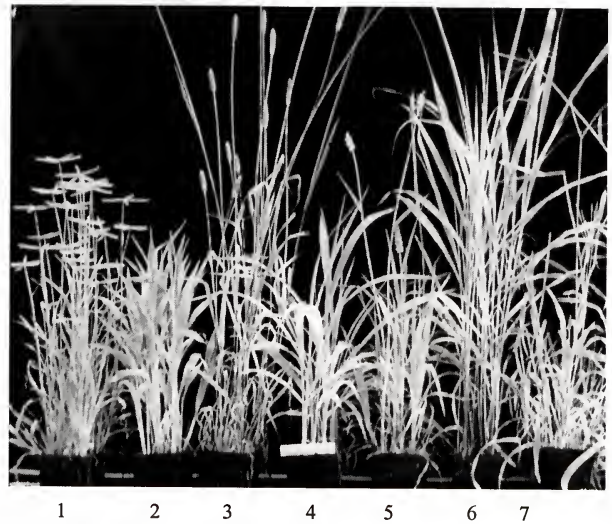

Figure 3-4. Noninoculated control plants of seven weedy grasses. (1) crowfootgrass,(2) Texas panicum, (3) yellow foxtail, (4) guineagrass, (5) southern sandbur, (6) johnsongrass, and (7) large crabgrass. 


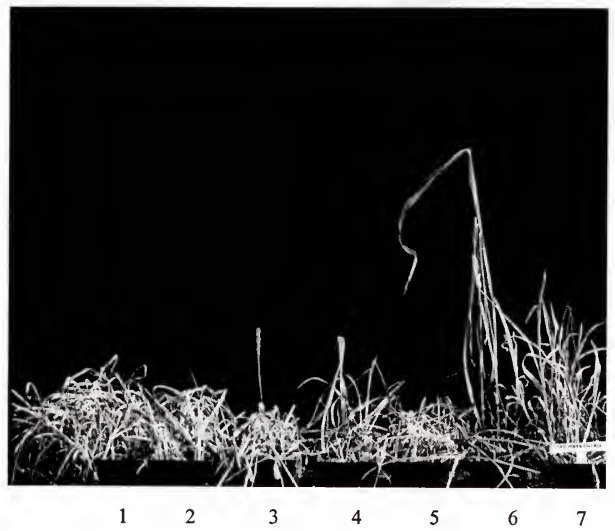

Figure 3-5. Effect of inoculation with Drechslera gigantea on seven weedy grasses at 2 weeks after inoculation. (1) crowfootgrass, (2) Texas panicum, (3) yellow foxtail, (4) guineagrass, (5) southern sandbur, (6) johnsongrass, and (7) large crabgrass. 


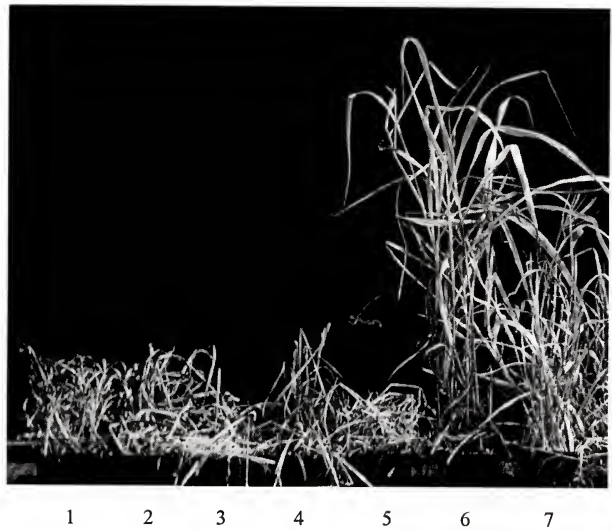

Figure 3-6. Effect of inoculation with Exserohilum longirostratum on seven weedy grasses at 2 weeks after inoculation. (1) crowfootgrass, (2) Texas panicum, (3) yellow foxtail, (4) guineagrass, (5) southern sandbur, (6) johnsongrass, and (7) large crabgrass. 


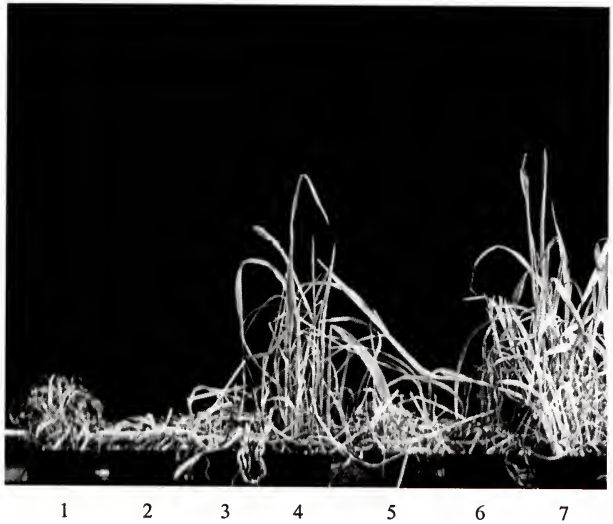

Figure 3-7. Effect of inoculation with Exserohilum rostratum on seven weedy grasses at 2 weeks after inoculation. (1) crowfootgrass, (2) Texas panicum, (3) yellow foxtail, (4) guineagrass, (5) southern sandbur, (6) johnsongrass, and (7) large crabgrass. 


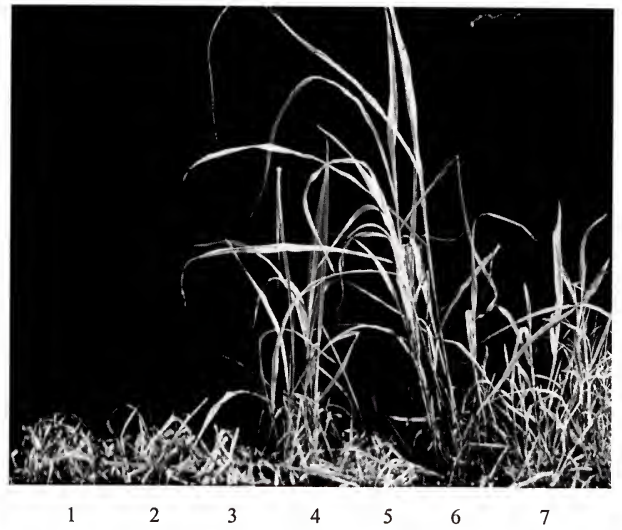

Figure 3-8. Effect of inoculation with a mixture of Drechslera gigantea, Exserohilum longirostratum, and $E$. rostratum $(1: 1: 1 \mathrm{v} / \mathrm{v})$ on seven weedy grasses at 2 weeks after inoculation. (1) crowfootgrass, (2) Texas panicum, (3) yellow foxtail, (4) guineagrass, (5) southern sandbur, (6) johnsongrass, and (7) large crabgrass. 
disease on seven weedy grasses: large crabgrass, crowfootgrass, johnsongrass, guineagrass, southern sandbur, Texas panicum, and yellow foxtail. The fungi were identified as: Drechslera gigantea, Exserohilum longirostratum, and E. rostratum. Thus, they were considered to be the causal agents of the respective disease symptoms observed.

All three pathogens induced eyespot lesions typical of infections by Drechslera and Exserohilum species and induced a severe "burnt" appearance on the foliage of highly susceptible hosts. The individual lesions did not expand and coalesce, but leaf tissue in the vicinity of heavy spore deposition was completely killed. Symptoms appeared within $24 \mathrm{~h}$ of inoculation when the inoculated plants were exposed to $100 \%$ relative humidity. The disease did not develop on noninoculated tissue on the same diseased plants, which was indicative of localized infection and lack of significant secondary disease cycles. There was no regrowth of severely diseased plants even 4 weeks after inoculation. The disease symptoms were quite characteristic of leaf spot diseases on graminicolous hosts caused by fungal species of Drechslera and Exserohilum (Sivanesan, 1987).

Phytotoxins may be involved in pathogenesis and rapid necrosis caused by $D$. gigantea, E. longirostratum, and E. rostratum on the weedy grasses tested. Toxins produced by some species of Helminthosporium group of fungi are important in plant pathogenesis (Walton \& Panaccione, 1993). They are: (1) HC-toxin, a cyclic tetrapeptide produced by Cochliobolus carbonum R.R. Nelson, causal agent of northern leaf blight of maize. The toxin produced by this fungus is selectively active against maize that is homozygous recessive at the Hm locus. The Hm gene encodes an enzyme, HC-toxin reductase that detoxifies the HC-toxin in the resistant (heterozygous at Hm locus) maize cultivars (Johal \& Briggs, 1992; Walton, 1996). (2) T-toxin, a linear polyketide produced by Cochliobolus 
heterostrophus (Drechs.) Drechs., causal agent of southern leaf blight of maize with Texas male-sterile cytoplasm. Susceptibility of maize to the toxin is caused by the presence of Turf 13, a gene unique to the mitochondrial chromosome of T-cytoplasm maize (Levings \& Siedow, 1992). (3) Victorin, a chlorinated cyclic pentapeptide produced by Bipolaris victoriae (F.Meehen \& Murphy) Shoem., causal agent of Victoria blight of oats. A single locus in oats $(\mathrm{vb})$ controls reaction to both the pathogen and toxin. Plants bearing the dominant allele are susceptible, and homozygous recessive alleles are resistant (Luke \& Wheeler, 1955; Pringle \& Scheffer, 1964). The ability of HC-toxin and T-toxin to cause plant disease on specific maize varieties have been firmly established (Panaccione et al., 1992; Yang et al., 1996).

The following is a list of some other phytotoxins and fungi that produce them: Ophiobolin, a sesterterpenoid by Bipolaris maydis (Nisik. \& Miyake) Shoem. (Sugawara et al., 1987); helminthosporoside, a sesquiterpenoid bis-digalactoside by Helminthosporium sacchari E.J.Butler (Beier et al., 1982); triticones, spirocyclic lactams by Drechslera triticirepentis (Died.) Shoemaker (Hallock et al., 1993); and monocerin, a lipophylic toxin by Exserohilum turcicum (Pass.) K.J.Leonard \& E.G.Suggs (Cuq et al., 1993). In addition to host-selective toxins, secondary metabolites that are known or believed to be important in plant/pathogen interactions include nonselective toxins (Ballio, 1991). Twelve eromophilanes (sesquiterpenes) have been isolated from culture broths of $D$. gigantea, and most of them have been found to be phytotoxic to several grasses (Sugawara et al., 1993).

Fungi that used to be placed in the genus "Helminthosporium" have been reclassified by Alcorn (1988) and are now placed under Drechslera, Bipolaris, and Exserohilum with Pyrenophora, Cochliobolus, and Setosphaeria as their respective teleomorphs. The new 
classification is based mainly on conidial morphology, germination characteristics, and hilum morphology. Drechslera was established by Ito (1930) to accommodate fungi previously assigned to the subgenus Cylindro-Helminthosporium. Members of the genus were characterized as having "cylindrical, not curved conidia, germinating from every cell and associated with Pyrenophora." Drechslera tritici-vulgaris (Nisik.) Ito (= D. triticirepentis [Died.] Shoem.) was designated as the lectotype. Shoemaker(1959) established the genus Bipolaris for species placed in the subgenus Eu-Helminthosporium. Conidia were described as fusoid, straight or curved, germinating by one germ tube from each end. Bipolaris maydis (Nisik. \& Miyake) Shoem. was selected as the type species. Some species of Bipolaris are associated with Cochliobolus as the teleomorph. Leonard and Suggs (1974) established the genus Exserohilum for Helminthosporium species in which the conidial hilum was strongly protuberant, thus providing the third segregate for the graminicolous species of fungi once considered to belong to the genus Helminthosporium. The type species described was E. turcicum (Pass.) Leonard \& Suggs. In addition, a new ascomycete genus, Setosphaeria, was proposed to accommodate teleomorphs of species of Exserohilum.

Based on the conidial and hilum morphology and germination characteristics (Figure 3-2), and conidial dimensions (Table 3-2) reported for previously described species, the fungal pathogens isolated from large crabgrass, crowfootgrass, and johnsongrass were identified as Drechslera gigantea (Heald \& Wolf) Ito, Exserohilum longirostratum (Subram.) Sivan., and Exserohilum rostratum (Drechsler) Leonard \& Suggs., respectively. These identifications were independently verified by Dr. J. Kimbrough (University of Florida, Gainesville, personal communication). 
Currently, there are no bioherbicides commercially available to control weedy grasses. A few fungal plant pathogens have been evaluated for their potential to control weedy grasses. In 1986, Massion and Lindow studied Sphacelotheca holci Jack., a smut pathogen that systemically infected johnsongrass seedlings and virtually eliminated seed-set. This lack of seed-set might eventually reduce the weed seed bank over time. Biotrophic fungi such as $S$. holci are difficult to mass produce and therefore difficult to develop as bioherbicides. Bipolaris setariae (Saw.) and Pyricularia grisea (Cke.) Sacc., two leafspotting pathogens of grasses have been found to be effective to control goosegrass under greenhouse conditions when provided a 72 -h dew period at $28^{\circ} \mathrm{C}$ (Figliola, et al., 1988). Exserohiulm turcicum, (Pass.) K.J. Leonard \& E.G. Suggs, Colletotrichum graminicola (Ces.) G.W. Wils., Gloeocercospora sorghi Bain \& Edgerton, and Bipolaris halepense Chiang, Leonard and Van Dyke have been studied for their potential to control johnsongrass (Chiang et al., 1989a). Exserohiulm turcicum caused the maximum level of disease on johnsongrass, when $2 \times 10^{5}$ spores $/ \mathrm{ml}$ was used and a 24 -h dew period was provided. Very young seedlings of johnsongrass ( 7 days after emergence) were more susceptible to these fungi than older plants $(14,21$, or 28 days after emergence). Chiang et al. (1989a) reported that repeated inoculations with $E$. turcicum resulted in more disease severity than a single inoculation on plants at $15 \mathrm{DAE}$. The disease was limited to leaves and sheaths exposed to the inoculum. Diseased seedlings resumed growth and developed new leaves. None of these fungi completely killed johnsongrass.

Winder and Van Dyke (1990) studied Bipolaris sorghicola and an unidentified species of Bipolaris sp. to control johnsongrass. Bipolaris sorghicola was capable of causing mortality in the greenhouse, but it was not feasible to mass produce the inoculum. Bipolaris 
sp. was less virulent and its efficacy was inconsistent, when tested in different field locations. In view of these results, the biocontrol potential of these two species was uncertain. In Australia, Drechslera avenacea (Eidam.) Scharif. and Pyrenophora semeniperda Brittlebank \& Adam have been identified as potential biocontrol agents, and are being evaluated for their efficacy to control wild oat (Avena fatua L.) and annual ryegrass (Lolium rigidum Gardin) (Hetherington et al., 1996). These pathogens are undergoing further investigations.

Zhang et al. (1996) isolated six pathogenic fungi from naturally infected Echinocloa spp. Among them, Exserohilum monoceras (Drechs.) K.J. Leonard \& Suggs killed seedlings of E. crus-galli (L.) P. Beauv., E. colonum (L.) Link, and E. glabrescens Munro ex Hook. F. when provided a 12-h dew period. Seedlings at the 1- and 2-leaf stages were more susceptible than those at the 3- and 4-leaf stages. The minimum dew period required to achieve $100 \%$ mortality was $16 \mathrm{~h}$ for E. colonum, $12 \mathrm{~h}$ for $E$. crus-galli, and $8 \mathrm{~h}$ for $E$. glabrescens (Zhang \& Watson, 1997a). With an increase in inoculum density, the weed control efficacy of this fungus could be enhanced on young as well as old Echinocloa seedlings (Zhang \& Watson, 1997b). Exserohilum monoceras does not control other weedy grasses considered in this study.

Temperature and dew period influence the efficacy of fungal bioherbicidal agents. The necessity for prolonged exposure to dew is a major limiting factor in the development of fungi as bioherbicides. Many of the fungi developed as bioherbicides require an optimum dew period of about $12 \mathrm{~h}$ and temperatures in the range of 20 to $30^{\circ} \mathrm{C}$. Alternaria cassiae Jurair and Khan required a dew period of at least 6 to $8 \mathrm{~h}$ for $90-100 \%$ kill of seedlings of sicklepod (Senna obtusifolia (L.) Irwin \& Barneby) under greenhouse and field conditions (Walker \& Boyette, 1986). Colletotrichum dematium (Pers. Ex Fr.) Grove f. sp. crotalariae 
gave 90 to $100 \%$ kill of 6- to 8-day-old crotalaria seedlings within 6 to 14 days, when given a dew period of $6 \mathrm{~h}$ under greenhouse conditions (Charudattan, 1988b).

Phomopsis amaranthicola sp. nov. induced a high level of mortality of Amaranthus spp., when plants were exposed after inoculation to a minimum of $8 \mathrm{~h}$ of dew. Exposure to dew durations of 12 and $24 \mathrm{~h}$ did not yield significantly higher levels of plant mortality. Dew temperatures of $25^{\circ} \mathrm{C}, 30^{\circ} \mathrm{C}$, and $35^{\circ} \mathrm{C}$ were found to be conducive for disease development and plant mortality. These optimal temperatures for disease development and plant mortality fall within the temperature range that occurs in Florida during the growing season of the weed (Rosskopf, 1997).

The optimal temperature and dew period required by Exserohilum monoceras to cause $100 \%$ mortality of Echinocola crus-galli, E. colonum, and E. glabrescens were 20$30^{\circ} \mathrm{C}$ and 8 - to $16-\mathrm{h}$. The minimium dew period duration required to achieve $100 \%$ mortality was $8 \mathrm{~h}$ for $E$. glabrescens, $12 \mathrm{~h}$ for $E$. crus-galli, and $16 \mathrm{~h}$ for $E$. colonum. Optimum temperatures of $24-28^{\circ} \mathrm{C}$ and dew period of at least $12 \mathrm{~h}$ was needed for Pyricularia grisea (Cke.) Sacc. to control goosegrass (Eleusine indica (L.) Gaertn.) (Figliola et al., 1988). Dew periods of about $12 \mathrm{~h}$ have been reported for other bioherbicide agents such as Colletotrichum gloeosporioides (Penz.) Penz. \& Sacc. in Penz. f. sp aeschynomene (TeBeest \& Templeton, 1978), Colletotrichum coccodes (Wallr.) Hughes (Anderson \& Walker, 1985), and Fusarium lateritium Nees:Fr. (Boyette \& Walker, 1985).

Kadir (1997) developed Dactylaria higginsii (Luttrell) M.B. Ellis as a bioherbicide to control purple nutsedge (Cyperus rotundus L.). The fungus was highly pathogenic to 4to 6-leaf stage of purple nutsedge plants in a temperature range of 20 to $30^{\circ} \mathrm{C}$ and as little as 12 h-dew period was sufficient to cause high levels of disease. At these temperatures and 
dew period, this fungus provided excellent control of young purple nutsedge plants under greenhouse and field conditions. Temperatures in the range of 20 to $30^{\circ} \mathrm{C}$ and dew peirods from 6- to 12- h occur commonly during the early period of the cropping season in warm, temperate regions where purple nutsedge is a serious problem.

The dew period and temperature conditions chosen for this study were based on the optima reported for the different bioherbicidal fungi discussed above. When provided $12 \mathrm{~h}$ of dew at $28^{\circ} \mathrm{C}$, each pathogen and the mixture of the three pathogens controlled the tested weedy grass species. Hence, temperature and dew period requirements of $D$. gigantea, $E$. longirostratum, and E. rostratum, and the pathogen mixture are within a range that occur normally under field conditions. All weedy grasses tested in this study were highly susceptible to the three pathogens, and the pathogen mixture (100\% disease incidence) in the greenhouse. Guineagrass, southern sandbur, Texas panicum, and yellow foxtail were completely killed (100\% disease severity) while large crabgrass, crowfootgrass, and johnsongrass had significantly high levels of disease with DS ranging from 82.5 to $95.0 \%$, when inoculated with individual pathogens or a mixture of three pathogens. Drechslera gigantea, E. longirostratum, E. rostratum, and a mixture of the three pathogens almost completely killed large crabgrass, crowfootgrass, johnsongrass, guineagrass, Texas panicum, southern sandbur, and yellow foxtail. Although the individual pathogens were equally effective as the pathogen mixture, use of the pathogen mixture would compensate for any possible failure of a single pathogen. Also, availability of the three pathogens to control the above-mentioned weedy grasses allows choice of a pathogen, should resistance develop to any one of the three pathogens. 


\section{CHAPTER IV \\ EVALUATION OF THE HOST RANGES OF Drechslera gigantea, Exserohilum longirostratum, AND E. rostratum.}

\section{Introduction}

Microorganisms released into the environment may raise concern because of their potential to establish and spread. However, it is usually difficult to maintain the population of an introduced microorganism at a density greater than what occurs in nature, or to establish a microorganism where it does not already occur (Garrett, 1965, Baker \& Cook, 1974). Populations of microorganisms applied to the environment commonly decline to a density normally sustainable in that environment. This often results in undetectable levels of introduced organism (Podgwaite, 1981). Populations of plant-associated microorganisms introduced as postemergence biocontrol agents will decline to background levels when the host plant dies (Cook et al., 1996). The organism must be applied again when required. However, a pathogen applied as a bioherbicidal agent does have the potential to harm a susceptible crop plant related to the target weed, if the crop is grown within the range of dissemination of the bioherbicidal pathogen.

In the selection of agents for the biological control of weeds, it is important to demonstrate that the organisms selected are sufficiently specific to the weed host and are nonpathogenic to plants of economic importance. Wapshere (1974) compared the various methods that had been used to select plants for host range evaluation. They consisted of two 
general types: (a) the crop-testing method where a large number of crop plants were exposed to the organism and (b) the biologically relevant method proposed by Harris \& Zwolfer (1968) in which one examined the biology, specificity, and evolutionary relationships between the agent and its host. Wapshere (1974) suggested a testing strategy, essentially based on the phylogenetic relationships of the weed, combining some of the safety of cropplant testing method with the relevance of more biologically meaningful methods. The strategy is based on a centrifugal-phylogenetic testing method, in which a selection of plants from those most closely related taxonomically to the weed species to those more distantly related are exposed to the bioherbicidal agent. Then, more distantly related plant species are successively tested until the host-range has been adequately circumscribed. As a safeguard against failure of the centrifugal method, cultivated plants selected by the following criteria should be included in the tests: 1) cultivated plants taxonomically related to the weed, 2) cultivated plants for which little or no mycological information available, 3) cultivated plants which have evolved apart from the biological control agent, or for geographic or climatic reasons have not been extensively exposed to the agent, 4) cultivated plants known to be attacked by organisms closely related to the biological control agent under investigation, and 5) any plants on which the organism has previously been recorded.

The host range of a fungal pathogen, as determined by artificial inoculation, may be much wider than observed in nature (Watson, 1985). This has been demonstrated for cereal rusts and mildews, which can attack a wide range of members of Poaceae under experimental conditions. However, these fungi have a very narrow and specific host-range in the field (Barrett, 1983). Against this conceptual background, the objective of this study was to determine the host-range of Drechslera gigantea (Heald \& Wolf) Ito, Exserohilum 
longirostratum (Subram.) Sivan., E. rostratum (Drechsler) Leonard \& Suggs., and a mixture of these pathogens.

\section{Materials and Methods}

\section{Production of Crop Plants}

Pathogenicity of $D$. gigantea, E. longirostratum, E. rostratum, and a mixture of these pathogens was tested on selected crop plants. Seedlings of crop species to be tested were raised from seeds in $10-\mathrm{cm}$-diam $\times 10.63-\mathrm{cm}$-tall plastic pots containing a commercial potting medium (Metromix 300; Scott's Sierra Horticultural Products Co., Marysville, $\mathrm{OH}$ ). The seedlings were maintained in a greenhouse and watered to soil saturation as required.

\section{Inoculum Production}

A small mycelial plug from a stock culture was aseptically transferred to fresh modified V8 agar (200 $\mathrm{ml} \mathrm{V8} \mathrm{juice,} 800 \mathrm{ml}$ water, $14 \mathrm{~g}$ agar; Dhingra \& Sinclair, 1995). The plates were incubated for $1-2$ days $\left(25^{\circ} \mathrm{C}, 12 \mathrm{~h} / 12 \mathrm{~h} \mathrm{light} /\right.$ dark, $\left.35 \pm 5 \mu \mathrm{E} / \mathrm{m}^{2} / \mathrm{s}\right)$ until adequate colony growth was observed. Mycelial plugs from the margins of this growing young colony were transferred to fresh V8 agar plates ( 5 plugs per plate). The plates were incubated as above for 2 weeks. Conidia were harvested after each plate was flooded with $10 \mathrm{ml}$ deionized water and the spores dislodged with a rubber spatula. The conidial suspension was then passed through a single layer of cheesecloth. The concentration of spores was determined with a haemocytometer and adjusted to $5 \times 10^{5}$ spores $/ \mathrm{ml}$ by dilution in water. 


\section{Host-range Determination}

Host-range determinations were done for the three individual pathogens, D. gigantea, E. longirostratum, E. rostratum, and a mixture of all these pathogens. The host-range test included several grasses that are problematic weeds in Florida, crop plants that are commonly reported as hosts to other species of Drechslera and Exserohilum and crop plants of economic importance in Florida.

They were: Zea mays L. (corn), Sorghum bicolor L. Moench (sorghum), Avena sativa L. (oat), Triticum aestivum L.(wheat), and Secale cereale L. (rye). Different cultivars of these crops were included. The following economically important crop plants grown in Florida were tested: Beta vulgaris L. (beet), Brassica oleracea L. var. botrytis L. (broccoli, cauliflower), B. oleracea L. var. capitata L. (cabbage), B. oleracea L. var. acephala DC. (collards), B. oleracea L. var. gemmifera DC. (brussel sprouts), B. rapa L. (turnip), Daucus carota L. subsp. sativus (Hoffm.) Arcang. (carrot), Coriandrum sativum L. (cilantro, parsley), Cichorium endivia L. (endive), Lactuca sativa L. var. capitata L. (head lettuce), L. sativa L. var. longifolia Lam. (romaine lettuce), B. juncea (L.) Czern. (Indian mustard), Allium cepa L. (onion), Abelmoschus esculentus (L.) Moench (okra), Raphanus sativus L. (radish), Spinacia oleracea L. (spinach), Pisum sativum L. (pea), Arachis hypogaea L. (peanut), Phaseolus vulgaris L. (bean), Vigna unguiculata (L.) Walp. (cowpea, black eye), Cucumis sativus L. (cucumber), Solanum melongena L. (egg plant), Capsicum annuum L. (green pepper), Cucurbita pepo L. (squash, Zucchini), Citrullus lanatus (Thunb.) Matsum. \& Nakai (watermelon), Cucumis melo L. var. cantalupensis Naudin (cantaloupe), Lycopersicon esculentum Mill. (tomato), and Zea mays L. (sweet corn). Also, the pathogens were tested on Citrus sinensis (L.) Osbeck (orange), and C. paradisi Macfad. (grapefruit), 
crops in which the pathogens will be eventually applied as bioherbicides. A total of 50 plant species from 11 families were included. They belonged to the following families: Apiaceae, Asteraceae, Brassicaceae, Chenopodiaceae, Cucurbitaceae, Fabaceae, Liliaceae, Malvaceae, Poaceae, Rutaceae, and Solanaceae.

The following is a list of sources of seeds of the crop plants tested: beet, carrot, onion, radish, and sweet corn (Burpee, W. Atlee Burpee \& Co., Warminster, PA); cilantro, spinach, cucumber, and pepper (Ferry Morse, Ferry-Morse Seed Co., Fulton, KY); broccoli, collards, endive, lettuce, okra, parsley, tomato, turnip, and squash (Green Valley, The Page Seed Co., Greene, N.Y.); cantaloupe, cabbage, cauliflower, and mustard (Sawan Seeds Inc., Pelham, GA); pea, beans, cowpea, peanut (cv. Jumbo Virginia) (Dr. Purcifull, Univ. of Florida (UF), Gainesville (GNV), FL); peanuts (cv. Florunner, Southern runner, Georgia green) (Dr. Kucharek, UF, GNV, FL); perennial peanut (Dr. Kretschmer, UF, Fort Pierce, FL); oat and rye (Dr. Berger, UF, GNV, FL); and sorghum and corn (Dr. Pring, UF, GNV, FL). Orange and grapefruit plants were provided by Dr. Megh Singh, UF, Lake Alfred, FL.

Two to five plants of a single crop species were grown in each pot. The number of plants and age of the plant species tested varied depending on the growth habit of the species and plant size suitable for inoculation. Most plants were sprayed until runoff, when they were 1- to 2-week old, with aqueous suspensions of inoculum containing 2 to $5 \times 10^{5}$ spores per ml plus $0.5 \%$ Metamucil $^{\circledast}$ (Procter \& Gamble, Cincinnati, OH). The latter was used as a humectant. The individual pathogens as well as a mixture of all three pathogens $(1: 1: 1 \mathrm{v} / \mathrm{v})$ were tested. Noninoculated control plants were sprayed with $0.5 \%$ Metamucil in water. Susceptible weed hosts were included with each batch of test plants. Inoculated plants were held in a dew chamber in the dark for $12 \mathrm{~h}\left(28^{\circ} \mathrm{C}, 100 \% \mathrm{RH}\right)$. The plants were then moved 
to a greenhouse and observed for disease development over a period of 4 weeks. Similarly, selected crop species ( 25 species from 9 families) were sprayed with the pathogen mixture alone in an oil-based emulsion as carrier (Sunspray ${ }^{\circledR} 6 \mathrm{E} 80 \mathrm{ml}$, paraffin oil $20 \mathrm{ml}, 100 \mathrm{ml}$ spores in water). Noninoculated control plants were sprayed with the emulsion alone.

\section{Disease Assessment}

The disease reactions of host plants were assessed on the basis of appearance of diease symptoms: Plants that developed typical disease symptoms characteristic for the pathogens being tested were considered to be susceptible. Those which developed symptoms such as minute flecks or noncoalescing/nonexpanding lesions, which disappeared over time, were considered to be resistant. Nonsymptomatic plants were considered to be immune to the pathogens.

\section{Results}

In repeated experiments, each pathogen (D. gigantea, E. longirostratum, E. rostratum), and the pathogen mixture caused disease on all weedy grass species tested. Important crop plants in the family Poaceae, which are reportedly hosts to pathogens of the genera Drechslera and Exserohilum, were resistant to the pathogens tested individually or as a mixture. However, the cereal crops sorghum, oat, wheat, and rye developed few chlorotic leaf lesions, surrounded by dark pink or brown border. In corn and sweet corn, the leaf lesions did not have borders and appeared more like "chlorotic halos" (Figure 4.1). These lesions formed in response to inoculation with the pathogen mixture within $24 \mathrm{~h}$ after inoculation. These lesions did not expand further and they eventually disappeared over time 
with plant growth, which was indicative of a resistance response. In histological examination of such lesions, extensive accumulation of lipophylic, dark pink or brown colored compounds occurred in and around sites of pathogen ingress.

Significant cell death and tissue damage were associated with the lesions induced by the pathogen mixture on guineagrass, the weed host, within 24 to $48 \mathrm{~h}$ after inoculation (Figure 4-2). All nonhost cereal crops inoculated with the pathogen mixture exhibited extensive accumulation of dark pink to orange- or brown-colored phytoalexin-like compounds within the host tissue in and around sites of attempted penetration by the fungus. Unlike in guineagrass, the weed host, the nonhost crop plants in Poaceae did not have any significant cell collapse or cell death associated with the accumulation of the compounds (Figures 4.3-4.7).

All other economically important nonhost crop plants in families other than Poaceae tested were immune to all three pathogens and the pathogen mixture (Table 4-1). Also, the crop plant species tested were not affected by the emulsion-based inoculum preparation of the pathogen mixture (Table 4-2). Thus, D. gigantea, E. longirostratum, E. rostratum, and a mixture of all the three pathogens were nonpathogenic to the crop species tested.

\section{Discussion}

Evaluation of the host-range is an important step in the determination of the safety of fungal pathogens to be used as bioherbicides. The pathogens should not infect crop species and other nontarget plants grown in the region where the pathogens are intended to be used to control target weeds. In general, all known fungal plant pathogens grow preferentially or exclusively on a limited number of hosts. There are many factors that affect 
Table 4-1. Host reaction to inoculation with Drechslera gigantea (Dg), Exserohilum longirostratum (El), Exserohilum rostratum (Er), and a mixture of these pathogens (1:1:1 $\mathrm{v} / \mathrm{v}$ ).

\begin{tabular}{|c|c|c|c|c|c|}
\hline \multirow[t]{2}{*}{ Host } & \multirow{2}{*}{$\begin{array}{l}\text { Variety } \\
\text { (or) } \\
\text { Cultivar }\end{array}$} & \multicolumn{4}{|c|}{ Reaction $^{a}$} \\
\hline & & Dg & $\mathrm{El}$ & $\mathrm{Er}$ & Mix \\
\hline Large crabgrass & & $S$ & $\mathrm{~S}$ & $\mathrm{~S}$ & $S$ \\
\hline Crowfootgrass & & $\mathrm{S}$ & S & $\mathrm{S}$ & S \\
\hline Johnsongrass & & $S$ & S & S & $\mathrm{S}$ \\
\hline Guineagrass & & $S$ & $\mathrm{~S}$ & $\mathrm{~S}$ & S \\
\hline Southern sandbur & & $\mathrm{S}$ & $\mathrm{S}$ & S & S \\
\hline Texas panicum & & $\mathrm{S}$ & $\mathrm{S}$ & $\mathrm{S}$ & S \\
\hline Yellow foxtail & & S & $\mathrm{S}$ & $\mathrm{S}$ & S \\
\hline Green foxtail & & $\mathrm{S}$ & $\mathrm{S}$ & $S$ & $\mathrm{~S}$ \\
\hline Vaseygrass & & $\mathrm{S}$ & $\mathrm{S}$ & S & $\mathrm{S}$ \\
\hline Natalgrass & & $\mathrm{S}$ & $\mathrm{S}$ & $\mathrm{S}$ & $S$ \\
\hline Napiergrass & & $\mathrm{S}$ & $\mathrm{S}$ & $\mathrm{S}$ & S \\
\hline Bermudagrass & & S & S & S & $S$ \\
\hline Torpedograss & & S & $\mathrm{S}$ & $\mathrm{S}$ & $\mathrm{S}$ \\
\hline Bahiagrass & b & $\mathrm{S}$ & $\mathrm{S}$ & $\mathrm{S}$ & $\mathrm{S}$ \\
\hline Bahiagrass & Pensacola & I & I & I & I \\
\hline
\end{tabular}

${ }^{\mathrm{a}} \mathrm{I}=$ Immune; $\mathrm{S}=$ Susceptible; $\mathrm{R}=$ Resistant (few lesions on foliage with no lesion expansion). Inoculation conditions: 3-5 plants per pot, three replicates, inoculum level of $2 \times 10^{5}$ spores $/ \mathrm{ml}, 0.5 \%$ Metamucil as a humectant, and given a $12 \mathrm{~h}$ dewperiod at $28^{\circ} \mathrm{C}$. $\mathrm{b}=$ Cultivar name is not known. 


\begin{tabular}{|c|c|c|c|c|c|}
\hline \multirow[t]{2}{*}{ Host } & \multirow{2}{*}{$\begin{array}{l}\text { Variety } \\
\text { (or) } \\
\text { Cultivar }\end{array}$} & \multicolumn{4}{|c|}{ Reaction $^{2}$} \\
\hline & & $\mathrm{Dg}$ & El & $\mathrm{Er}$ & Mix \\
\hline Beet & Detroit Dark Red & I & I & I & I \\
\hline Broccoli & Green Sprouting & I & I & I & I \\
\hline Cabbage & $-b$ & I & I & I & I \\
\hline Carrot & Short 'n' Sweet & I & I & I & I \\
\hline Cauliflower & $-b$ & I & I & I & I \\
\hline Cilantro & Culinary & I & I & I & I \\
\hline Collards & Georgia Southern & I & I & I & I \\
\hline Endive & Batavian Full Heart & I & I & I & I \\
\hline Lettuce-Head & Great Lakes & I & I & I & I \\
\hline Lettuce-Romaine & Cos or Romaine & I & I & I & I \\
\hline Mustard & $-b$ & I & I & I & I \\
\hline Okra & Clemson Spineless & I & I & I & I \\
\hline Onion & Evergreen Longwhite & I & I & I & I \\
\hline Parsley & Moss Curled & I & I & I & I \\
\hline Radish & Crimson Giant & I & I & I & I \\
\hline
\end{tabular}

${ }^{2} \mathrm{I}=$ Immune; $\mathrm{S}=$ Susceptible; $\mathrm{R}=$ Resistant (few lesions on foliage with no lesion expansion). Inoculation conditions: 3-5 plants per pot, three replicates, inoculum level of $5 \times 10^{5}$ spores $/ \mathrm{ml}, 0.5 \%$ Metamucil as a humectant, and given a $12 \mathrm{~h}$ dewperiod at $28^{\circ} \mathrm{C}$. $\mathrm{b}=$ Cultivar name is not known. 


\begin{tabular}{|c|c|c|c|c|c|}
\hline \multirow[t]{2}{*}{ Host } & \multirow{2}{*}{$\begin{array}{l}\text { Variety } \\
\text { (or) } \\
\text { Cultivar }\end{array}$} & \multicolumn{4}{|c|}{ Reaction $^{a}$} \\
\hline & & Dg & El & $\mathrm{Er}$ & Mix \\
\hline Spinach & Bloomsdale & I & I & I & I \\
\hline Sweet Corn & Early Sunglow & $\mathrm{R}$ & $\mathrm{R}$ & $\mathrm{R}$ & $\mathrm{R}$ \\
\hline Tomato & Rutgers & $\mathrm{R}$ & $\mathrm{R}$ & $\mathrm{R}$ & $\mathrm{R}$ \\
\hline Turnip & Nabo & I & I & I & I \\
\hline Pea & Little Marvel & I & I & I & I \\
\hline Beans, Lima & Top Crop & I & I & I & I \\
\hline Cantaloupe & $-b$ & I & I & I & I \\
\hline Cucumber & Slicing & I & I & I & I \\
\hline \multirow[t]{4}{*}{ Peanut } & Jumbo Virginia & I & I & I & I \\
\hline & Florunner & I & I & I & I \\
\hline & Southern Runner & I & I & I & I \\
\hline & Georgia Green & I & I & I & I \\
\hline Perennial peanut & A legume cover crop & I & I & I & I \\
\hline
\end{tabular}

${ }^{a} \mathrm{I}=$ Immune; $\mathrm{S}=$ Susceptible; $\mathrm{R}=$ Resistant (few lesions on foliage with no lesion expansion). Inoculation conditions: 3-5 plants per pot, three replicates, inoculum level of $5 \times 10^{5}$ spores $/ \mathrm{ml}, 0.5 \%$ Metamucil as a humectant, and given a $12 \mathrm{~h}$ dewperiod at $28^{\circ} \mathrm{C}$. ${ }^{\mathrm{b}}=$ Cultivar name is not known. 


\begin{tabular}{ccc}
\hline Host & Variety & Reaction \\
(or) & Cultivar & \\
&
\end{tabular}

\begin{tabular}{|c|c|c|c|c|c|}
\hline & & $\mathrm{Dg}$ & E1 & $\mathrm{Er}$ & Mix \\
\hline Pepper, Hot & Jalapeno & I & I & I & I \\
\hline \multicolumn{5}{|l|}{ (Crookneck) } & I \\
\hline Cowpea & Black Eye & I & I & I & I \\
\hline Bermudagrass & Lawn type & $\mathrm{S}$ & $\mathrm{S}$ & $\mathrm{S}$ & $\mathrm{S}$ \\
\hline \multirow[t]{2}{*}{ Citrus } & Valencia & I & I & I & I \\
\hline & Grapefruit & I & I & I & I \\
\hline \multirow[t]{2}{*}{ Wheat } & FL 301 & $\mathrm{R}$ & $\mathrm{R}$ & $\mathrm{R}$ & $\mathrm{R}$ \\
\hline & Morey & $\mathrm{R}$ & $\mathrm{R}$ & $\mathrm{R}$ & $\mathrm{R}$ \\
\hline Wheat/Secale Cross & Sunland Triticale & $\mathrm{R}$ & $\mathrm{R}$ & $\mathrm{R}$ & $\mathrm{R}$ \\
\hline \multirow[t]{2}{*}{ Oat } & FL 502 & $\mathrm{R}$ & $\mathrm{R}$ & $\mathrm{R}$ & $\mathrm{R}$ \\
\hline & Fulghum & $\mathrm{R}$ & $\mathrm{R}$ & $\mathrm{R}$ & $\mathrm{R}$ \\
\hline \multirow[t]{6}{*}{ Sorghum } & DK 58 & $\mathrm{R}$ & $\mathrm{R}$ & $\mathrm{R}$ & $\mathrm{R}$ \\
\hline & DK 104 & $\mathrm{R}$ & $\mathrm{R}$ & $\mathrm{R}$ & $\mathrm{R}$ \\
\hline & TX 398 & $\mathrm{R}$ & $\mathrm{R}$ & $\mathrm{R}$ & $\mathrm{R}$ \\
\hline & TX 7000 & $\mathrm{R}$ & $\mathrm{R}$ & $\mathrm{R}$ & $\mathrm{R}$ \\
\hline & TX 430 & $\mathrm{R}$ & $\mathrm{R}$ & $\mathrm{R}$ & $\mathrm{R}$ \\
\hline & IS1112C & $\mathrm{R}$ & $\mathrm{R}$ & $\mathrm{R}$ & $\mathrm{R}$ \\
\hline
\end{tabular}

${ }^{\mathrm{a}} \mathrm{I}=$ Immune; $\mathrm{S}=$ Susceptible; $\mathrm{R}=$ Resistant (few lesions on foliage with no lesion expansion). Inoculation conditions: 3-5 plants per pot, three replicates, inoculum level of $5 \times 10^{5}$ spores $/ \mathrm{ml}, 0.5 \%$ Metamucil as a humectant, and given a $12 \mathrm{~h}$ dewperiod at $28^{\circ} \mathrm{C}$.

${ }^{\mathrm{b}}=$ Cultivar name is not known. 


\begin{tabular}{|c|c|c|c|c|c|}
\hline \multirow[t]{2}{*}{ Host } & \multirow{2}{*}{$\begin{array}{l}\text { Variety } \\
\text { (or) } \\
\text { Cultivar }\end{array}$} & \multicolumn{4}{|c|}{ Reaction $^{a}$} \\
\hline & & Dg & El & $\mathrm{Er}$ & Mix \\
\hline \multirow[t]{2}{*}{ Rye } & Graze Master & $\mathrm{R}$ & $\mathrm{R}$ & $\mathrm{R}$ & $\mathrm{R}$ \\
\hline & Wrens Abruzzi & $\mathrm{R}$ & $\mathrm{R}$ & $\mathrm{R}$ & $\mathrm{R}$ \\
\hline \multirow[t]{6}{*}{ Corn } & B37(T) & $\mathrm{R}$ & $\mathrm{R}$ & $\mathrm{R}$ & $\mathrm{R}$ \\
\hline & A619(N) & $\mathrm{R}$ & $\mathrm{R}$ & $\mathrm{R}$ & $\mathrm{R}$ \\
\hline & WF9(T) & $\mathrm{R}$ & $\mathrm{R}$ & $\mathrm{R}$ & $\mathrm{R}$ \\
\hline & W64A(T) x A632 & $\mathrm{R}$ & $\mathrm{R}$ & $\mathrm{R}$ & $\mathrm{R}$ \\
\hline & A632(N) & $\mathrm{R}$ & $\mathrm{R}$ & $\mathrm{R}$ & $\mathrm{R}$ \\
\hline & A632(RFRF) & $\mathrm{R}$ & $\mathrm{R}$ & $\mathrm{R}$ & $\mathrm{R}$ \\
\hline
\end{tabular}

${ }^{\mathrm{a}} \mathrm{I}=$ Immune; $\mathrm{S}=$ Susceptible; $\mathrm{R}=$ Resistant (few lesions on foliage with no lesion expansion). Inoculation conditions: 3-5 plants per pot, three replicates, inoculum level of $5 \times 10^{5}$ spores $/ \mathrm{ml}, 0.5 \%$ Metamucil as a humectant, and given a $12 \mathrm{~h}$ dewperiod at $28^{\circ} \mathrm{C}$.

$\mathrm{b}=$ Cultivar name is not known. 
Table 4-2. Host reaction to inoculation with a mixture of Drechslera gigantea, Exserohilum longirostratum, and Exserohilum rostratum (1:1:1 v/v) in an emulsion-based inoculum.

\begin{tabular}{ccc}
\hline Host & Variety & Reaction \\
& (or) & \\
& Cultivar & \\
&
\end{tabular}

\begin{tabular}{lll}
\hline & & Mix \\
\hline Beet & Detroit Dark Red & I \\
Cabbage & $-{ }^{b}$ & I \\
Carrot & Short 'n Sweet & I \\
Cauliflower & $-{ }^{\text {b }}$ & I \\
Radish & Crimson Giant & I \\
Tomato & Rutgers & I \\
Turnip & Nabo & I \\
Pea & Little Marvel & I \\
Beans, Lima & Top Crop & I \\
Cantaloupe & $-{ }^{b}$ & I \\
Cucumber & Poinsette & I \\
Squash & Early Summer & I \\
(Crookneck) & & \\
Cowpea & Black Eye & I \\
Citrus & Valencia & I \\
& Grapefruit & I \\
\hline
\end{tabular}

${ }^{a} \mathrm{I}=$ Immune; $\mathrm{S}=$ Susceptible; $\mathrm{R}=$ Resistant (few lesions on foliage with no lesion expansion). Inoculation conditions: 2-5 plants per pot, three replicates, inoculum level of $5 \times 10^{5}$ spores $/ \mathrm{ml}$, applied in $40 \%$ emulsion (Sunspray ${ }^{8} 6 \mathrm{E} 80 \mathrm{ml}$, paraffin oil $20 \mathrm{ml}$, spores in water $100 \mathrm{ml}$ ), and given a $12 \mathrm{~h}$ dewperiod at $28^{\circ} \mathrm{C}$.

${ }^{b}=$ Cultivar name is not known. 


\begin{tabular}{lll}
\hline Host & $\begin{array}{l}\text { Variety } \\
\text { (or) } \\
\text { Cultivar }\end{array}$ & Reaction ${ }^{2}$ \\
\hline Wheat & Morey & Mix \\
Sorghum & DK 104 & R \\
& TX 398 & R \\
Zucchini & IS1112C & R \\
Watermelon & Black Beauty & R \\
Brussel Sprout & Llack Diamond & I \\
Eggplant & Black Beauty & I \\
Sunflower & Giant Greystripe & I \\
\hline
\end{tabular}

a $\mathrm{I}=$ Immune; $\mathrm{S}=$ Susceptible; $\mathrm{R}=$ Resistant (few lesions on foliage with no lesion expansion). Inoculation conditions: $2-5$ plants per pot, three replicates, inoculum level of $5 \times 10^{5}$ spores $/ \mathrm{ml}$, applied in $40 \%$ emulsion (Sunspray ${ }^{8} 6 \mathrm{E} 80 \mathrm{ml}$, paraffin oil $20 \mathrm{ml}$, spores in water $100 \mathrm{ml}$ ), and given a $12 \mathrm{~h}$ dewperiod at $28^{\circ} \mathrm{C}$.

$\mathrm{b}=$ Cultivar name is not known. 
A.

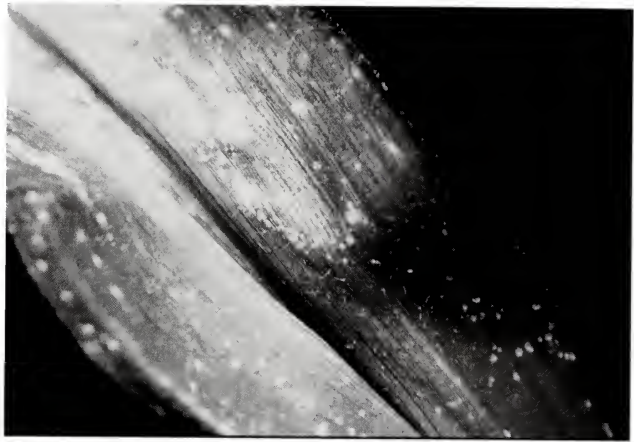

B.

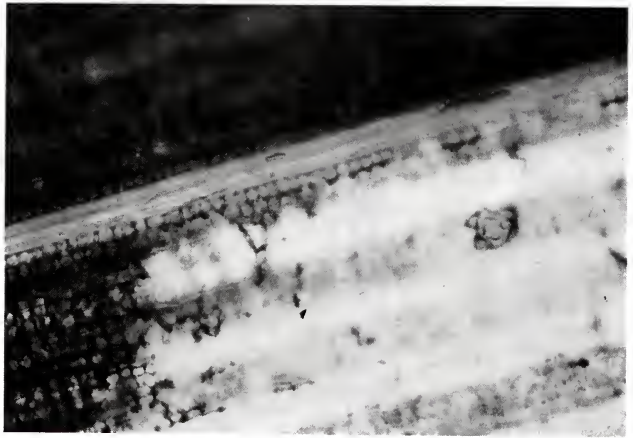

Figure 4-1. Sweet corn (cv. Early Sunglow, nonhost) leaf showing chlorotic lesions upon inoculation with a mixture of Drechslera gigantea, Exserohilum longirostratum, and $E$. rostratum (A). Histological view of an individual chlorotic lesion on sweet corn (cv. Early Sunglow, nonhost) caused by inoculation with a mixture of Drechslera gigantea, Exserohilum longirostratum, and E. rostratum (B). 


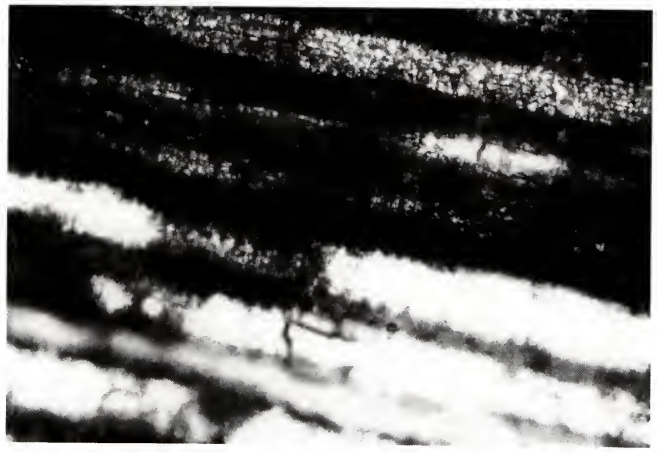

Figure 4-2. Guineagrass leaf (weed host) showing lesions with extensive tissue damage (lower half of the figure) upon inoculation with a mixture of Drechslera gigantea, Exserohilum longirostratum, and E. rostratum. 
A.

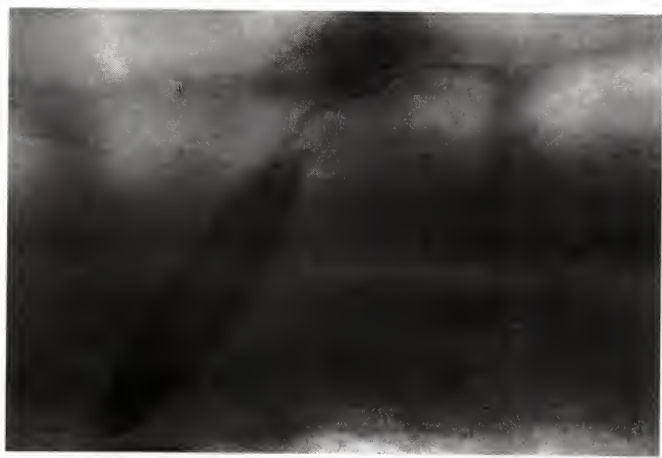

B.

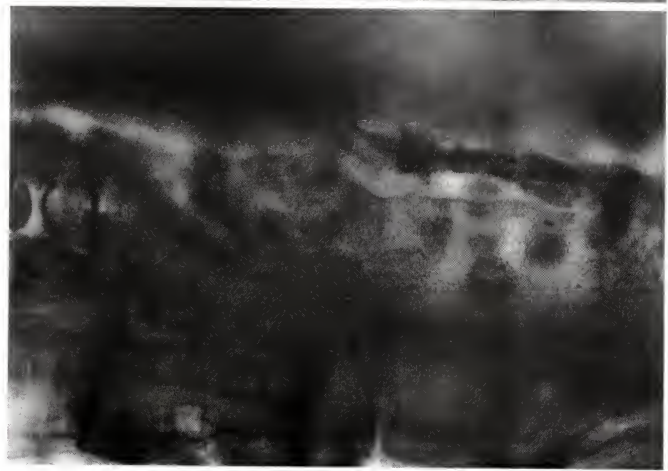

Figure 4-3. Accumulation of dark pink to brown colored compounds in and around the site of pathogen ingress in sorghum leaf (cv. DK 404, nonhost) inoculated with a mixture of Drechslera gigantea, Exserohilum longirostratum, and E. rostratum (A). A closer view of individual cells containing minute lipophylic, dark pink spherical bodies) in sorghum leaf (cv. DK 404, nonhost) inoculated with a mixture of Drechslera gigantea, Exserohilum longirostratum, and E. rostratum (B). 
A.
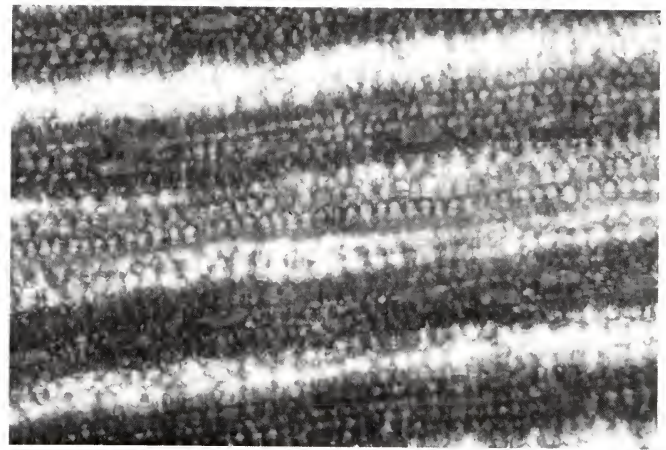

B.
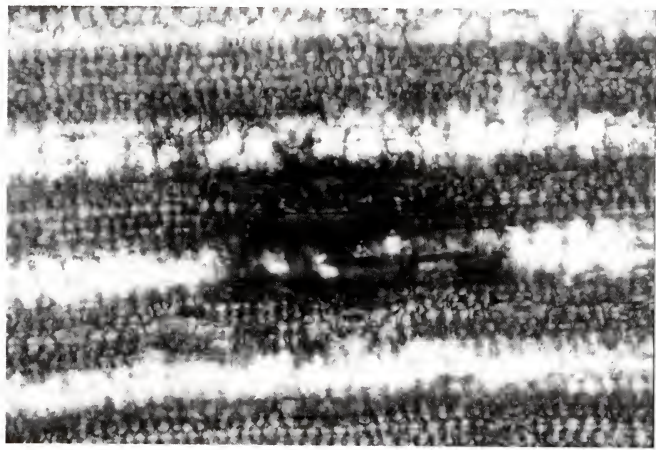

Figure 4-4. Histological view of a noninoculated, healthy sorghum leaf (cv. IS1112C, nonhost) (A). Cells of sorghum leaf (cv. IS1112C, nonhost) showing accumulation of lipophylic, dark brown colored compounds in and around the sites of pathogen ingress upon inoculation with a mixture of Drechslera gigantea, Exserohilum longirostratum, and $E$. rostratum (B). 
A.

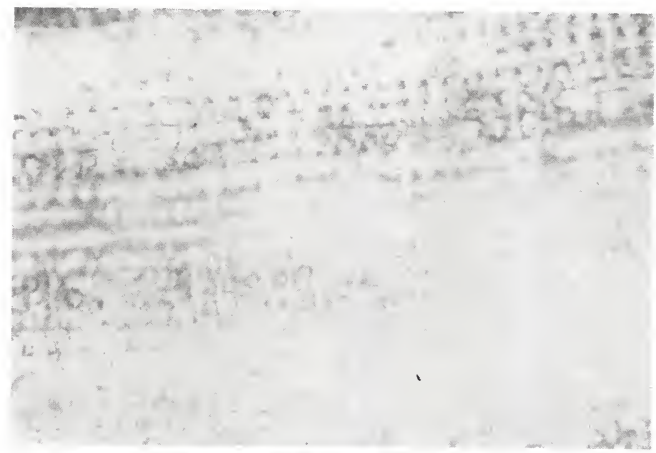

B.

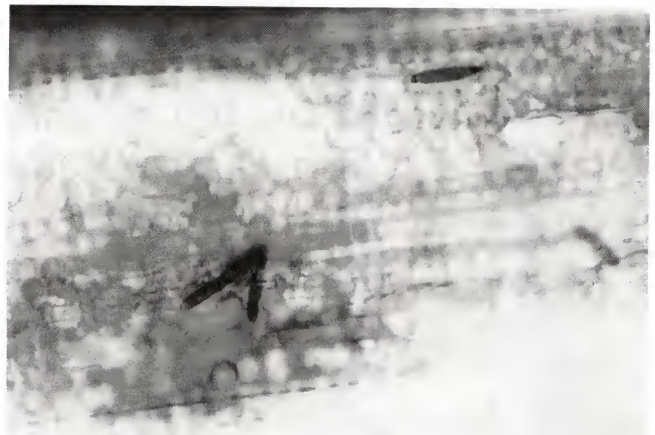

Figure 4-5. Histological view of a noninoculated healthy oat leaf (cv. FL 502, nonhost) (A). Cells of oat leaf (cv. FL 502, nonhost) showing accumulation of lipophylic, dark pink to brown colored compounds in and around the sites of pathogen ingress upon inoculation with a mixture of Drechslera gigantea, Exserohilum longirostratum, and E. rostratum (B). 
A.

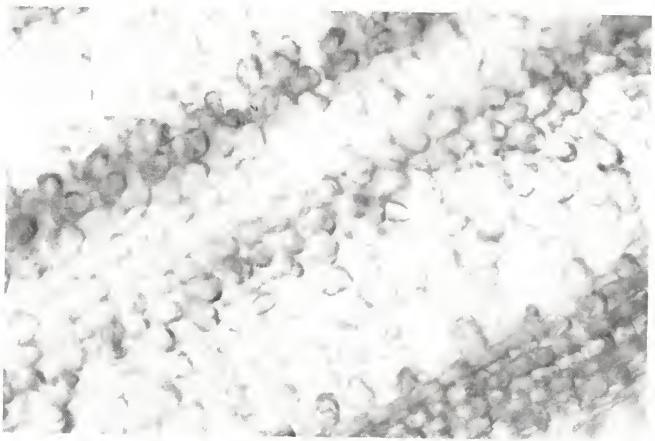

B.

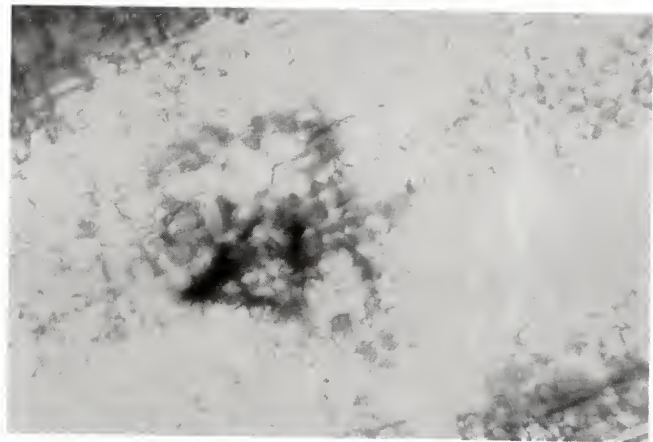

Figure 4-6. Histological examination of a noninoculated, healthy rye leaf (cv. Wrens Abruzzi, nonhost) (A). Cells of rye leaf (cv. Wrens Abruzzi, nonhost) showing accumulation of lipophylic, dark orange to brown colored compounds in and around the sites of pathogen ingress upon inoculation with a mixture of Drechslera gigantea, Exserohilum longirostratum, and E. rostratum (B). 
A.

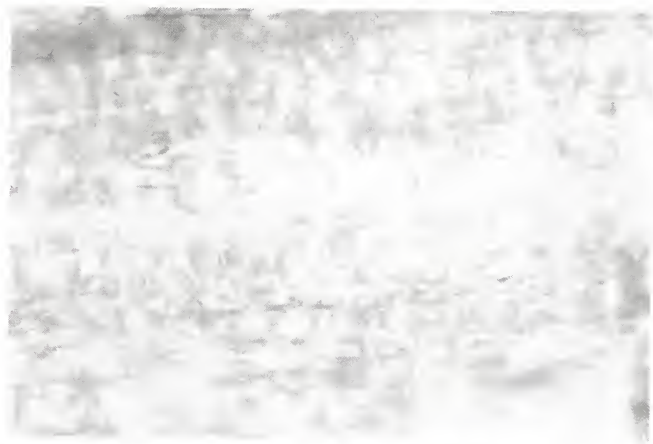

B.

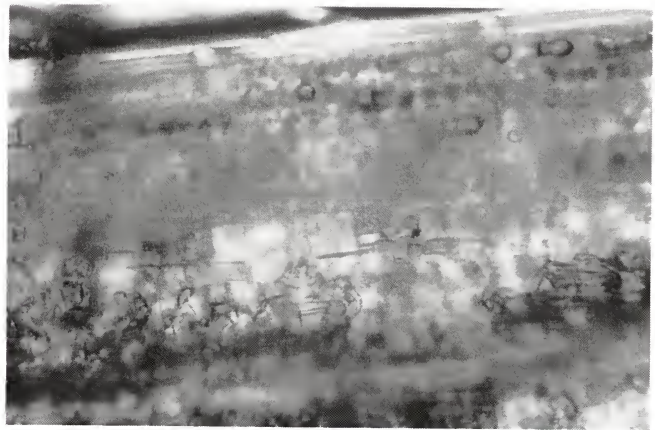

Figure 4-7. Histological view of a noninoculated, healthy wheat leaf (cv. Morey, nonhost) (A). Cells of wheat leaf (cv. Morey, nonhost) showing accumulation of lipophylic, dark orange to brown colored compunds in and around the sites of pathogen ingress upon inoculation with a mixture of Drechslera gigantea, Exserohilum longirostratum, and E. rostratum. 
and restrict the host range of a pathogen.

Plants resist pathogen attack or slow down the growth of a pathogen by mobilizing a variety of biochemical and molecular defenses (Bowles, 1990). These responses include ion fluxes across the plant plasma membrane, the generation of highly reactive oxygen species (the oxidative burst), phosphorylation of specific proteins, activation of enzymes involved in strengthening of the cell wall, transcriptional activation of numerous defense genes, induction of phytoalexins, localized cell death at the infection sites (the hypersensitive response [HR]), and the induction of systemic acquired resistance in distal plant organs.

Induced or acquired resistance against biotrophic pathogens in barley and other grasses have been well studied (Steiner \& Schonbeck, 1995). Induced resistance against necrotrophic pathogens in monocotyledonous plants have not been examined in great detail, except in the rice-Pyricularia oryzae Cav. system (Arase \& Fujita, 1992; Smith \& Metraux, 1991). Recently, Jorgensen et al. (1996) demonstrated that the severity of barley net blotch caused by a necrotrophic pathogen, Drechslera teres (Sacc.) Shoemaker and hyphal growth of the fungus in the host tissue can be significantly reduced. This occurred when barley leaves were pretreated with conidial suspensions of either of two nonbarley pathogens, Bipolaris maydis (Nisik. \& Miyake) Shoemaker from maize or Septoria nodorum (Berk.) Berk. from wheat. The pretreatment with nonpathogens resulted in reduced size and number of lesions caused by the pathogen, D. teres. The inhibition of growth of the pathogen was apparently linked to an enhancement of multicellular hypersensitive responses primarily manifested during penetration by $D$. teres. Such responses were also seen in fully susceptible (non-treated) control leaves of barley, but they were inadequate to stop the progress of the pathogen in the host (Jorgensen et al., 1998). 
In this study, the host-range of Drechslera gigantea, Exserohilum longirostratum, and $E$. rostratum were confined to only some weedy grasses tested. These fungi did not infect other crop species tested. A mixture of the three pathogens was also tested in the same manner and found to be equally nonpathogenic and therefore safe to the crop species tested. However, the cereal crops sorghum, oat, wheat, and rye did develop a few noncoalescing leaf lesions within $24 \mathrm{~h}$ after inoculation that appeared as "chlorotic halos". The "chlorotic halo" lesion phenotype is associated with resistance response in corn (Carson, 1995). The chlorotic lesion phenotype is retained by resistant corn until plant senescence. This lesion type was characterized by infection points that developed a distinct dark orange brown pigment and later was surrounded by a circular chlorotic halo. In susceptible corn, chlorotic lesions develop into typical elongated, necrotic lesions characteristic of a susceptible response (Carson, 1995). Lesion expansion is a major component of many polycyclic epidemics as in Exserohilum turcicum (Pass.) K.J. Leonard \& E.G. Suggs on maize (Berger et al., 1997). The chlorotic flecks that developed on cereal crops inoculated with $D$. gigantea, E. longirostratum, E. rostratum, or a mixture of these pathogens did not coalesce and expand, rather they disappeared over time. Also, there was extensive accumulation of dark pink to orange or brown colored substances in cells that were under attack from the pathogens. They appeared within $24 \mathrm{~h}$ after inoculation in and around the cells under attack, and pathogen growth was restricted to initial site of penetration.

In susceptible and resistant corn leaves infected with Bipolaris maydis, higher levels of accumulation of proteins and phenolic compounds occurred in the resistant variety as compared to the susceptible variety (Angra-Sharma \& Sharma, 1994). These compounds may restrict the infection from progressing any further. Plants resist pathogen attack in many 
ways as mentioned. Among these is the production of phytoalexins that kill the pathogen or restrict its intracellular development. Phytoalexins are low molecular weight, lipophilic, antimicrobial compounds that accumulate rapidly around sites of incompatible pathogen infections. The time, place, and amount of phytoalexin synthesis in any plant is critical to timing of biochemical events necessary for recognition of the pathogen and the expression of resistance (Snyder \& Nicholson, 1990). Juvenile plants of both resistant and susceptible cultivars synthesize phytoalexins and resist the fungus. As susceptible cultivars mature, they lose the ability to respond rapidly to fungal infection (Nicholson et al., 1986; 1988).

In sorghum, phytoalexins are synthesized in inclusions within the cell under attack. The inclusions move to the site of attempted penetration into the cell, and release phytoalexins into the cytoplasm. This is followed by additional phytoalexin synthesis occurring in surrounding cells (Snyder \& Nicholson, 1990). Sorghum phytoalexins, deoxyanthocyanidins, are visible pigments that differ in color from other cell components of the plant (Nicholson et al., 1986). The inclusions are initially colorless and within $24 \mathrm{~h}$ turn orange-red, a color that corresponds to the visible spectrum of the isolated phytoalexins (Nicholson et al., 1986; 1988). The inclusions become more intensely pigmented with time. The pigments are progressively synthesized in cells immediately surrounding the original infection site. These studies further indicate the relationship between accumulation of specific phytoalexins and resistance to fungal pathogens. In this study, in cereal crops inoculated with a mixture of $D$. gigantea, E. longirostratum, and E. rostratum, there was extensive accumulation of lipophylic, dark pink to orange or brown colored compounds in and around sites of pathogen ingress. 
In 1988, Figliola conducted host-range tests with Bipolaris setariae (Sawada) Shoemaker and Pyricularia grisea (Cooke) Sacc., pathogens of goosegrass. Representative plants of the Fabaceae, Malvaceae, Poaceae, and Solanaceae were tested. Infection was limited to members of the Poaceae. Sorghum showed a hypersensitive resistance response to B. setariae. Both cultivars of corn tested developed light symptoms upon inoculation with both fungi. Zhang and Watson (1997c) screened 56 plant species in 43 genera and 19 families against Exserohilum monoceras (Drechs.) K.J. Leonard \& E.G. Suggs, a pathogen of Echinocola spp. Among the crops tested, only corn seedlings were slightly infected. Sorghum and sugarcane were hypersensitive to the pathogen. In this study, the crop species were challenged with an emulsion-based inoculum of the pathogen mixture. All tested crop species were immune to the emulsion-based inoculum preparation of the pathogen mixture (Table 4-2). Furthermore, these bioherbicidal pathogens will be used to control weedy grasses mainly in tree crops, such as citrus, and these fungi are not reported in the literature as pathogens of citrus. The host-range tests further confirmed that these fungi do not infect orange (Hamlin) and grapefruit (white) cultivars tested. Thus, it appears safe to use $D$. gigantea, E. longirostratum, and E. rostratum, either alone or as a mixture, to control weedy grasses in citrus orchards. 


\section{CHAPTER V \\ A TECHNIQUE FOR MASS PRODUCTION AND MULTIPLE HARVESTING OF BIOHERBICIDAL FUNGI BY BIPHASIC CULTURING}

\section{Introduction}

Any technique used for mass production of inoculum should be cost-effective and yield high concentrations of viable, highly efficacious, and stable propagules amenable to long-term storage. Usually, propagules (inoculum) of fungal bioherbicides are asexual spores, such as conidia, chlamydospores, and others. Mycelial fragments of fungi can also be used, but generally they are less infective, less viable, and less durable in storage compared to spores (Boyette et al., 1991a). DeVine ${ }^{\circledR}$, a bioherbicide used in citrus in Florida to control milkweed vine consists of chlamydospores in a liquid formulation (Kenney, 1986).

Four methods of mass production of bioherbicides are common: i) liquid fermentation (submerged culture), ii) solid-substrate culture, using agar media and various natural materials such as agricultural waste products, iii) biphasic culturing, and iv) in vivo production on live host plants (e.g., mass production of propagules of rust and smut pathogens) (Jackson et al., 1996). Liquid fermentation is widely used, and is preferred for two major reasons: first, extensive information is available on optimizing the production process, and second, the production process can be controlled to provide specific cultural conditions ( $\mathrm{pH}$, temperature, aeration, agitation, etc.). 
Conidia are difficult to produce in liquid or submerged fermentation (Papavizas et al., 1984; Harman et al., 1991). Many fungi do not sporulate under submerged conditions. Some do sporulate in liquid culture, but recovery of spores from submerged cultures can be a problem, requiring extensive filtration or centrifugation to concentrate the spores. Filtration methods often leave a large number of spores behind in the mycelial mass. After the spores are recovered, it is usually necessary to dry them for long-term storage, and the drying process could affect spore viability.

Submerged fermentation has been used for commercial production of the bioherbicides, Collego ${ }^{\circledast}$ and DeVine ${ }^{\circledast}$ (Stowell, 1991). Colletotrichum gloeosporioides f. sp. aeschynomene (COLLEGO) is well adapted to submerged fermentation conditions in which spores are produced, most of which are different from the conidia that form on the weed host. Despite this difference, the majority of spores grown in submerged fermentation were pathogenic to the weed host (Churchill, 1982).

Roller drums and tray cultures have been used for the mass production of some fungi that do not produce spores in submerged liquid fermentations. Production of spores on solid media may be relatively costly in terms of labor and materials. It may, however be feasible in countries where labor is relatively inexpensive and suitable raw material needed to produce spores is cheap and easily available (Auld, 1997). Some difficulties of the solidsubstrate culture system include the problems of maintenance of sterility during culturing and control over cultural conditions. Also, the spores produced may be difficult to separate from the substrate. This adds to the volume of the end product, increasing the costs of its storage and transportation (Hasseltine, 1977; Jackson et al., 1996). In a two-phase system, mycelium is produced in deep-tank fermentation and then it is spread and the fungus allowed to 
sporulate on a solid surface in shallow open trays. Walker and Riley (1982) used a twophase system to produce spores of Alternaria cassiae Jurair \& Khan, a biocontrol agent for sicklepod, Senna obtusifloia (L.) Irwin \& Barneby.

A biphasic culturing system has been used to produce spores for several fungi. Spores of Pyricularia oryzae Cav. have been produced from the mycelium grown in liquid culture (Latterell, 1975), and then the mycelium separated from the liquid, placed on a wire screen, and incubated under continuous light for $2-3$ days at $26^{\circ} \mathrm{C}$ and $97-98 \% \mathrm{RH}$. The spores were harvested in an organic solvent, dried, passed through a screen, packaged, and stored at $4^{\circ} \mathrm{C}$. This procedure was modified by Walker (1980) to produce spores of Alternaria macrospora Zimm. for field studies to control spurred anoda (Anoda cristata (L.) Schlecht.). In Walker's method, the fungal mycelium was first produced in liquid culture. Then the mycelium was blended, antibiotics were added, and the mycelial homogenate poured into an aluminum-foil-lined plastic pan. The pans containing the mycelial homogenate were incubated at ambient laboratory temperature, exposed initially to $7 \mathrm{~h}$ of light, followed by $13 \mathrm{~h}$ of darkness, and again followed by $4 \mathrm{~h}$ of light. Alternating light was necessary for spore production. Conidia formed within $24 \mathrm{~h}$. They were air dried further for $24 \mathrm{~h}$ in the dark. Spores were collected with cyclone spore collectors that were connected in series to a vacuum pump with adjustable suction.

Churchill (1982) reviewed the key steps in a fermentation program to mass produce fungal inoculum. Important first step in the fermentation program is the proper maintenance of stock cultures. The stock cultures may be soil cultures, lyophilized cultures, agar slants, or spore suspensions. It is preferable to store the stock cultures in several ways to avoid the loss of valuable cultures during storage. The derivation of a stock culture from a single spore 
minimizes morphological variability and loss of virulence.

The most challenging aspect of mass production of propagules is the maintenance of sterility. The presence of contaminating bacteria is of primary concern in the production of bioherbicides since bacterial contaminants could affect the efficacy of inoculum. Avoidance of contamination in the primary, working inoculum and production cultures is important.

Bioherbicides have been produced by a variety of techniques (Stowell, 1991). Three of these techniques have been cited in use patents for bioherbicides. The first process was developed by Conway et al. (1978) for production of Cercospora rodmanii K. Conway and utilizes surface culture of mycelium in Roux bottles followed by homogenization of the mycelium. After harvest, the mycelium is formulated into either granules or a sprayable material. Methods to stabilize the mycelium were not described. However, this production strategy is simple and may be useful in early stages of product screening.

The second process utilizes submerged fermentation of mycelium followed by harvest and treatment of the mycelium to induce sporulation. This process was developed to circumvent the problems encountered in fermentation of fungi that do not readily sporulate in liquid culture (Walker, 1983) and is similar to spore production techniques for use in bioconversion of organic molecules (Vezina et al., 1965). After submerged fermentation, the whole broth is homogenized and either poured directly into trays or mixed with granules that immobilize the mycelium and provide a larger surface area for sporulation. In both cases, the environment must be modified to induce sporulation by providing light or $\mathrm{CO}_{2}$ (Cotty, 1987; Walker, 1983). Spores of Alternaria cassiae Jurair \& Khan produced by these methods could be harvested by vacuum or the granular product could be applied directly to the field. The granular process has also been used to produce a Fusarium-based bioherbicide 
(Walker, 1983).

The third production scheme takes advantage of standard fermentation and downstream processing equipment. This technique has been used for the production of several Colletotrichum-based bioherbicides. After submerged fermentation, the spores are separated from the mycelium by filtration and concentrated by centrifugation. Freeze- drying was used to stabilize spores. In a commercial production system, a more common drying process (drum, spray, or fluid-bed dryers) would probably replace freeze drying. All of these processes are valuable to produce inoculum for early evaluation of potential bioherbicides in the greenhouse and the field. However, a more economical process is needed to bring bioherbicides to the commercial market place.

Some of the fungi in the genus Drechslera are not known to sporulate in liquid culture (Stowell, 1991). Drechslera gigantea (Heald \& Wolf) Ito, Exserohilum longirostratum (Subram.) Sivan., and Exserohilum rostratum (Drechsler) Leonard \& Suggs. did not sporulate readily in liquid culture. Hence, the objectives of this study were: i) develop a technique to mass produce spores of D. gigantea, E. longirostratum, and $E$. rostratum and ii) improve spore yields of these fungi.

\section{Materials and Methods}

Spores of the three potential fungal bioherbicides, D. gigantea, E. longirostratum, and E. rostratum, were produced using a biphasic system (Figure 5-1). Mycelial plugs (1-wk old, $0.5-\mathrm{cm} \mathrm{diam}$ ) were used to inoculate $100 \mathrm{ml}$ of $\mathrm{V} 8$ broth in $250 \mathrm{ml}$ flasks. The inoculated flasks were shake-cultured $(100 \mathrm{rpm})$ for $1-2$ days at $25^{\circ} \mathrm{C}$. The resulting starter culture was used to inoculate $1000 \mathrm{ml}$ of $\mathrm{V}-8$ broth in 2-L flasks $(50 \mathrm{ml}$ starter culture per 


\section{STOCK CULTURE}

$\downarrow$

Day 1 Inoculate $100 \mathrm{ml} \mathrm{V8}$ broth with $0.5 \mathrm{~cm}$ diameter mycelial plug.

(24-48 $\mathrm{h}$ incubation at $\left.25^{\circ} \mathrm{C}, 100 \mathrm{rpm}\right)$

$\downarrow$

\section{STARTER CULTURE}

!

Day 3 Transfer $50 \mathrm{ml}$ starter culture to $1 \mathrm{~L} \mathrm{~V} 8$ broth (i.e., $5 \%$ initial inoculum concentration).

(24-48 $\mathrm{h}$ incubation at $25^{\circ} \mathrm{C}, 100 \mathrm{rpm}$ )

PRODUCTION CULTURE

1

Day 5 Harvest mycelium and blend it after adding an antibiotic solution $(10 \mathrm{ml} / \mathrm{L})$. (Antibiotic solution contains streptomycin at $4 \mathrm{mg} / \mathrm{ml}$ and chloramphenicol at $2.5 \mathrm{mg} / \mathrm{ml}$ )

Pour mycelial homogenate onto a layer of V8 agar in trays (aluminum / plastic) lined with a single layer of aluminum foil $(500 \mathrm{ml}$ per tray, $37.5 \times 30 \times 1.25 \mathrm{~cm})$. $\downarrow$

Incubate trays under $12 \mathrm{~h}$ of light $\left(35 \pm 5 \mu \mathrm{E} / \mathrm{m}^{2} / \mathrm{s}\right)$ and $12 \mathrm{~h}$ of dark cycles on shelves fitted with fluorescent lights.

$\downarrow$

Day 6 1st spore collection ( within $24-48 \mathrm{~h}$ after incubation)

!

Day 7 2nd spore collection (after the next $24 \mathrm{~h}$ )

1

Day 83 rd spore collection (after the next $24 \mathrm{~h}$ )

Collect spores as many times as possible @ every 24 h period, until the agar dries out.

After every spore collection, allow the spores to settle, decant the supernatant, pool, and concentrate the spores.

Note: Spores can be stored at $2-4^{\circ} \mathrm{C}$, preferably with antibiotics (same as above). Starter cultures and production cultures can also be stored at $2-4^{\circ} \mathrm{C}$ for continuous production schedules.

Figure 5-1. Flow chart for production of conidia of Drechslera gigantea, Exserohilum longirostratum, and E. rostratum using a biphasic culturing system. 


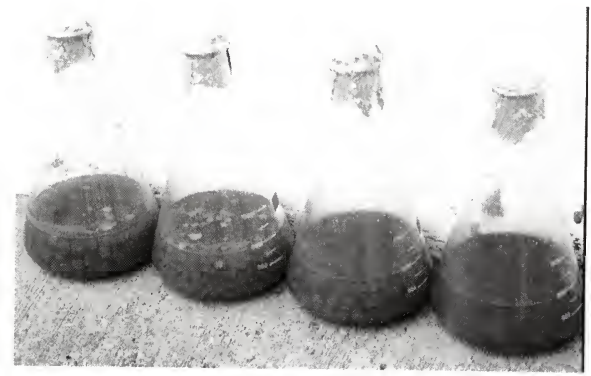

Step 1. Mycelial growth of fungi shake-cultured in V-8 broth (100 rpm, $25^{\circ} \mathrm{C}, 24-48 \mathrm{~h}$ ).

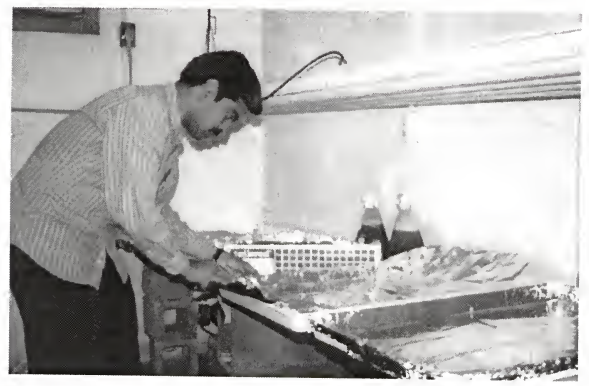

Step 2. Trays lined with aluminum foil.

Figure 5-2. A biphasic fungal spore-production technique. 


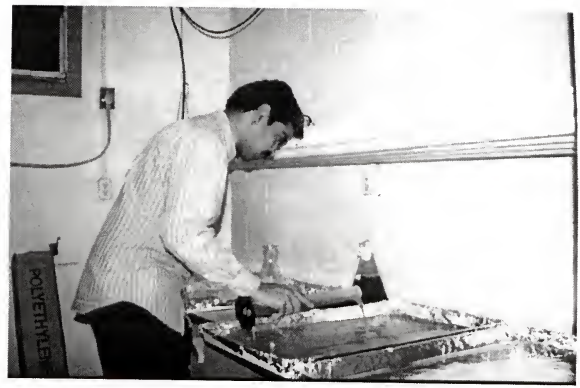

Step 3. V-8 agar is poured into trays and allowed to solidify.

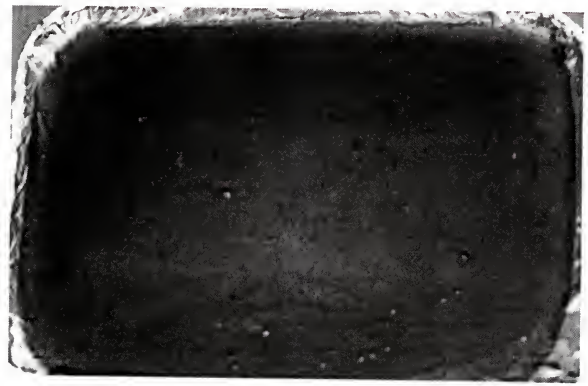

Step 4. Blended mycelial homogenate is poured over the layer of solidified V-8 agar. 


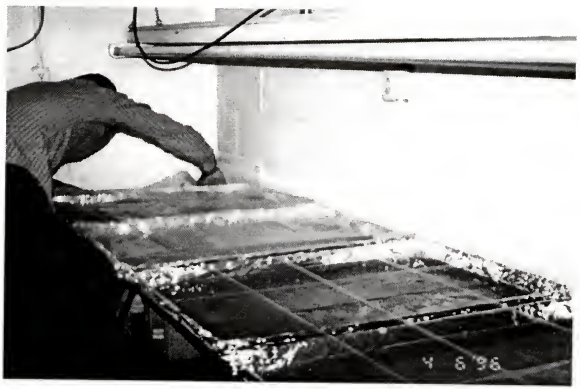

Step 5. The trays containing the mycelial homogenate are covered with clear polyethylene film.

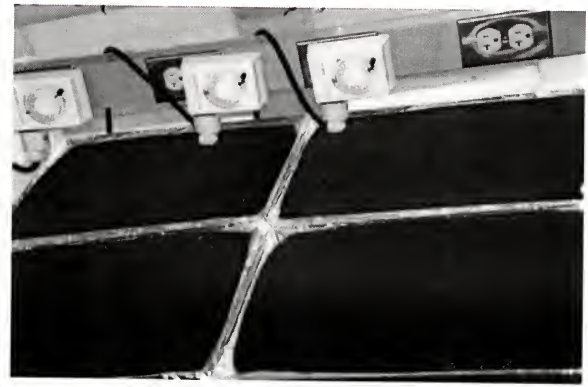

Step 6. Spores are formed on V-8 agar within $24-48$ h of incubation. 


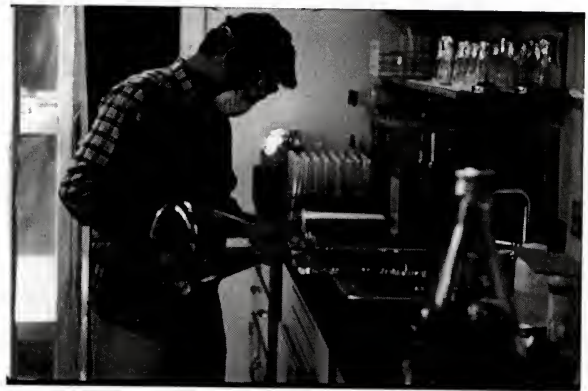

Step 7. Spores are collected in four steps: sterile water is poured on to the trays.

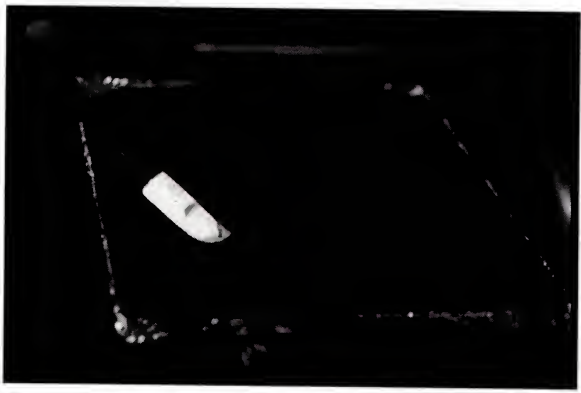

Step 8. Spores are gently scraped off the mycelial mat into sterile water. 


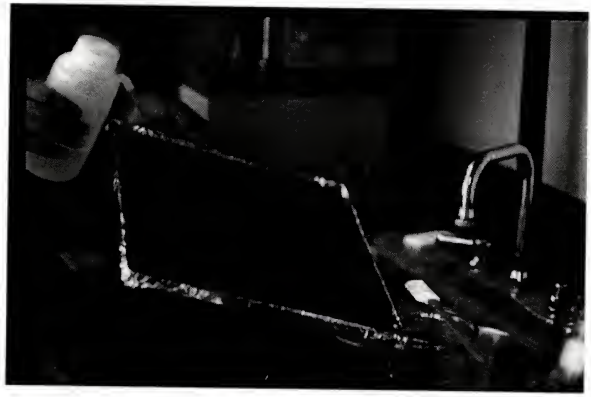

Step 9. Spores are washed off with a stream of sterile water.

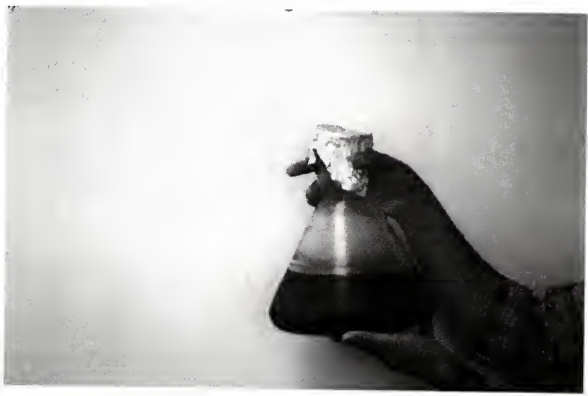

Step 10. Spores are allowed to settle and be concentrated. 
$1000 \mathrm{ml} \mathrm{V-8}$ broth), and shake-cultured as before to yield the production culture (Figure 5-2, step 1). The contents of each flask plus $10 \mathrm{ml}$ of an antibiotic solution $(3.7 \mathrm{mg} / \mathrm{ml}$ streptomycin and $2.5 \mathrm{mg} / \mathrm{ml}$ chloramphenicol) were blended in a Waring blender at low speed for 30-60 sec and $500 \mathrm{ml}$ of this suspension was poured onto a layer of V8 agar (500 $\mathrm{ml})$ containing antibiotics (as above) in trays $(37.5 \times 30 \times 1.25 \mathrm{~cm})$ lined with aluminum foil (Figure 5-2, steps 2 to 4). The trays were covered with clear polyethylene film (Figure 5-2, step 5) and exposed to alternating light and dark cycles ( $12 \mathrm{~h} / 12 \mathrm{~h}$ light $/ \mathrm{dark}, 35 \pm 5 \mu \mathrm{E} / \mathrm{m}^{2} / \mathrm{s}$ ) at room temperature. The initial crop of spores appeared within $24 \mathrm{~h}$ (Figure 5-2, step 6). These spores were collected in two steps (Figure 5-2, steps 7 to 10). First, the spores were gently scraped off with a rubber spatula into sterile water. The remaining spores were then rinsed off the agar surface with sterile water. The spore suspensions were pooled and the spores were allowed to settle. The excess supernatant was decanted and the spores were resuspended in $250 \mathrm{ml}$ of sterile water. The trays were reincubated under light as before and the spores were harvested twice more at $24 \mathrm{~h}$ intervals.

\section{Results}

The average spore yields per ml of V-8 agar in the tray were $2.59 \times 10^{5}, 5.47 \times 10^{5}$, and $1.89 \times 10^{5}$ for D. gigantea, E. longirostratum, and E. rostratum respectively (Table 5.1). In separate trials, three successive spore harvests could be obtained, and the spore yields per ml of V-8 agar for D. gigantea, E. longirostratum, and E. rostratum ranged from 0.95 to $1.72 \pm 0.43 \times 10^{5}, 0.13$ to $0.50 \pm 0.19 \times 10^{5}$, and 0.50 to $1.22 \pm 0.38 \times 10^{5}$ (Trial 1 ), and 0.54 to $1.74 \pm 0.60 \times 10^{5}, 0.22$ to $0.54 \pm 0.17 \times 10^{5}$, and 0.65 to $2.67 \pm 1.01 \times 10^{5}$ (Trial 2). 
Table 5-1. Spore yields ( $10^{5}$ per ml of V-8 agar) of Drechslera gigantea $(\mathrm{Dg})$, Exserohilum longirostratum $(\mathrm{El})$, and $E$. rostratum $(\mathrm{Er})$.

Tray No.

Fungal isolate

\begin{tabular}{llll}
\hline & Dg & El & Er \\
\hline 1 & 2.21 & 5.74 & \\
2 & 2.23 & 5.61 & 2.94 \\
3 & 2.51 & 7.11 & 1.66 \\
4 & 2.63 & 6.72 & 1.23 \\
5 & 2.64 & 4.44 & 2.15 \\
6 & 3.06 & 4.74 & 1.64 \\
7 & 2.82 & 3.90 & 1.94 \\
\hline Mean & & 1.67 \\
\hline Std Dev & 2.59 & 5.47 & 1.89 \\
\hline
\end{tabular}

Data represents spore yields per $\mathrm{ml}$ of V-8 agar. Spores from each tray (tray size $37.5 \times 30 \times 1.25 \mathrm{~cm} ; 500 \mathrm{ml}$ of V-8 agar per tray) were pooled into a total volume of $250 \mathrm{ml}$ and then counted. Each tray was considered as a replicate. 


\section{Discussion}

The objective of this study was to produce viable and infective inoculum by a rapid and inexpensive method. In the present study, fungal spores formed within 24 to $48 \mathrm{~h}$ after the blended mycelium was poured over V8 agar and incubated. This time period was not sufficient to dry the mycelium adequately to enable spore collection by vacuum as described by Walker (1980). However, if spores were not collected within $24 \mathrm{~h}$ after their formation, they germinated and produced extensive mycelial growth that led to a loss in spore yield. This necessitated the development of a new technique different from that of Walker's (1980). In this technique, blended mycelial homogenate was poured onto a layer of V8 agar contained in trays, rather than pouring homogenate directly into the trays as done by Walker (1980). The V8 agar supported the mycelial mat and the spores that formed could be gently scraped off into sterile water and collected. After the spores were collected, the same trays were reincubated and more crops of spores were obtained after every $24 \mathrm{~h}$. Thus, multiple harvests of spores (a minimum of three) were possible, and this increased the total spore yield per tray compared to a single harvest obtained using Walker's method (1980).

Chaurasia et al. (1998) were able to get four to six crops of spores of Alternaria triticina Prasada \& Prabhu, when the fungus was grown on wheat grains. In this method, the spores were collected from the colonized grains when the grains were shaken with water. The grains were again incubated at $25 \pm 2{ }^{\circ} \mathrm{C}$ and the spores were collected again. The fully colonized grains could be stored for 2 weeks at $25 \pm 2{ }^{\circ} \mathrm{C}$ and could be used for subsequent spore production. Yandoc and Charudattan (1998) were able to produce spores of $D$. gigantea on several grains, but $E$. longirostratum and E. rostratum do not sporulate readily on grains. Hence, a biphasic culturing system was developed, and it was feasible to produce 
masses of spores of D. gigantea, E. longirostratum, and E. rostratum, and to improve spore yields with multiple spore harvests. The spores were viable even after three years of storage as dry spores or in soil kept at $4^{\circ} \mathrm{C}$ (Appendix A). This system enabled the production of sufficient quantities of viable and infective spores that were used in the following field trials described in the next two chapters. 


\section{CHAPTER VI \\ FIELD EVALUATION OF A MULTIPLE-PATHOGEN STRATEGY FOR BIOHERBICIDAL CONTROL OF SEVERAL WEEDY GRASSES}

\section{Introduction}

Three fungi indigenous to Florida, Drechslera gigantea (Heald \& Wolf) Ito, Exserohilum longirostratum (Subram.) Sivan., and E. rostratum (Drechsler) Leonard \& Suggs., were isolated from large crabgrass, crowfootgrass, and johnsongrass and found to be capable of controlling the following weedy grasses: large crabgrass, crowfootgrass, johnsongrass, guineagrass, southern sandbur, Texas panicum, and yellow foxtail (Chapter III). Although these fungi were pathogenic to several weedy grasses, they were nonpathogenic to all of the dicotyledonous crop plants screened in a host-range trial. All graminaceous crop plants tested (corn, sorghum, wheat, rye, and oat) were resistant to infection by these pathogens. A mixture of these three pathogens was also nonpathogenic to the tested crop species. These fungi are considered safe biocontrol agents and further testing of these fungi to control weedy grasses under field conditions was undertaken.

Disease development under field conditions is often restricted to a large extent by low humidity and short duration of dew. Many fungi require high humidity conditions for germination and sporulation on their hosts. Colletotrichum orbiculare (Berk. \& Mont.) von Arx, a pathogen of bathurst burr (Xanthium spinosum L.) required an optimum dew period of $48 \mathrm{~h}$ and temperatures between $20-25^{\circ} \mathrm{C}$ for maximum infection (McRae \& Auld, 1988). 
Disease severity increased with longer duration of dew period. Colletotrichum gloeosporioides (Penz.) Sacc. f. sp. malvae, is a pathogen of round-leaved mallow (Malva pusilla $\mathrm{Sm}$.) and velvetleaf (Abutilon theophrasti Medic.). This pathogen required high humidity to infect the host, although further lesion development occurred under relatively dry conditions (Mortensen, 1988). Under controlled conditions, a minimum of $16-20 \mathrm{~h} \mathrm{dew}$ period at $20-25^{\circ} \mathrm{C}$ was required for maximum infection to occur.

Alternaria crassa (Sacc.) Rands, a pathogen ofjimsonweed (Datura stramonium L.) killed jimsonweed seedlings in the greenhouse over a broad range of environmental conditions (Boyette et al., 1991b). However, the weed control achieved under field conditions was substantially less than that obtained in the greenhouse. This could be due to a lack of adequate dew period or other unfavorable environmental conditions that restricted infection and disease development in the field. Multiple applications of this fungus may be required under conditions where large numbers of the weed emerge throughout the growing season.

Colletotrichum coccodes (Wallr.) Hughes is a potential bioherbicide for velvetleaf (Abutilon theophrasti Medic.). However, its efficacy under field conditions was often variable (Wymore \& Watson, 1989). The pathogen was favored by abundant moisture and moderate temperatures, conditions not always present in the field. If environmental conditions in the field are less than optimal for disease development, plants may continue to grow after shedding the diseased leaves. The reliability of field performance of this fungus could be increased significantly by improving inoculum formulation with additives (Wymore et al., 1987). 
Foliar-applied bioherbicides are sprayed in a similar manner to chemical herbicide application; hence, they will be affected in the same way as chemical herbicides. Spray of chemical herbicides is not completely intercepted by plant foliage (Gillespie \& Nalewaja, 1986), and the amount of spray reaching the weed surface is a function of plant canopy characteristics. Surface waxes of weeds greatly influence on the wettability and permeability of herbicides and other pesticides (Hull et al., 1982). Droplet size and herbicide concentration, the extent of spreading of spray droplets, and alterations in leaf cuticle by diluent-herbicide mixtures, all of these influence effectiveness of spray solutions that contain paraffinic oil (McWhorter \& Barrentine, 1988). Application of herbicides in paraffinic oil caused more rapid necrosis on seedling johnsongrass than the conventional method of application of herbicide in water plus oil concentrate. Paraffinic oil may aid the translocation of herbicide to the rhizomes of johnsongrass (Barrentine \& McWhorter, 1988).

The effect of carriers on the performance of bioherbicides has been studied. The simplest bioherbicide delivery system uses water as a carrier for the fungal propagules. However, foliage of most weeds are covered with a waxy cuticle that prevents water-based products from spreading evenly over weed surfaces. This can result in uneven distribution of the inoculum (fungal propagules). It is important that the surface area of a weed be covered with fungal propagules as evenly as possible. Surfactants help to reduce the surface tension of water droplets on plant surfaces and enhance wettability and even dispersal of fungal propagules. However, surfactants such as Tween-20 (POE sorbitan monolaurate) and Tween-80 (POE sorbitan monooleate) negatively affect spore germination, i.e., Alternaria cassiae Jurair \& Khan, a pathogen of sicklepod (Senna obtusifolia (L.) Irwin \& Barneby) (Walker \& Riley, 1982). 
A variety of oils and emulsifying agents have been screened to improve bioherbicide formulations (Womack \& Burge, 1993). Unrefined corn oil has been found to reduce the required minimum dew period, reduce spray volume rquired by 100 -fold from $500 \mathrm{~L} / \mathrm{ha}$ to $5 \mathrm{~L} /$ ha (Boyette, 1994). The corn oil also stimulated conidial germination and appressorial formation, resulting in increased infection by the pathogen (Egley \& Boyette, 1995). Invert emulsions have been known to retard moisture evaporation and to trap water in the spray mix. This action reduces the length of dew period needed for spore germination and infection (Quimby et al., 1988 a,b; Daigle et al, 1990). In invert emulsions (water-in-oil), the water phase is protected within a continuous oil phase. In several experiments conducted with a number of potential bioherbicides, invert emulsions promoted infection in the absence of available free moisture (Daigle et al., 1990; Boyette et al., 1993; Yang et al., 1993; Yang \& Schaad,1998).

When certain kinds of oils and emulsifying agents are used, specialized spraying equipment is needed to deliver the viscous formulation (Auld 1993; Boyette 1994, Womack \& Burge 1993; McWhorter et al., 1988). Vegetable oil-based emulsions are less viscous and can be applied with conventional spraying equipment (Auld, 1993). Connick et al. (1991b) developed an improved invert-emulsion formulation using an unsaturated monoglyceride (Myverol 18-99) as an emulsifier. This formulation has low viscosity and high waterretention capacity. Yang et al. (1993) developed similar invert emulsion formulations of Alternaria alternata (Fries) Keissler and A. angustiovoidea E. Simmons used to control Euphorbia esula L. (leafy spurge). This emulsion could be applied easily with a conventional sprayer. Conidia of both fungi, formulated in such an emulsion completely killed leafy spurge in the absence of dew in growth chambers, greenhouses, and field. In the 
study reported here, the emulsion-based inoculum was prepared as described by Yang et al. (1993), but Sunspray ${ }^{\circledR}$ E (a horticultural spray oil registered in Florida; SUNOCO, Philadelphia, PA) was used as the oil phase.

The objectives of this study were to i) evaluate the field-performance of $D$. gigantea, E. longirostratum, E. rostratum, and a mixture of these pathogens to control seven weedy grasses and ii) determine the effects of three carriers on the bioherbicidal efficacy of the pathogens under field conditions.

\section{Materials and Methods}

\section{Field Trial}

A field trial was performed during October to December 1996 at the Citrus Research and Education Center, Lake Alfred, FL. Seedlings of large crabgrass, crowfootgrass, johnsongrass, guineagrass, Texas panicum, southern sandbur, and yellow foxtail were raised in flats in a greenhouse from seeds purchased from Valley Seeds (Fresno, CA). The entire field area used for the study was cultivated before plots were laid out. Plots were $1 \mathrm{sq} . \mathrm{m}$ in size with 1 sq. $\mathrm{m}$ buffer area around each plot. When grass seedlings were 2-wk old, about 25 seedlings of each grass were transplanted randomly within each plot. The seedlings were allowed to become established for 2 weeks. When 4-wk old, the grasses were inoculated with spore suspensions of each pathogen alone or a mixture of the three pathogens $(1: 1: 1$ by vol). The experiment was a factorial RCB with isolate (individual pathogens and a mixture of all three pathogens) and carrier (water, $0.5 \% \mathrm{Metamucil}^{\otimes}$, and $40 \%$ emulsion) as factors. Four replicate plots were maintained for each treatment. Appropriate controls (carrier alone) were included. Weather data are provided in Appendix C. 
1998 Field Trial

A field trial was done at the Indian River Research and Education Center, Fort Pierce, FL in the same manner as in the 1996 trial, but during June to October 1998.

\section{Inoculum Production}

Spores of the three fungal pathogens to be tested, D. gigantea, E. longirostratum, and E. rostratum, were produced using the biphasic system. Mycelial plugs (1-wk old, $0.5 \mathrm{~cm}$ diam) were used to inoculate $100 \mathrm{ml}$ of V8 broth in $250 \mathrm{ml}$ flasks. The inoculated flasks were incubated on a shaker $(100 \mathrm{rpm})$ for $1-2$ days at $25^{\circ} \mathrm{C}$. The resulting starter culture was used to inoculate $1000 \mathrm{ml}$ of V-8 broth in 2-L flasks $(50 \mathrm{ml}$ starter culture per $1000 \mathrm{ml} \mathrm{V-8}$ broth), and cultured in shake-flasks as before to yield the production culture. The contents of each flask plus $10 \mathrm{ml}$ of an antibiotic solution $(3.7 \mathrm{mg} / \mathrm{ml} \mathrm{streptomycin} \mathrm{and} 2.5 \mathrm{mg} / \mathrm{ml}$ chloramphenicol) were blended in a Waring blender at low speed for 30-60 sec and $500 \mathrm{ml}$ of this suspension poured onto a layer of V8 agar $(500 \mathrm{ml})$ that contained antibiotics (as described above) in trays $(37.5 \times 30 \times 1.25 \mathrm{~cm})$ lined with aluminum foil. The trays were exposed to alternating light and dark cycles $\left(12 \mathrm{~h} / 12 \mathrm{~h}\right.$ light $/$ dark, $\left.35 \pm 5 \mu \mathrm{E} / \mathrm{m}^{2} / \mathrm{s}\right)$ at room temperature. The initial crop of spores appeared within $24 \mathrm{~h}$. These spores were collected in two steps: first, the spores were gently scraped off with a rubber spatula into sterile water; second, the remaining spores were then rinsed off the agar surface with sterile water. The spore suspensions were pooled and the spores were allowed to settle down. The excess supernatant was decanted and the spores were resuspended in $250 \mathrm{ml}$ sterile water. The trays were reincubated under light as before and the spores were harvested twice at $24 \mathrm{~h}$ and 48 h. The spore concentration was adjusted to $5 \times 10^{5}$ spores $/ \mathrm{ml}$ for each pathogen and a mixture 
of the three pathogens was prepared $\left(1: 1: 1 \mathrm{v} / \mathrm{v}\right.$; total spore concentration $5 \times 10^{5}$ spores $\left./ \mathrm{ml}\right)$. Spore suspensions from each tray typically contained about $5 \times 10^{5} \times 250 \mathrm{ml}$. Two liters of spore suspension containing $5 \times 10^{5}$ spores $/ \mathrm{ml}$ were required for spraying all treatments ( 48 sq. m. area). Either single spore harvest from 8 trays or two harvests at 24-h interval from 4 trays were sufficient to provide adequate inoculum for the field study.

\section{Field Testing}

Spore suspensions of each pathogen alone or a mixture of the three pathogens (1:1:1 by vol) were applied as foliar sprays $\left(5 \times 10^{5}\right.$ spores per $\left.\mathrm{ml}\right)$ with a $\mathrm{CO}_{2}$-propelled backpack sprayer in one of three carriers: water, $0.5 \%$ aqueous Metamucil ${ }^{\circledR}$ (Procter \& Gamble, Cincinnati, $\mathrm{OH}$ ), or an emulsion. The emulsion preparation contained $80 \mathrm{ml}$ Sunspray $6 \mathrm{E}$, $20 \mathrm{ml}$ paraffin oil, and $100 \mathrm{ml}$ spores in water ( $40 \%$ oil concentration). Appropriate controls were included. During the next $14 \mathrm{wk}$, two more applications of treatments were made at 2 and $5 \mathrm{wk}$ after initial spray (WAI) in 1996. In 1998, during a period of $14 \mathrm{wk}$, a second application of all treatments was done at 2 WAI. By $5 \mathrm{wk}$, guineagrass and johnsongrass had grown more than $5 \mathrm{~m}$ high and were unsprayable, and a third application of treatments as in 1996 was not done.

\section{Data Collection}

Disease was assessed as disease severity (DS) based on Horsfall-Barratt Scale (Horsfall \& Barratt, 1945). There are 12 classes in this scale which correspond to different levels of disease severity. The classes were: $0=0 ; 1=0-3 \% ; 2=3-6 \% ; 3=6-12 \% ; 4=12$ - 
$25 \% ; 5=25-50 \% ; 6=50-75 \% ; 7=75-88 \% ; 8=88-94 \% ; 9=94-97 \% ; 10=97-100 \%$ and $11=100 \%$. The mean class value was used to determine the final disease severity value. Disease rating was done at weekly intervals up to 6 weeks after initial spray (WAI) in 1996. In 1998, disease rating was done only up to $4 \mathrm{WAI}$. Data collection and data analysis were done in the same manner in 1996 and 1998.

\section{Data Analysis}

All percentage data were transformed by arcsine before analysis (Gomez \& Gomez, 1984). Analysis of variance (ANOVA) using the General Linear Model (GLM) was used (SAS Institute, Cary, NC) to analyze the effect of each factor individually and their interactions. The effects of fungal isolates and carriers were determined by analysis of variance of the transformed disease severity values. Data from the 1996 and 1998 field trials were analyzed separately.

\section{Results}

\section{Trial}

Inoculated weedy grasses developed foliar lesions, which turned necrotic by 1 week after initial spray (WAI). All the weedy grasses tested had maximum levels of disease severity in the emulsion-inoculum treatments. The severity in emulsion-inoculum treatments did not increase significantly during the period between application of treatments indicating lack of secondary cycles of inoculum production and disease development. The severity in emulsion-inoculum treatments increased significantly $(p=0.01)$ with each application of treatments. The maximum severities caused by inoculation with either the single pathogen 
or the pathogen mixture were not significantly different $(p=0.01)$ (Table 6.1). The severity for emulsion-based inoculum was significantly higher than for water-inoculum and Metamucil-inoculum treatments for all weed species (Figures 6.1-6.7).

\section{Trial}

The results obtained in 1998 trial were similar to that in the 1996 trial. Inoculated weedy grasses developed foliar lesions, which turned necrotic by 1 week after initial spray (WAI). All weedy grasses tested had high levels of disease severity in the emulsioninoculum treatments. The severity in emulsion-inoculum treatments increased significantly $(p=0.01)$ with each application of treatments. DS did not increase significantly during the period between application of treatments indicating lack of secondary cycles of inoculum production and disease development. The maximum severities caused by inoculation with either the single pathogen or the pathogen mixture were not significantly different $(p=0.01)$ (Table 6.2). The severity for emulsion-based inoculum was significantly higher than for water-inoculum and Metamucil-inoculum treatments for all weed species (Figures 6.8-6.14).

In 1996 and 1998, the weed control was effective for a period of more than 12 weeks (Figures 6.15-6.18), during which no regrowth of grasses occurred. In 1998, all the tested weedy grasses had high levels of disease in the emulsion-inoculum treatments. At 14 weeks after intial spray, the level of control in case of guineagrass and johnsongrass ranged from complete control to reduction in number of panicles (Appendix B). 
Table 6-1. Effect of inoculation with emulsion-based conidia of Drechslera gigantea (Dg), Exserohilum longirostratum (El), E. rostratum (Er), and a mixture of these pathogens on disease severity (\%) on selected weedy grasses at 6 weeks after inoculation (1996).

\begin{tabular}{lllll}
\hline Weed & \multicolumn{5}{c}{ Isolate $^{\mathrm{a}}$} \\
\hline & Dg & El & Er & $\begin{array}{l}\text { Mix } \\
(1: 1: 1 \mathrm{v} / \mathrm{v})\end{array}$ \\
\hline Guineagrass & $90.00 \mathrm{a}$ & $93.13 \mathrm{a}$ & $99.13 \mathrm{a}$ & $99.25 \mathrm{a}$ \\
Southern sandbur & $98.88 \mathrm{a}$ & $95.38 \mathrm{a}$ & $97.75 \mathrm{a}$ & $99.13 \mathrm{a}$ \\
Texas panicum & $95.13 \mathrm{a}$ & $100.00 \mathrm{a}$ & $87.13 \mathrm{a}$ & $96.63 \mathrm{a}$ \\
Yellow foxtail & $100.00 \mathrm{a}$ & $100.00 \mathrm{a}$ & $100.00 \mathrm{a}$ & $100.00 \mathrm{a}$ \\
Crowfootgrass & $97.38 \mathrm{a}$ & $98.25 \mathrm{a}$ & $95.0 \mathrm{a}$ & $98.75 \mathrm{a}$ \\
Johnsongrass & $97.88 \mathrm{a}$ & $90.00 \mathrm{a}$ & $95.13 \mathrm{a}$ & $97.00 \mathrm{a}$ \\
Large crabgrass & $78.13 \mathrm{a}$ & $91.38 \mathrm{a}$ & $79.13 \mathrm{a}$ & $74.25 \mathrm{a}$ \\
\hline
\end{tabular}

${ }^{a}$ Means with the same letters in the same row are not significantly different based on the least squares mean separation $(p=0.01)$. 

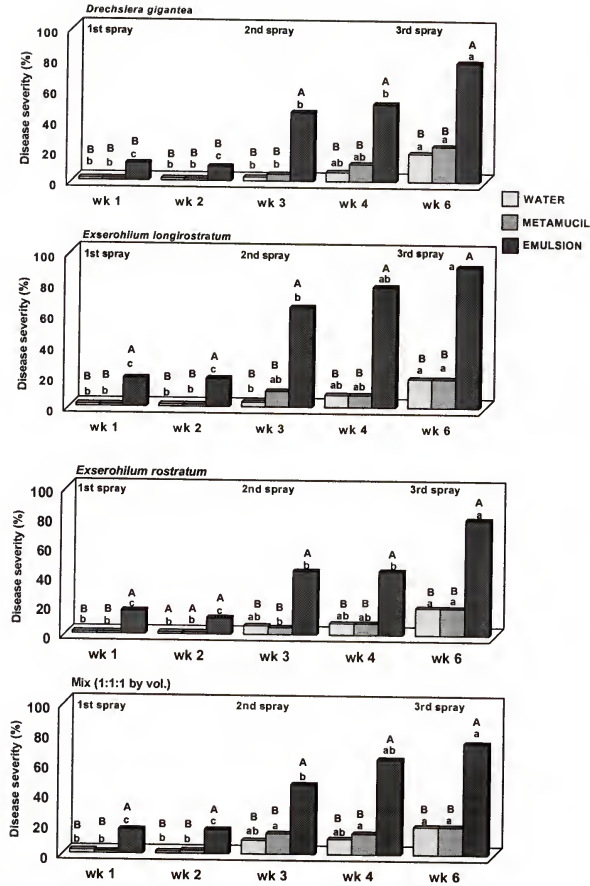

Figure 6-1. Effect of inoculation with Drechslera gigantea, Exserohilum longirostratum, Exserohilum rostratum, and a mixture of the three pathogens $(1: 1: 1 \mathrm{v} / \mathrm{v})$ on disease severity of large crabgrass (1996 trial). Disease severity (\%) values denoted by the same letter are not significantly different based on the least squares mean separation $(p=0.01)$. Lowercase letters represent effects of carriers over the weeks. Uppercase letters represent effects of carriers within each week. 

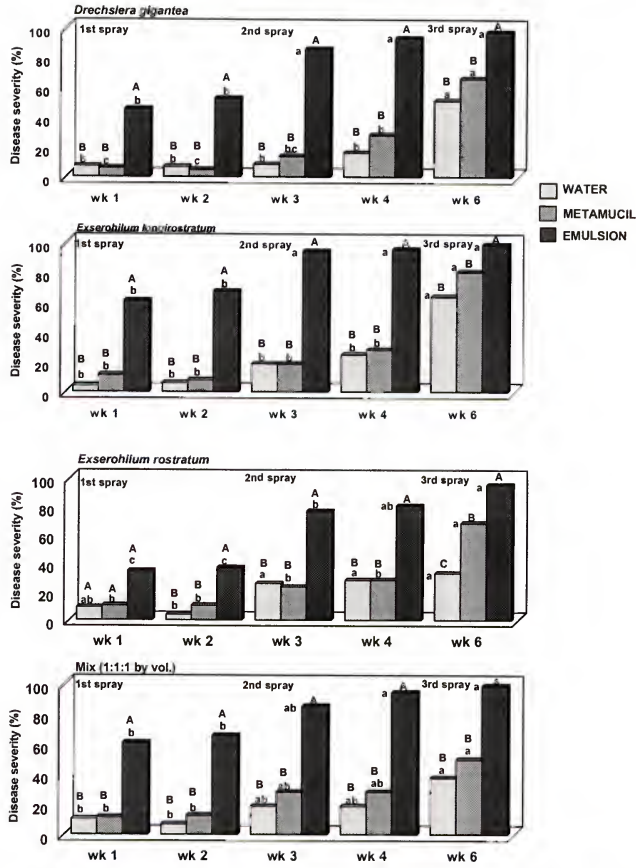

Figure 6-2. Effect of inoculation with Drechslera gigantea, Exserohilum longirostratum, Exserohilum rostratum, and a mixture of the three pathogens $(1: 1: 1 \mathrm{v} / \mathrm{v})$ on disease severity of crowfootgrass (1996 trial). Disease severity (\%) values denoted by the same letter are not significantly different based on the least squares mean separation $(p=0.01)$. Lowercase letters represent effects of carriers over the weeks. Uppercase letters represent effects of carriers within each week. 

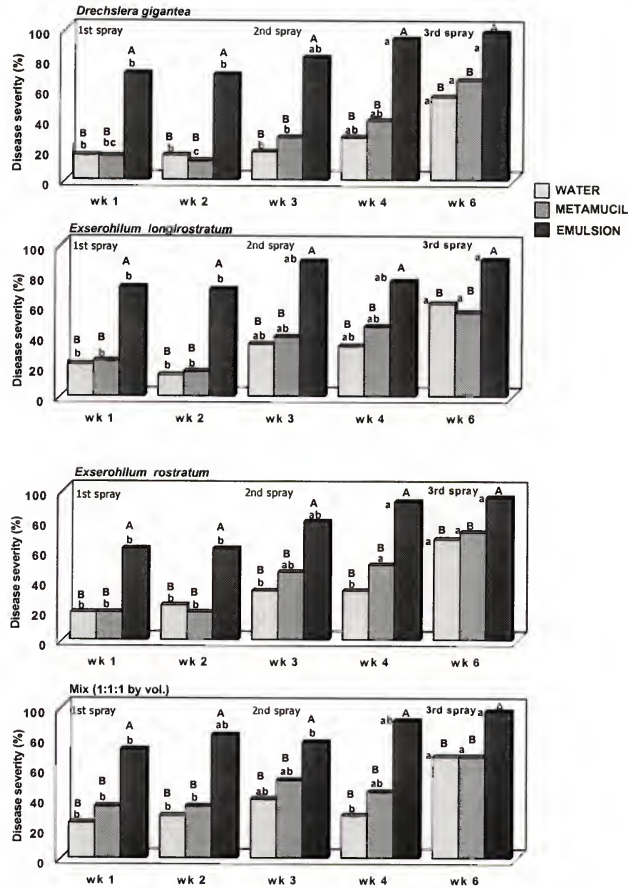

Figure 6-3. Effect of inoculation with Drechslera gigantea, Exserohilum longirostratum, Exserohilum rostratum, and a mixture of the three pathogens $(1: 1: 1 \mathrm{v} / \mathrm{v})$ on disease severity of johnsongrass (1996 trial). Disease severity (\%) values denoted by the same letter are not significantly different based on the least squares mean separation $(p=0.01)$. Lowercase letters represent effects of carriers over the weeks. Uppercase letters represent effects of carriers within each week. 

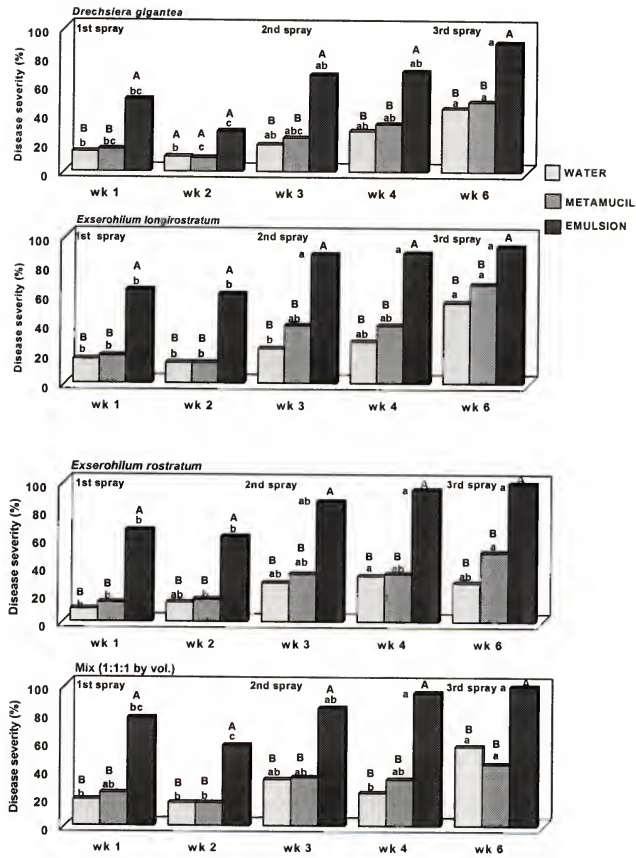

Figure 6-4. Effect of inoculation with Drechslera gigantea, Exserohilum longirostratum, Exserohilum rostratum, and mixture of the three pathogens $(1: 1: 1 \mathrm{v} / \mathrm{v})$ on disease severity of guineagrass (1996 trial). Disease severity (\%) values denoted by the same letter are not significantly different based on the least squares mean separation $(p=0.01)$. Lowercase letters represent effects of carriers over the weeks. Uppercase letters represent effects of carriers within each week. 

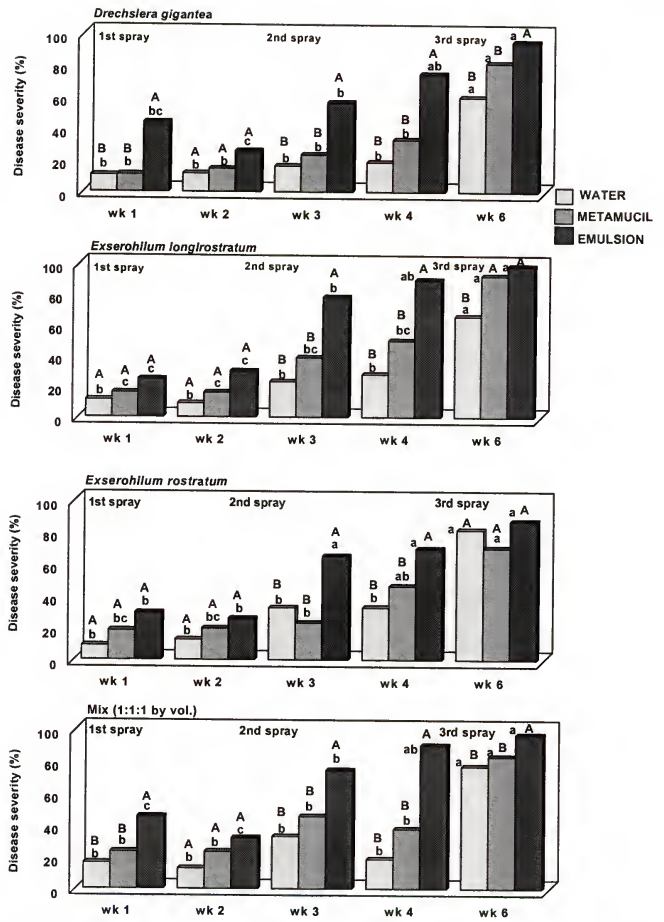

Figure 6-5. Effect of inoculation with Drechslera gigantea, Exserohilum longirostratum, Exserohilum rostratum, and a mixture of the three pathogens $(1: 1: 1 \mathrm{v} / \mathrm{v})$ on disease severity of Texas panicum (1996 trial). Disease severity (\%) values denoted by the same letter are not significantly different based on the least squares mean separation $(p=0.01)$. Lowercase letters represent effects of carriers over the weeks. Uppercase letters represent effects of carriers within each week. 

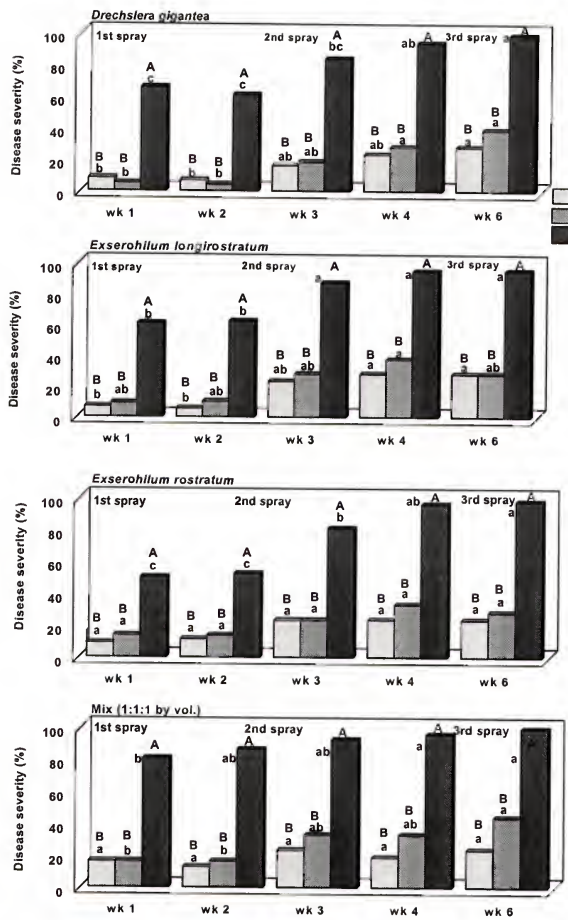

Figure 6-6. Effect of inoculation with Drechslera gigantea, Exserohilum longirostratum, Exserohilum rostratum, and a mixture of the three pathogens $(1: 1: 1 \mathrm{v} / \mathrm{v})$ on disease severity of southern sandbur (1996 trial). Disease severity (\%) values denoted by the same letter are not significantly different based on the least squares mean separation $(p=0.01)$. Lowercase letters represent effects of carriers over the weeks. Uppercase letters represent effects of carriers within each week. 

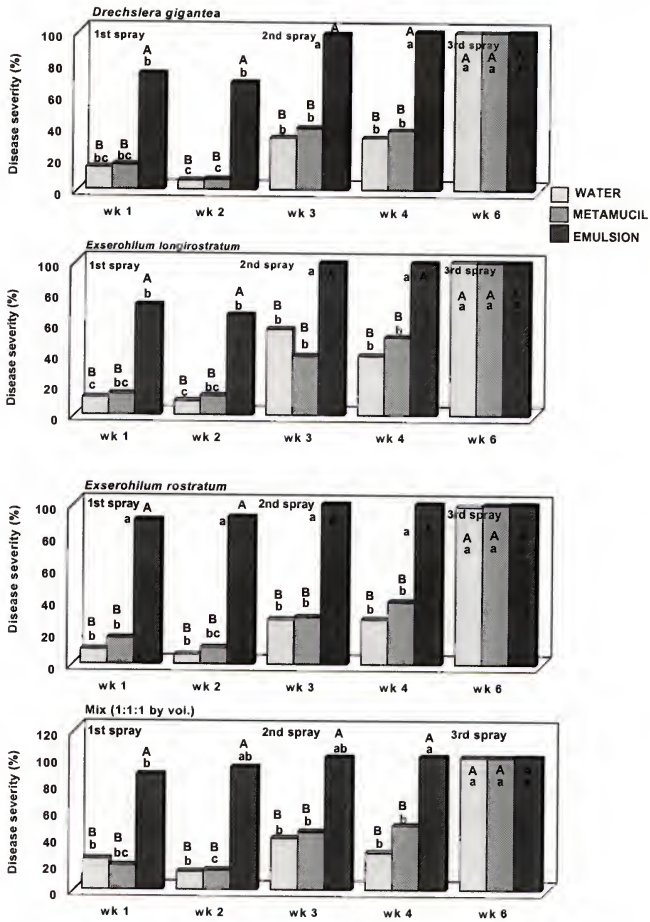

Figure 6-7. Effect of inoculation with Drechslera gigantea, Exserohilum longirostratum, Exserohilum rostratum, and a mixture of the three pathogens $(1: 1: 1 \mathrm{v} / \mathrm{v})$ on disease severity of yellow foxtail (1996 trial). Disease severity (\%) values denoted by the same letter are not significantly different based on the least squares mean separation $(p=0.01)$. Lowercase letters represent effects of carriers over the weeks. Uppercase letters represent effects of carriers within each week. 
Table 6-2. Effect of inoculation with emulsion-based conidia of Drechslera gigantea (Dg), Exserohilum longirostratum (El), E. rostratum (Er), and a mixture of these pathogens on disease severity (\%) of selected weedy grasses at 4 weeks after inoculation (1998).

\begin{tabular}{lllll}
\hline Weed & \multicolumn{5}{c}{ Isolate $^{\mathrm{a}}$} \\
\hline & Dg & El & Er & $\begin{array}{l}\text { Mix } \\
(1: 1: 1 \mathrm{v} / \mathrm{v})\end{array}$ \\
\hline Guineagrass & $71.88 \mathrm{a}$ & $80.38 \mathrm{a}$ & $72.00 \mathrm{a}$ & $76.63 \mathrm{a}$ \\
Southern sandbur & $98.50 \mathrm{a}$ & $98.50 \mathrm{a}$ & $98.50 \mathrm{a}$ & $98.50 \mathrm{a}$ \\
Texas panicum & $63.25 \mathrm{~b}$ & $59.50 \mathrm{~b}$ & $80.50 \mathrm{a}$ & $34.25 \mathrm{c}$ \\
Yellow foxtail & $98.50 \mathrm{a}$ & $98.50 \mathrm{a}$ & $98.50 \mathrm{a}$ & $98.50 \mathrm{a}$ \\
Crowfootgrass & $45.25 \mathrm{a}$ & $45.25 \mathrm{a}$ & $34.25 \mathrm{a}$ & $32.75 \mathrm{a}$ \\
Johnsongrass & $54.75 \mathrm{a}$ & $61.88 \mathrm{a}$ & $72.00 \mathrm{a}$ & $56.25 \mathrm{a}$ \\
Large crabgrass & $81.50 \mathrm{a}$ & $81.50 \mathrm{a}$ & $81.50 \mathrm{a}$ & $72.00 \mathrm{a}$ \\
\hline
\end{tabular}

${ }^{a}$ Means with the same letters in the same row are not significantly different based on the least squares mean separation $(p=0.01)$. 

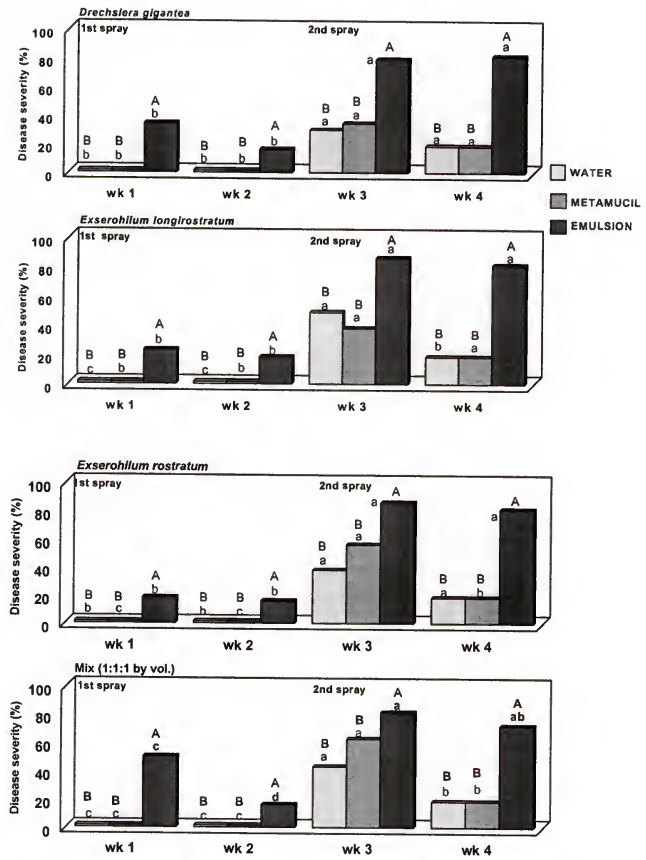

Figure 6-8. Effect of inoculation with Drechslera gigantea, Exserohilum longirostratum, Exserohilum rostratum, and a mixture of the three pathogens $(1: 1: 1 \mathrm{v} / \mathrm{v})$ on disease severity of large crabgrass (1998 trial). Disease severity (\%) values denoted by the same letter are not significantly different based on the least squares mean separation $(p=0.01)$. Lowercase letters represent effects of carriers over the weeks. Uppercase letters represent effects of carriers within each week. 

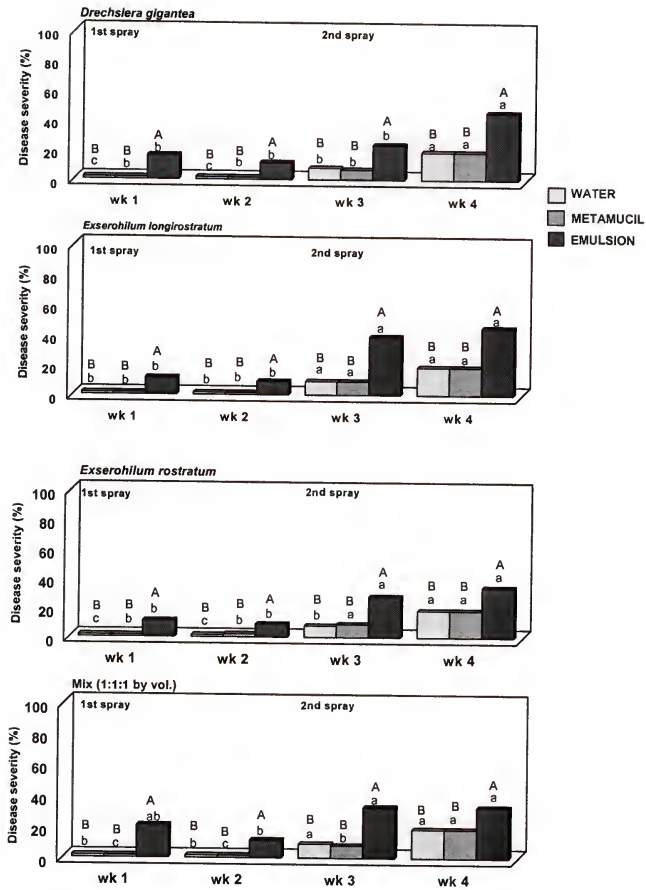

Figure 6-9. Effect of inoculation with Drechslera gigantea, Exserohilum longirostratum, Exserohilum rostratum, and a mixture of the three pathogens $(1: 1: 1 \mathrm{v} / \mathrm{v})$ on disease severity of crowfootgrass ( 1998 trial). Disease severity (\%) values denoted by the same letter are not significantly different based on the least squares mean separation $(p=0.01)$. Lowercase letters represent effects of carriers over the weeks. Uppercase letters represent effects of carriers within each week. 

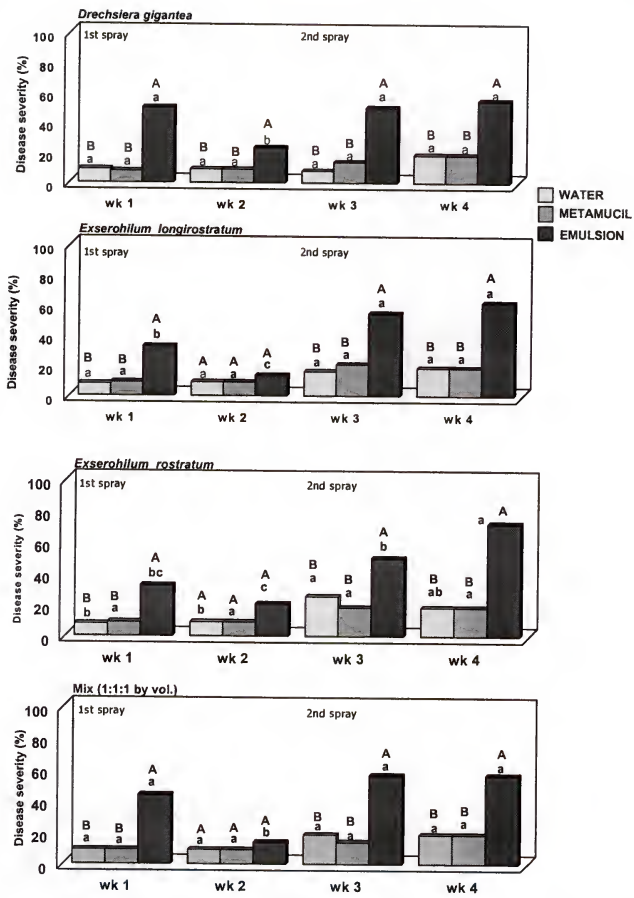

Figure 6-10. Effect of inoculation with Drechslera gigantea, Exserohilum longirostratum, Exserohilum rostratum, and a mixture of the three pathogens $(1: 1: 1 \mathrm{v} / \mathrm{v})$ on disease severity of johnsongrass (1998 trial). Disease severity (\%) values denoted by the same letter are not significantly different based on the least squares mean separation $(p=0.01)$. Lowercase letters represent effects of carriers over the weeks. Uppercase letters represent effects of carriers within each week. 

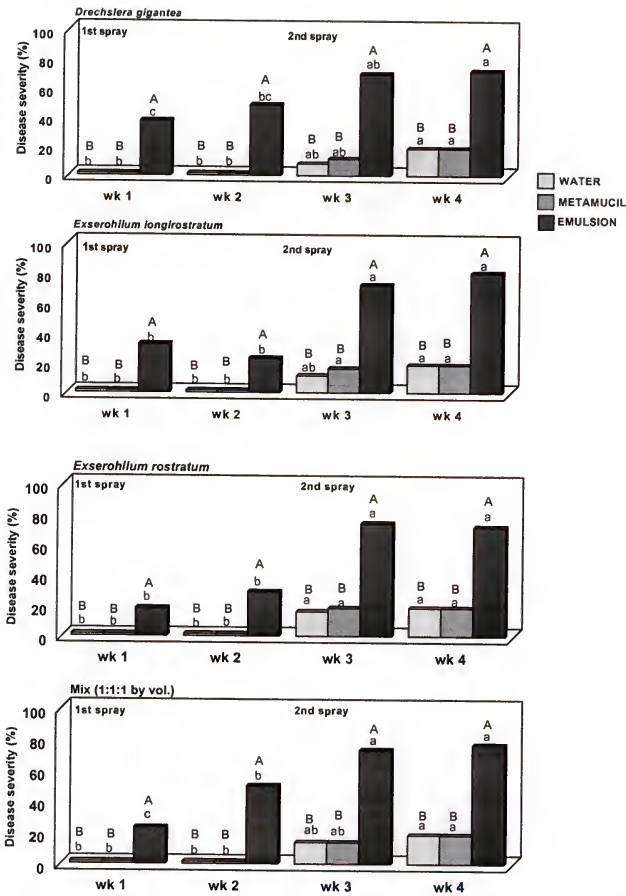

Figure 6-11. Effect of inoculation with Drechslera gigantea, Exserohilum longirostratum, Exserohilum rostratum, and a mixture of the three pathogens $(1: 1: 1 \mathrm{v} / \mathrm{v})$ on disease severity of guineagrass (1998 trial). Disease severity (\%) values denoted by the same letter are not significantly different based on the least squares mean separation $(p=0.01)$. Lowercase letters represent effects of carriers over the weeks. Uppercase letters represent effects of carriers within each week. 

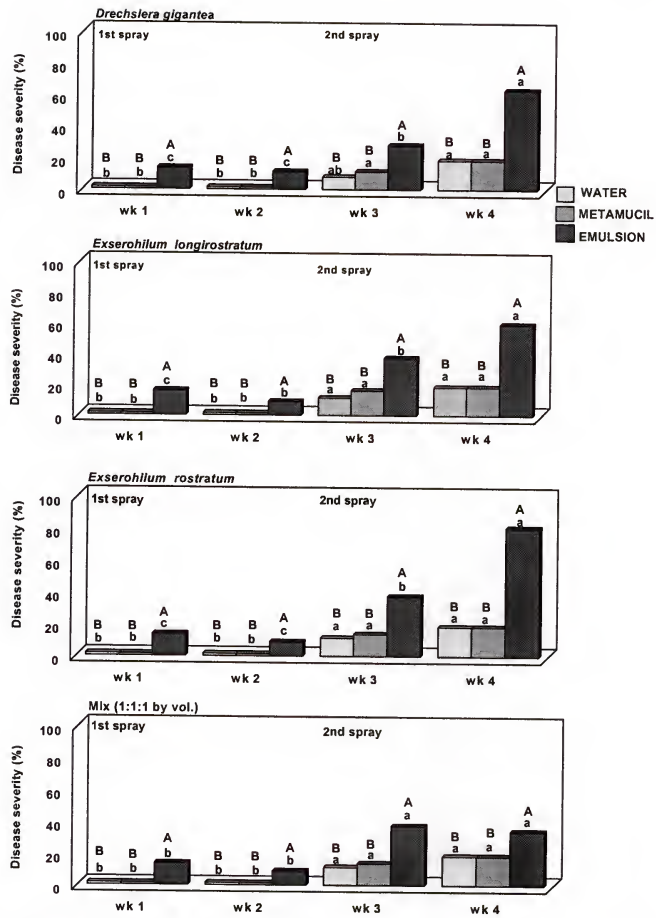

Figure 6-12. Effect of inoculation with Drechslera gigantea, Exserohilum longirostratum, Exserohilum rostratum, and a mixture of the three pathogens $(1: 1: 1 \mathrm{v} / \mathrm{v})$ on disease severity of Texas panicum (1998 trial). Disease severity (\%) values denoted by the same letter are not significantly different based on the least squares mean separation $(p=0.01)$. Lowercase letters represent effects of carriers over the weeks. Uppercase letters represent effects of carriers within each week. 

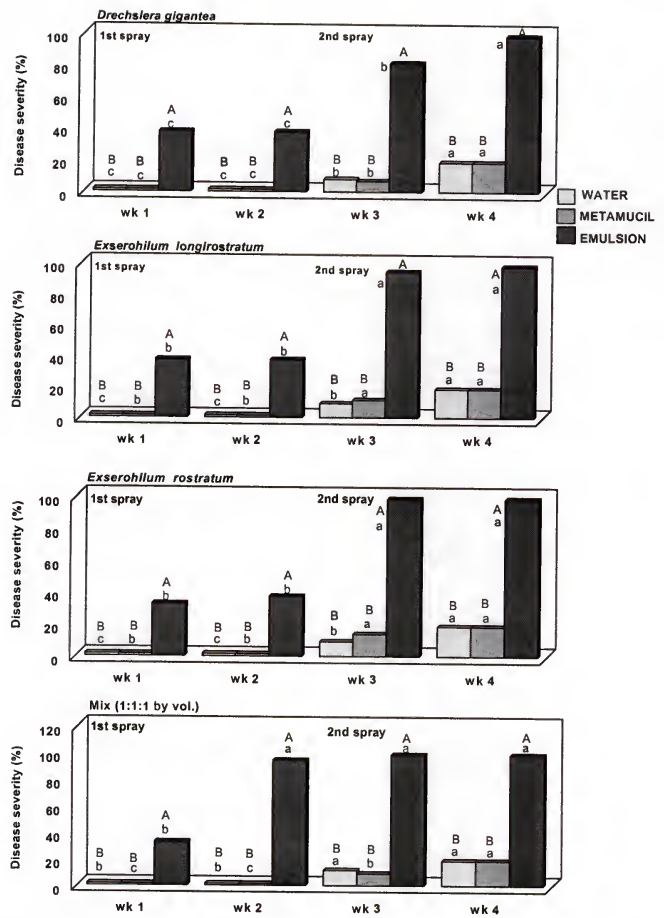

Figure 6-13. Effect of inoculation with Drechslera gigantea, Exserohilum longirostratum, Exserohilum rostratum, and a mixture of the three pathogens $(1: 1: 1 \mathrm{v} / \mathrm{v})$ on disease severity of southern sandbur (1998 trial). Disease severity (\%) values denoted by the same letter are not significantly different based on the least squares mean separation $(p=0.01)$. Lowercase letters represent effects of carriers over the weeks. Uppercase letters represent effects of carriers within each week. 

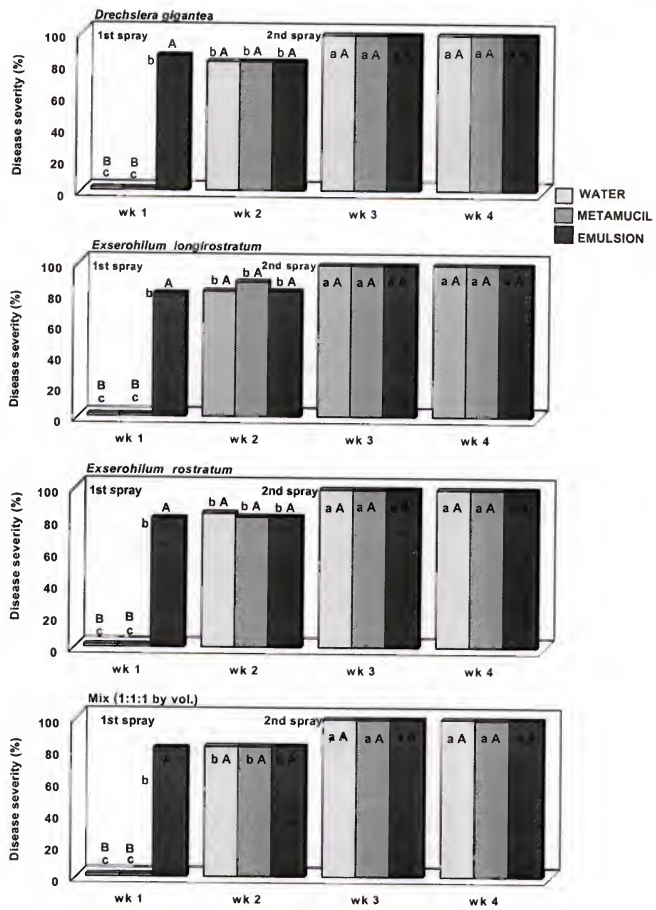

Figure 6-14. Effect of inoculation with Drechslera gigantea, Exserohilum longirostratum, Exserohilum rostratum, and a mixture of the three pathogens $(1: 1: 1 \mathrm{v} / \mathrm{v})$ on disease severity of yellow foxtail (1998 trial). Disease severity (\%) values denoted by the same letter are not significantly different based on the least squares mean separation $(p=0.01)$. Lowercase letters represent effects of carriers over the weeks. Uppercase letters represent effects of carriers within each week. 


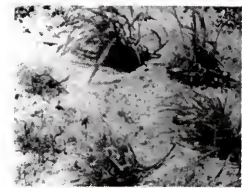

Drechslera gigantea

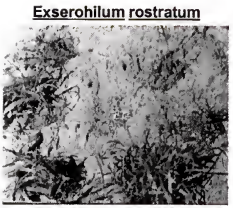

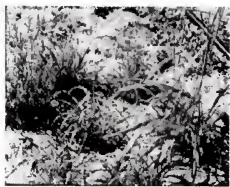

Noninoculated control (emulsion only)

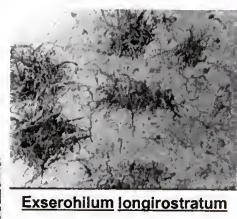

Mix (1:1:1 by vol.)

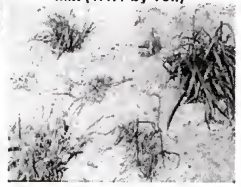

Figure 6-15. Effects of inoculation with Drechslera gigantea, Exserohilum longirostratum, E. rostratum, and a mixture of the three pathogens $(1: 1: 1 \mathrm{v} / \mathrm{v})$ on seven weedy grasses under field conditions at 2 weeks after initial spray. 


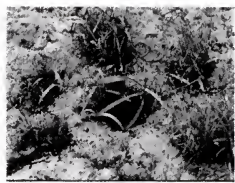

Drechslera gigantea

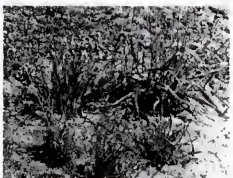

Noninoculated control (emulsion only)

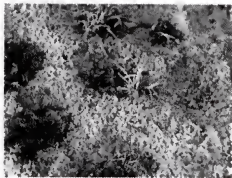

\section{Exserohilum longirostratum}

$\operatorname{Mix}(1: 1: 1$ by vol.)

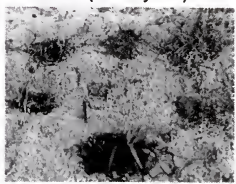

Figure 6-16. Effects of inoculation with Drechslera gigantea, Exserohilum longirostratum, E. rostratum, and a mixture of the three pathogens $(1: 1: 1 \mathrm{v} / \mathrm{v})$ on seven weedy grasses under field conditions at 4 weeks after initial spray. 


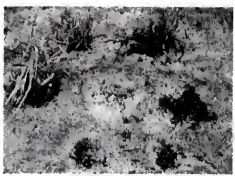

Drechslera gigantea

\section{Exserohilum rostratum}

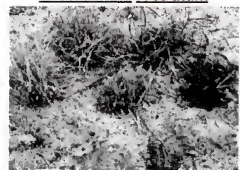

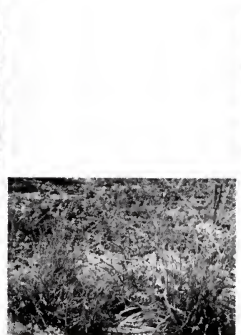

Noninoculated control (emulsion only)

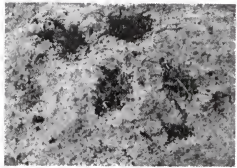

Exserohilum longirostratum

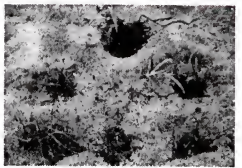

Figure 6-17. Effects of inoculation with Drechslera gigantea, Exserohilum longirostratum, E. rostratum, and a mixture of the three pathogens $(1: 1: 1 \mathrm{v} / \mathrm{v})$ on seven weedy grasses under field conditions at 7 weeks after initial spray. 


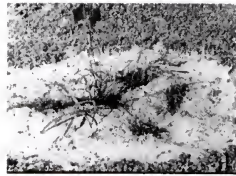

Drechslera gigantea
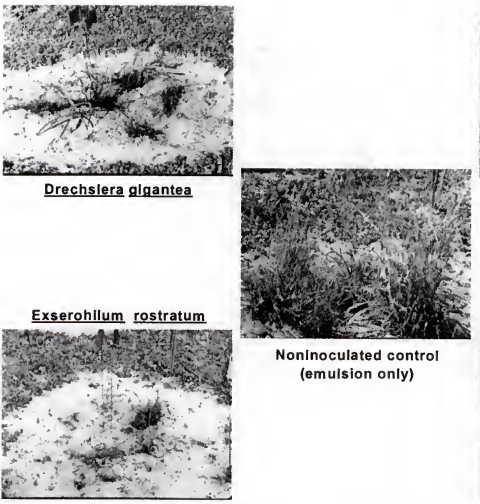

$$
\text { Noninoculated control }
$$$$
\text { (emulsion only) }
$$

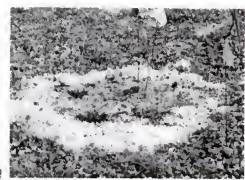

Exserohilum longirostratum

Mix (1:1:1 by vol.)

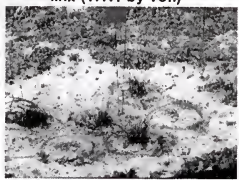

Figure 6-18. Effects of inoculation with Drechslera gigantea, Exserohilum longirostratum, E. rostratum, and a mixture of the three pathogens $(1: 1: 1 \mathrm{v} / \mathrm{v})$ on seven weedy grasses under field conditions at 14 weeks after initial spray. 


\section{Discussion}

The inoculated grasses developed foliar lesions characteristic of the diseases caused by $D$. gigantea, E. longirostratum, and E. rostratum within $24 \mathrm{~h}$ after inoculation. The leaves gradually turned necrotic over a period of one week. The level of necrosis depended on the uniformity of spore distribution on the foliage. Discrete lesions did not expand and the disease did not progress significantly during the period between two applications. This was interpreted as a lack of a significant secondary cycle of inoculum production by the pathogen.

In both 1996 and 1998, application of the emulsion-based inoculum resulted in maximum disease severity on all grasses at each week. Emulsion-based inoculum was more evenly spread on the grass leaf surface as compared to the water- and Metamucil-based inoculum. Disease severity in emulsion treatments increased significantly following the second application of treatments, but not after the third application. Two applications were sufficient to control all tested weedy grasses.

In 1998, the grasses grew much faster during the same time interval between sprays ( 2 weeks) and some reached 5-m tall, and could not be sprayed by 5 weeks after initial spray. Therefore, only two applications of treatments were made. Two sprays of individual pathogens and the pathogen mixture controlled all tested weedy grasses.

Although the maximum disease severity levels caused by inoculation with either individual pathogens or with the pathogen mixture were not significantly different in both 1996 and 1998 trials, it would be advantageous to use a mixture of the three pathogens to insure against possible failure of one or more agents in the mixture. The failure of one or two pathogens in the mixture may be compensated by the other. Also, by using the pathogen 
mixture, the possibility of development of resistance in the weed hosts to any one pathogen may be minimized.

A major constraint to the development of bioherbicides is the requirement for appropriate formulations for successful establishment of the bioherbicidal agent in the field (Auld, 1992; Baker \& Henis, 1990; Greaves \& Macqueen, 1990; Rhodes, 1990). Formulation of bioherbicides is the blending of the active ingredient, the biological propagule, with a carrier or solvent to produce a form which can be effectively delivered to the target weed (Boyette et al., 1991a; Rhodes, 1990). The type of formulation used for a bioherbicide depends on the type and mode of action of the pathogen, and available application technology. In the case of foliar-applied bioherbicides, the propagule remains on the leaf surface after application and is exposed to rain, abrasion, ultraviolet radiation, and desiccation, which may reduce its viability (Greaves \& Macqueen 1990; Rhodes 1990). Many bioherbicidal agents require a 6- to 24-h period of free water (dew period) for the propagule to germinate and penetrate the host (Auld, 1992; Auld \& Morin, 1995; Connick et al., 1990), and this is a very critical factor in biological weed control (Fernanado et al., 1994). Therefore, the timing of the application has to coincide with moist and humid environmental conditions. Such requirements may be overcome by formulations which protect the agent until host penetration is complete (Baker \& Henis, 1990; Rhodes, 1990; Winder, 1990; Winder \& Watson, 1990), and thus, increase the application window for the bioherbicide.

Liquid formulations include aqueous-, oil-, or polymer-based products, and are used as postemergence sprays to incite leaf and stem diseases on the weed host (Boyette et al., 1991a). The simplest bioherbicidal delivery system contains the propagules of the agent 
formulated as a sprayable suspension in water (Connick et al., 1990; Hofmeister \& Charudattan, 1987). This formulation is used mostly in the early stages of evaluation of a bioherbicidal pathogen while testing the efficacy of a potential biocontrol agent (Daigle \& Connick,1990). Recently, oil-in-water emulsions and invert emulsions (water-in-oil) have been used to enhance bioherbicidal efficacy (Auld, 1993; Boyette, 1994; Egley \& Boyette, 1995; Womack et al., 1996).

In most cases, bioherbicides are sprayed as conidial suspensions onto the weeds. However, evaporation of the water carrier is so rapid that sufficient time may not be available for spore germination and infection of the target weed to occur. An overspray of an invert-emulsion after treatment with an aqueous spray of spores can improve moisture retention, retard evaporation, insure germination of the fungus, and infection of the plant (Quimby et al., 1988 b). Thus, the use of low concentrations of vegetable oils with an emulsifying agent was found to enhance efficacy of Colletotrichum orbiculare to incite disease on spiny cocklebur (Xanthium occidentale, Bathurst burr) in the absence of dew in controlled experiments (Auld, 1993). However, these vegetable oil emulsions were not efficient in the field.

In invert-emulsion, the water droplets (dispersed phase) are surrounded by oil (continuous phase). This type of mixture reduces the surface area of water that is directly in contact with air and thus, reduces evaporation. Because of the viscosity of the emulsion, it can resist drift and it will be an advantage over aerial application of most water-based tank mixtures (Daigle et al., 1990). In our study, the emulsion enhanced the wettability of foliar surfaces of weedy grasses, and also facilitated an even distribution of the inoculum. The water or Metamucil-based inoculum beaded up on the leaf surface and was unevenly 
distributed. The emulsion-based inoculum yielded the best level of weed control, possibly due to better coverage of target weed surfaces, predisposal of weeds to the pathogens, and better diffusion of metabolites that may be produced by the pathogens. In the 1996 field trial, there was no phytotoxicity due to application of the emulsion alone. In 1998, the emulsion alone was phytotoxic to all grasses tested (av. 15-25\% of foliar injury on all grasses occurred after two applications, and the damage was significantly less compared to disease severity levels with pathogens in emulsion). However, the weeds recovered and continued to regrow. The phytotoxicity level was comparable to the level of senescence of weeds in control plots treated with water and Metamucil only. Also, the foliar injury from phytotoxicity was significantly less compared to emulsion-inoculum treatments.

In conclusion, all seven weedy grasses were almost completely killed in 1996 by an emulsion-based inoculum preparation of each pathogen as well as the mixture of the three pathogens. The weed control lasted for a period of more than 12 weeks, and no regrowth of grasses occurred with the exception of rhizome johnsongrass. In 1998, all the tested weedy grasses had high levels of disease in the emulsion-inoculum treatments. At 14 weeks after intial spray, the level of control in case of guineagrass and johnsongrass ranged from complete control to reduction in number of panicles. Reduction in panicle number is likely to result in reduced build up of seed bank over the years. The reduced level of grass control in 1998 is a result of aggressive weed growth during a comparable time interval as in 1996 and insufficient wettability of the foliage with the given volume of inoculum. The level of weed control might be improved by timing the second application based on the weed growth stage, when the weeds are at a sprayable height. 
In summary, D. gigantea, E. longirostratum, and E.rostratum have great potential to be used as bioherbicides to control the different weedy grasses tested: large crabgrass, crowfootgrass, johnsongrass, guineagrass, Texas panicum, southern sandbur, and yellow foxtail. Under field conditions, an emulsion-based inoculum provided the maximum level of weed control. Maximum level of weed control ( $90-100 \%$ kill) can be achieved with 2 to 3 applications of the bioherbicides, if applied during the early growth stage of the weeds. This weed control was effective for a period of more than 12 weeks. 


\section{CHAPTER VII \\ FIELD EVALUATION OF A PATHOGEN MIXTURE FOR BIOHERBICIDAL CONTROL OF GUINEAGRASS}

\section{Introduction}

Narrow-leaf guineagrass (NLG), also called narrow-leaf panicum or baby guineagrass (Panicum maximum Jacq.) (Figure 7-1) is a major weed problem in citrus in Florida (Akins, 1994). Narrow-leaf guineagrass has been spreading throughout the citrus-growing regions in Florida and adds significantly to the cost of weed management. It was first discovered on the east coast in the Indian River/Fort Pierce area in 1984. Since then, it has invaded the central and southern parts of the state. Its tolerance to chemical herbicides has warranted immediate, alternative control measures. The weed thrives in soils with high nutrient levels and is highly competitive with other plants and weeds, and successfully displaces even weeds such as torpedograss (Panicum repens L.), paragrass ( $P$. purpurascens Raddi), and bermudagrass (Cynodon dactylon (L.) Pers. (Akins, 1994). Narrow-leaf guineagrass is believed to have increased in numbers through long-term use of certain herbicides and cultural practices in Florida (Akins, 1994). The weed is a perennial and copious seed producer. It is easily spread by mowing and other mechanical operations within the citrus grove. It grows into clumps that can vine into citrus trees, which makes control operations difficult. 
Currently, Narrow-leaf guineagrass in citrus in Florida is managed by using a combination of chemical and mechanical control methods. Both preemergence and postemergence chemical herbicides are being used to control guineagrass (Futch, 1997; Futch et al., 1999). The preemergence herbicides are as follows: bromacil (5-bromo-6methyl-3-(1-methylpropyl)-2,4(1H,3H)pyrimidinedione), diuron (( $\left(\mathrm{N}^{\prime}-(3,4-d i c h l o r o p h e n y l)-\right.$ N,N-dimethylurea)), norflurazon (4-chloro-5-(methylamino)-2-(3-(trifluoromethyl)phenyl)$3(2 \mathrm{H})$-pyridazinone), oryzalin (4-(dipropylamino)-3,5-dinitrobenzenesulfonamide), oxyfluorfen (((2-chloro-1-(3-ethoxy-4-nitrophenoxy)-4-(trifluoromethyl))benzene), simazine (6-chloro-N,N'-diethyl-1,3,5-triazine-2,4-diamine), and thiazopyr (methyl 2(difluoromethyl)-5-(4,5-dihydro-2-thiazolyl)-4-(2-methylpropyl)-6-(trifluoromethyl)-3pyridinecarboxylate). The postemergence herbicides are as follows: sethoxydim ( $\{2-[1-$ (ethoxyimino) butyl]-5-[2-(ethylthio)propyl]-3-hydroxy-2-cyclohexen-1-one\}), fluazifop$\operatorname{butyl}(\{(\mathrm{R})-2-[4-[[5-($ trifluoromethyl)-2-pyridinyl]oxy] phenoxy]propanoic acid $\})$, paraquat (1,1'-dimethyl-4,4'-bipyridinium ion), and glyphosate ( $\mathrm{N}$-(phosphonomethyl)glycine). Glyphosate is an excellent general-purpose postemergence herbicide. Sethoxydim and fluazifop are selective postemergence herbicides, especially used to control perennial grasses such as bermudagrass, torpedograss, johnsongrass, and guineagrass (Retzinger \& Rogers, 1982; Winton \& Frans, 1984; Barrentine \& McWhorter, 1988).

Recommended herbicidal application rates (active ingredient/treated acre) to control weedy grasses are as follows (Tucker \& Singh, 1993; Futch, 1997; Futch et al., 1999): bromacil or diuron at 1.6-3.2 lb, norflurazon at $2.4-4.0 \mathrm{lb}$, oryzalin at $2.4 \mathrm{lb}$, oxyfluorfen at 0.5-2.0 lb, simazine at $2.25-3.96 \mathrm{lb}$, thiazopyr at $0.13-0.50 \mathrm{lb}$, sethoxydim at $0.38-0.47 \mathrm{lb}$, fluazifop-butyl at $0.25-0.38 \mathrm{lb}$, paraquat at $0.63-0.94 \mathrm{lb}$, and glyphosate at 1.0-4.0 lb. 
Narrow-leaf guineagrass is more difficult to control than the regular guineagrass biotype with these herbicides. The ineffectiveness of chemical herbicides is attributed to low level of translocation of herbicides from roots to shoots. Glyphosate is used to control established plants, followed by application of residual herbicides such as norflurazon to control any emerging seedlings. Mechanical mowing and treatment of row middles with chemical herbicides before seed-head emergence that coincides with application of residual herbicide are also practiced. For prolonged weed control, preemergence herbicides are applied repeatedly at lower rates in water rings or with microsprinklers. Weeds that escape mowing and preemergence herbicide treatment are controlled by spot treatments with postemergence herbicides such as glyphosate.

The objectives of this study were i) to determine the bioherbicidal efficacy of individual pathogens, $D$. gigantea, E. longirostratum, E. rostratum, and a mixture of these pathogens to control a natural population of guineagrass, and ii) to determine the effects of carriers (water, Metamucil ${ }^{\infty}$, and an invert emulsion) on bioherbicidal efficacy.

\section{Materials and Methods}

\section{Inoculum Production}

Spores of the three fungal pathogens to be tested, D. gigantea, E. longirostratum, and E. rostratum were produced using a biphasic system. Mycelial plugs (1-wk old, $0.5 \mathrm{~cm}$ diam) were used to inoculate $100 \mathrm{ml}$ of V8 broth in $250 \mathrm{ml}$ flasks. The inoculated flasks were incubated on a shaker $(100 \mathrm{rpm})$ for $1-2$ days at $25^{\circ} \mathrm{C}$. The resulting starter culture was used to inoculate $1000 \mathrm{ml}$ of V-8 broth in 2-L flasks $(50 \mathrm{ml}$ starter culture per $1000 \mathrm{ml} \mathrm{V-8}$ broth), and cultured in shake-flasks to yield the production culture. The contents of each 
flask plus $10 \mathrm{ml}$ of an antibiotic solution $(3.7 \mathrm{mg} / \mathrm{ml}$ streptomycin and $2.5 \mathrm{mg} / \mathrm{ml}$ chloramphenicol) were blended in a Waring blender at low speed for 30-60 sec and $500 \mathrm{ml}$ of this suspension poured onto a layer of V8 agar $(500 \mathrm{ml})$ that contained antibiotics (as above) in trays $(37.5 \times 30 \times 1.25 \mathrm{~cm})$ lined with aluminum foil. The trays were exposed to alternating light and dark cycles $\left(12 \mathrm{~h} / 12 \mathrm{~h}\right.$ light $/$ dark, $\left.35 \pm 5 \mu \mathrm{E} / \mathrm{m}^{2} / \mathrm{s}\right)$ at room temperature. The initial crop of spores appeared within $24 \mathrm{~h}$. These spores were collected in two steps: first, the spores were gently scraped-off with a rubber spatula into sterile water; second, the remaining spores were rinsed-off the agar surface with sterile water. The spore suspensions were pooled and the spores were allowed to settle down. The excess supernatant was decanted and the spores were resuspended in $250 \mathrm{ml}$ sterile water. The trays were reincubated under light as before and the spores were harvested twice at $24 \mathrm{~h}$ and $48 \mathrm{~h}$. The spore concentration was adjusted to $5 \times 10^{5}$ spores $/ \mathrm{ml}$ for each pathogen and a mixture of the three pathogens was prepared $\left(1: 1: 1 \mathrm{v} / \mathrm{v}\right.$; total spore concentration $5 \times 10^{5}$ spores $\left./ \mathrm{ml}\right)$. Spore suspensions from each tray typically contained about $5 \times 10^{5} \times 250 \mathrm{ml}$. Two liters of spore suspension containing $5 \times 10^{5}$ spores $/ \mathrm{ml}$ were required for spraying all treatments ( 48 sq. m. area). Either single spore harvest from 8 trays or two harvests at $24 \mathrm{~h}$ interval from 4 trays were sufficient to provide adequate inoculum for the field study.

\section{Field Trials}

A first field trial was first performed during September-December 1996 at the Indian River Research and Education Center, Fort Pierce, FL. A field area having dense and uniform growth of guineagrass was used for the study. The entire field area was mowed in the conventional way, and the mowed guinegrass plants were allowed to regrow for 1 week. 
Plots of 1 sq. $\mathrm{m}$ size were laid out within the field area with 1 sq. $\mathrm{m}$ spaces around each plot. The guineagrass plants within each plot were then inoculated with spore suspensions of each pathogen alone or a mixture of the three pathogens (1:1:1 by vol). The fungi were applied as foliar sprays with a $\mathrm{CO}_{2}$-propelled backpack sprayer, each at $5 \times 10^{5}$ spores per $\mathrm{ml}$. The inoculum suspensions were applied in one of three carriers: water, $0.5 \%$ aqueous Metamucil ${ }^{\circledast}$ (Procter \& Gamble, Cincinnati, OH) or an oil-based (Sunspray ${ }^{\circledR} 6 \mathrm{E}, \mathrm{SUNOCO}$, Philadelphia, PA) emulsion. The emulsion preparation contained $80 \mathrm{ml}$ Sunspray $6 \mathrm{E}, 20 \mathrm{ml}$ paraffin oil, and $100 \mathrm{ml}$ spores in water ( $40 \%$ oil concentration). Three controls consisting of the respective carriers only were included. During the experimental period of $10 \mathrm{wk}$, one additional spray of all treatments was done at 2 weeks after the initial spray. The experiment was a factorial RCB with isolate (individual pathogens, and a mixture of three pathogens) and carrier (water, Metamucil, and emulsion) as factors. Four replicate plots were maintained for each treatment. The field trial was repeated during April-July of 1998 at the same location in the same manner as in 1996, but in the Spring season. The weather data for both field trials is provided in Appendix C.

\section{Data Collection}

In both 1996 and 1998, disease was assessed for the entire group of plants within each plot as disease severity (DS) based on Horsfall-Barratt Scale (Horsfall \& Barratt, 1945) at weekly intervals for up to 6 weeks after initial spray. There are 12 classes in this scale which correspond to different levels of disease severity. The classes were: $0=0 ; 1=0-3 \%$; $2=3-6 \% ; 3=6-12 \% ; 4=12-25 \% ; 5=25-50 \% ; 6=50-75 \% ; 7=75-88 \% ; 8=88-94 \% ; 9=$ $94-97 \% ; 10=97-100 \%$ and $11=100 \%$. The mean class value was used to determine the 
final disease severity value.

\section{Data Analysis}

All percentage data were transformed by arcsine before analysis (Gomez \& Gomez, 1984). Analysis of variance (ANOVA) with the General Linear Model (GLM) procedure was used (SAS Institute, Cary, NC) to analyze the effect of each factor individually and their interactions. The effects of fungal isolates and carriers were determined by ANOVA of the transformed disease severity values. Data from the 1996 and 1998 field trials were analyzed as a split-plot design with 'year' as 'block', 'carrier and isolate combination' as 'whole-plot treatment', and 'week' as 'sub-plot' treatment. All 'year' and its interactions were all nonsignificant (isolate $\mathrm{x}$ year $p=0.1264$; carrier $\mathrm{x}$ year $p=0.8893$; isolate $\mathrm{x}$ carrier $\mathrm{x}$ year $p=$ 0.6253). Therefore, the disease severities from 1996 and 1998 were combined.

\section{Results}

Guineagrass plants sprayed with D. gigantea, E. longirostratum, E. rostratum, and a mixture of these pathogens developed foliar lesions and turned necrotic by 1 week after initial spray. The emulsion-based inoculum yielded better coverage of foliage with the inoculum, and maximum disease severity. The maximum severity in emulsion-inoculum treatments was significantly $(p=0.01)$ higher than that in water-inoculum and Metamucilinoculum treatments (Figure 7.1). Severity in emulsion-inoculum treatments increased significantly $(p=0.01)$ with the second application. There was no significant increase in severity during the period between two applications which meant that no secondary disease cycle occurred. There was also no disease spread beyond treated plots, which was additional evidence that no secondary inoculum production and dispersal occurred. The maximum 
disease severity caused by each of the pathogens and the pathogen mixture did not differ significantly $(p=0.01)$ (Table 7.1).

An emulsion-based inoculum preparation of the pathogens and a mixture of the three pathogens controlled guineagrass. The individual pathogens and the pathogen mixture were equally effective. The disease severity level increased significantly after each spray, and two sprays were sufficient to kill guineagrass almost completely (Figures 7.2-7.4). The weed control lasted for 10 weeks without any regrowth of the weed.

\section{Discussion}

Citrus is the most important crop in Florida grown in over 850,000 acres and with a tree value of $\$ 1.1$ billion as of 1996 . The economic value of citrus to the state's economy is about $\$ 8$ billion, with 144,000 people employed in the industry. Management of weeds costs the Florida citrus industry about $\$ 200$ per acre per year of a Valencia grove producing fruit for the processed market in Central Florida. The cost of weed control as a percentage of the total specified production cost has increased from about $10 \%$ in $1976-77$ to almost $25 \%$ in $1995-96$. If no herbicides were used, losses due to weeds to the Florida citrus industry might reach an estimated $\$ 750$ million per year. Such losses are a consequence of the cost of weed control operations, direct competitive effects, and the reduced efficiency of production and harvesting operations.

Mowing and chemical control are the widely used methods of weed control in Florida citrus. Control of perennial weeds like guineagrass in citrus groves is rarely achieved by cultivation, and infrequent cultivation results in the establishment of stands of aggressive weed species. In addition, cultivation damages the surface feeder roots of citrus, and 
Table 7-1. Effect of inoculation with emulsion-based conidia of Drechslera gigantea, Exserohilum longirostratum, E. rostratum, and a mixture of these pathogens on disease severity (\%) of narrow-leaf guineagrass at 4 weeks after inoculation.

\begin{tabular}{llll}
\hline Isolate $^{\mathrm{a}}$ & \multicolumn{3}{c}{ Carrier } \\
\hline & Water & Metamucil & Emulsion \\
\hline Drechslera gigantea & $10.00 \mathrm{a}$ & $16.44 \mathrm{a}$ & $97.06 \mathrm{a}$ \\
Exserohilum longirostratum & $8.13 \mathrm{a}$ & $16.81 \mathrm{a}$ & $95.88 \mathrm{a}$ \\
E. rostratum & $11.13 \mathrm{a}$ & $20.31 \mathrm{a}$ & $97.31 \mathrm{a}$ \\
Mix & $10.75 \mathrm{a}$ & $20.94 \mathrm{a}$ & $98.25 \mathrm{a}$
\end{tabular}

${ }^{a}$ Means with the same letters in the same column are not significantly different based on the least squares mean separation $(p=0.01)$. 

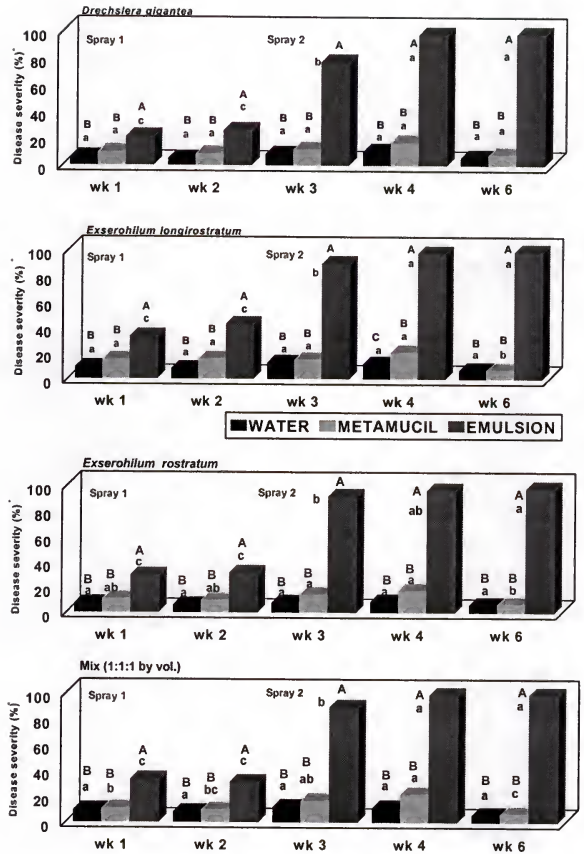

Figure 7-1. Effect of inoculation with Drechslera gigantea, Exserohilum longirostratum, $E$. rostratum, and a mixture of the three pathogens $(1: 1: 1 \mathrm{v} / \mathrm{v})$ on disease severity of guineagrass. Disease severity values denoted by the same letter do not differ significantly based on the least squares mean separation $(p=0.01)$. Lowercase letters represent effects of carriers over the weeks, and uppercase letters represent effects of carriers within each week. 

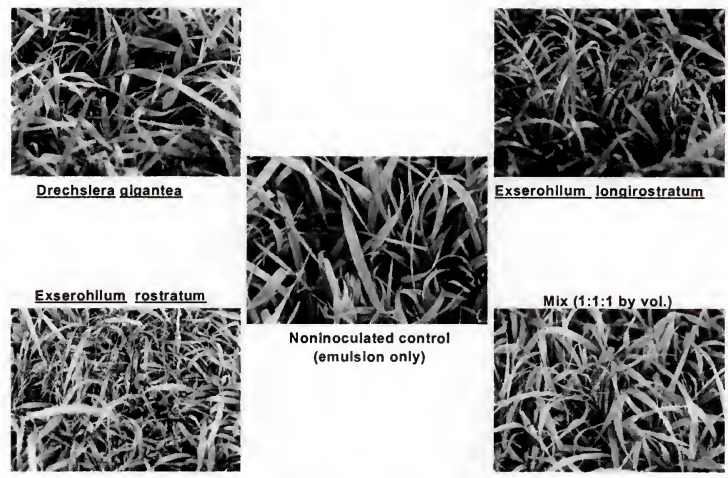

Figure 7-2. Effects of inoculation with Drechslera gigantea, Exserohilum longirostratum, E. rostratum, and a mixture of the three pathogens $(1: 1: 1 \mathrm{v} / \mathrm{v})$ on guineagrass under field conditions at 2 weeks after initial spray. 

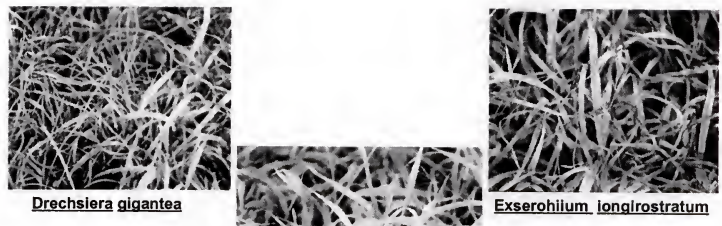

Exserohilum longirostratum
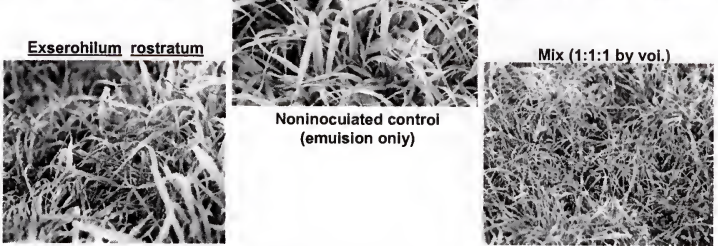

Figure 7-3. Effects of inoculation with Drechslera gigantea, Exserohilum longirostratum, E. rostratum, and a mixture of the three pathogens $(1: 1: 1 \mathrm{v} / \mathrm{v})$ on guineagrass under field conditions at 4 weeks after initial spray. 


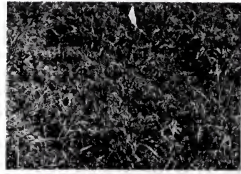

Drechslera gigantea

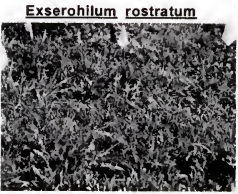

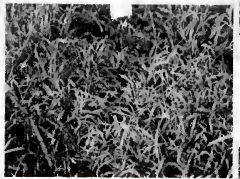

Noninoculated control (emulsion only)

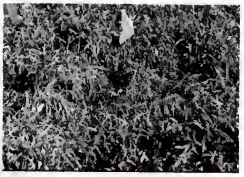

Exserohilum longirostratum

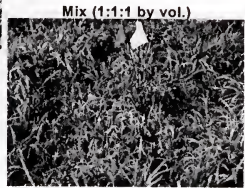

Figure 7-4. Effects of inoculation with Drechslera gigantea, Exserohilum longirostratum, E. rostratum, and a mixture of the three pathogens $(1: 1: 1 \mathrm{v} / \mathrm{v})$ on guineagrass under field conditions at 10 weeks after initial spray. 
mowing operations demand high input of energy. Also, mowing may indirectly aid in the spread of weed seeds and vegetative parts. Chemical weed control is the most effective means of weed management, but the effectiveness depends largely on timing and frequency of herbicide applications. Repeated applications are needed to kill established weeds. As weed species mature, dense growth and height make it difficult to achieve good spray coverage. Even two applications per year may not be enough for satisfactory level of weed control.

Guineagrass (narrow-leaf panicum) has become widespread in Florida citrus and is difficult to control. It is tolerant to postemergence applications of norflurazon in water-ring treatments or with micro-spinklers. The narrow-leaf biotype absorbed and translocated only low amounts of this herbicide. Also, it was able to degrade the herbicidal parent compound into its nonphytotoxic form, thereby preventing its accumulation in shoots. Demethylation was the primary mechanism involved in detoxification (Tamma \& Singh, 1987).

The susceptibility of guineagrass to chemical herbicides is variable. It is susceptible to preemergence herbicides such as terbacil (5-chloro-3-(1,1-dimethylethyl)-6-methyl2,4(1H,3H)-pyrimidinedione), bromacil (5-bromo-6-methyl-3-(1-methylpropyl)-2,4(1H, 3H) pyrimidinedione), trifluralin (2,6-dinitro-N,N-dipropyl-4-(trifuoromethyl) benzenamine), bromacil+diuron ( $\mathrm{N}^{\prime}$-(3,4-dichlorophenyl)-N,N-dimethylurea), and is partially susceptible to diuron and dichlobenil (2,6-dichlorobenzonitrile). It is tolerant to simazine (6-chloroN,N'-diethyl-1,3,5-triazine-2,4-diamine) (Crocker \& Tucker, 1996). Postemergence herbicides like sethoxydim (\{2-[1-(ethoxyimino) butyl]-5-[2-(ethylthio) propyl]-3-hydroxy2-cyclohexen-1-one $\})$ and fluazifop-butyl ( $\{(\mathrm{R})-2$-[4-[[5-(trifluoromethyl)-2-pyridinyl] oxy] phenoxy] propanoic acid\}) are used to control guineagrass and other weedy grasses. 
Guineagrass needs to be treated when 6-12 inches tall and repeat applications at 3-4 week intervals are necessary for satisfactory control (Tucker \& Singh, 1993). To overcome limitations of preemergence herbicides, glyphosate ( $\mathrm{N}$-(phosphonomethyl)glycine) was registered as a nonselective, systemic postemergence herbicide in citrus in Florida (Tucker, 1979) and it is the most popular postemergence herbicide currently used in Florida citrus production (Futch, 1997).

In view of the increased costs of chemical weed control and tolerance of guineagrass to available herbicides, an alternative method to improve control of guineagrass is desirable. Biological weed control is a viable, nonchemical alternative and a complementary strategy for weed management in citrus. Currently, there is no bioherbicide available for the control of any weedy grass. In studies in greenhouse, D. gigantea, E. longirostratum, and $E$. rostratum isolated from naturally diseased weedy grasses from different locations within Florida were highly efficacious to control guineagrass. In further investigations, the bioherbicidal pathogens were able to control guineagrass under field conditions. An emulsion-based inoculum preparation of the pathogens and a mixture of the three pathogens killed guineagrass ( $100 \%$ weed kill) . The individual pathogens and the pathogen mixture were equally effective. The disease severity level increased significantly after each spray, and two sprays were sufficient to kill guineagrass almost completely. The weed control lasted for 10 weeks without any regrowth of the weed. Thus, D. gigantea, E. longirostratum, and $E$. rostratum are highly effective in controlling a naturally established population of guineagrass in the field, when used alone or in a mixture. 


\section{CHAPTER VIII \\ SUMMARY AND CONCLUSIONS}

A bioherbicide is commonly a fungal or bacterial plant pathogen, used in an inundative biocontrol strategy. The pathogen is mass cultured, formulated, standardized, and applied pre- or postemergence when the weeds are at a susceptible growth stage (Chadrudattan, 1988a \& 1991). Although bioherbicides are practical weed-control agents, they have some disadvantages. For instance, the extreme level of host-specificity of most pathogens used as bioherbicides restricts their use to the control of only one or a narrow spectrum of weed species. In practice, this restricts the adoption of bioherbicides by growers accustomed to using broad-spectrum chemical herbicides to control several weeds at the same time. Secondly, an insufficient level of weed control may result, when a single pathogen is used. These problems can be overcome with a mixture of host-specific pathogens that are compatible among themselves, have similar requirements for disease development, and in a mixture are capable of affecting a number of different weeds. Thus, it is possible to use three or more host-specific pathogens that are combined and applied simultaneously to control several weeds. We have termed this approach the "multiplepathogen strategy".

The concept of using multiple pathogens to control simultaneously several weeds was tested on pigweed (Amaranthus hybridus L.), sicklepod (Senna obtusifolia (L.) Irwin \& Barneby), and showy crotalaria (Crotalaria spectabilis Roth.) by using four pathogens 
applied in a single, postemergent spray. The pathogens tested were Phomopsis amaranthicola sp. nov. (PA; pigweed pathogen), Alternaria cassiae Jurair and Khan (AC; major host, sicklepod; alternative host, showy crotalaria), Colletotrichum dematium (Penz. Ex. Fr.) Grove f.sp. crotalariae, and Fusarium udum (Butler) f.sp. crotalariae (Kulkarni) Subramanian (CD and FU; showy crotalaria pathogens). A spore suspension of each pathogen alone $\left(10^{6}\right.$ per $\left.\mathrm{ml}\right)$ and a mixture of the four pathogens $\left(1: 1: 1: 1 \mathrm{v} / \mathrm{v}\right.$, total $10^{6}$ spores per $\mathrm{ml}$ ) were tested on the weed seedlings that were grown together in pots. The pathogens completely controlled their respective weed hosts, when they were used individually or in a mixture. Scanning electron microscopy revealed that the developmental patterns of the pathogens were conditioned by specific interactions with the host leaf surface, whether the pathogens were applied alone or in a mixture. The leaf surface of each weed host was predominantly occupied by spores of its respective host-specific pathogen. AC caused extensive tissue maceration and rarely formed appressoria on its major host, sicklepod. It formed healthy germ tubes and multiple appressoria without any associated tissue maceration on showy crotalaria, its alternative host. AC developed appressoria on pigweed, a nonhost, but the appressoria lysed within $24 \mathrm{~h}$. CD formed healthy appressoria on showy crotalaria, whereas either appressorial lysis or poorly formed appressoria were observed on the nonhosts sicklepod and pigweed. PA germinated and grew only on pigweed. It did not grow on sicklepod or showy crotalaria. FU, although a root-pathogen, germinated and grew on showy crotalaria leaves, but not on leaves of its nonhosts. Therefore, it is possible to use several fungal plant pathogens in a mixture to control several weeds simultaneously without loss of efficacy and host-specificity of each pathogen. 
The most problematic weeds in Florida citrus are annual and perennial weedy grasses, which are among the worst weeds in many crops in several countries (Holm, 1977). They are: bahiagrass, Paspalum notatum Fluegge; bermudagrass, Cynodon dactylon (L.) Pers.; large crabgrass, Digitaria sanguinalis (L.) Scop.; crowfootgrass, Dactyloctenium aegyptium (L.) Willd.; goosegrass, Eleusine indica (L.) Gaertn.; guinegrass, Panicum maximum Jacq. (tall and short biotypes); johnsongrass, Sorghum halepense (L.) Pers.; napiergrass, Pennisetum purpureum Schumach.; natalgrass, Rhynchelytrum repens (Willd.) C.E.Hubb.; southern sandbur, Cenchrus echinatus L.; Texas panicum, Panicum texanum L.; torpedograss, Panicum repens L.; vaseygrass, Paspalum urvillei Steud.; and yellow foxtail, Setaria glauca (L.) Beauv. These grassy weeds cause yield losses in many other crops, besides citrus (Weller et al., 1985; Bridges and Chandler, 1987; Murphy et al., 1986). They are difficult to control, either because of their tolerance to available chemical herbicides or due to their growth habits that enable them to escape from other control practices. Narrowleaf guineagrass (Panicum maximum Jacq.) poses a major weed problem in citrus in Florida (Akins, 1994). The prolific spread of this weed and its tolerance to chemical control has warranted immediate alternative control measures.

Presently, no bioherbicides are available to control the many grasses that affect the citrus industry in Florida. However, several fungal plant pathogens have been reported to have potential as bioherbicides to control some of the weedy grasses that affect other crops: Sphacelotheca holci Jack. [=S. cruenta (Kuhn.) Potter] for johnsongrass (Massion \& Lindow, 1986); Bipolaris setariae (Saw.) and Pyricularia grisea (Cke.) Sacc. for goosegrass (Figliola et al., 1988); Exserohilum turcicum (Pass.) K.J. Leonard \& Suggs, Colletotrichum graminicola (Ces.) G.W. Wils., Gleoocercospora sorghi Bain \& Edgerton, and Bipolaris 
halepense Chiang, Leonard \& Van Dyke for johnsongrass (Chiang et al., 1989a); Bipolaris sorghicola (Lefebvre \& Sherwin) Alcorn and an unidentified species of Bipolaris for johnsongrass (Winder and Van Dyke, 1990); and Exerohilum monoceras (Drechs.) K.J. Leonard \& Suggs for Echinocloa spp. (Zhang and Watson, 1997a).

Discovery and development of host-specific fungal plant pathogens as bioherbicides should provide a nonchemical option for the management of weedy grasses. Accordingly, in this study the bioherbicidal control of several weedy grasses with a pathogen mixture was tested using three fungi indigenous to Florida. These were Drechslera gigantea (Heald \& Wolf) Ito, Exserohilum longirostratum (Subram.) Sivan., and Exserohilum rostratum (Drechsler) Leonard \& Suggs. These fungi were isolated respectively from large crabgrass, crowfootgrass, and johnsongrass. In trials conducted in a greenhouse, these pathogens controlled the following seven grasses: large crabgrass, crowfootgrass, guineagrass, johnsongrass, southern sandbur, Texas panicum, and yellow foxtail. A mixture of the three pathogens (1:1:1 by vol) was also tested. At $2 \times 10^{5}$ spores per ml, 4-wk old plants of all above grass species were almost completely controlled with both individual pathogens and the pathogen mixture.

Host-specificity of the bioherbicidal pathogens and safety of nontarget plants are crucial considerations in the development of any bioherbicidal agent. Therefore, host-range was determined for each of the pathogens (D. gigantea, E. longirostratum, and E. rostratum) as well as a mixture of all three pathogens. Important crop plants in the family Poaceae, which are reportedly hosts to pathogens of the genera Drechslera and Exserohilum, were resistant to these pathogens and the pathogen mixture. They developed noncoalescing necrotic flecks that disappeared over time. All other economically important crop plants 
tested were immune to all three pathogens and a mixture of the three pathogens (Table 4-1). Also, the crop plant species tested were safe against an emulsion-based inoculum preparation of the pathogen mixture (Table 4-2). Thus, D. gigantea, E. longirostratum, and E. rostratum and a mixture of all the three pathogens were nonpathogenic to the crop species tested.

A technique for mass production and multiple harvest of the three bioherbicidal fungi was developed to produce sufficient inoculum needed for field studies. Spores of the three bioherbicidal agents (D. gigantea, E. longirostratum, and E. rostratum) were produced using a biphasic culturing system. The spores were viable even after three years of storage as dry spores or in soil kept at $4^{\circ} \mathrm{C}$ (Appendix A).

The efficacy of the multiple-pathogen approach to control several weedy grasses was then tested in the field. The three pathogens, D. gigantea, E. longirostratum, and E. rostratum were tested individually and as a mixture of all three pathogens. During the experimental period of $14 \mathrm{wk}$, all treatments were reapplied twice (1996) and once (1998), at 2-3 wk intervals, following the initial spray. An emulsion-based inoculum preparation ( $40 \%$ oil concentration) of the individual pathogens and a mixture of the three pathogens almost completely controlled the seven weedy grasses under field conditions up to a period of 14 weeks without any significant regrowth. Similarly, the bioherbicidal control of a natural population of guineagrass with the pathogen mixture was field-tested. During the experimental period of $10 \mathrm{wk}$, all treatments were reapplied once at $2 \mathrm{wk}$ interval, following the initial spray. An emulsion-based inoculum preparation of individual pathogens and a mixture of the three pathogens almost completely controlled guineagrass in the field up to a period of 10 weeks without any significant regrowth. 
In conclusion, it is feasible to control several weeds (sicklepod, showy crotalaria, and pigweed) simultaneously with a mixture of host-specific fungal plant pathogens in a "multiple-pathogen strategy." Host-specific responses of pathogens studied in the model system appear to be conditioned by their interactions with the host leaf surfaces, when they were used alone or in a mixture. With the multiple-pathogen approach, it was possible to control several weedy grasses with $D$. gigantea, E. longirostratum, and E. rostratum, when used individually or in a mixture. These fungi were determined to be nonpathogenic to many nontarget crop species and could be mass-produced for large-scale application. It was feasible to control several weedy grasses under field conditions using the "multiple-pathogen strategy". The following weeds were almost completely controlled under field conditions by using an emulsion-based inoculum preparation of individual pathogens and a pathogen mixture: large crabgrass, crowfootgrass, johnsongrass, guineagrass, Texas panicum, southern sandbur, and yellow foxtail. The weed control lasted for more than 3 months. A natural population of guineagrass, a major weed in Florida citrus, was also almost completely controlled with two applications of an emulsion-based inoculum preparation of individual pathogens and a mixture of pathogens. Weed control lasted up to 2.5 months without any significant regrowth. Thus, efficacy of $D$. gigantea, E. longirostratum, and E. rostratum to effectively control several weedy grasses was demonstrated. Presently, there is no bioherbicide available to control weedy grasses. Therefore, these fungi could be commercially developed to control weedy grasses in tree crops such as citrus. 


\section{APPENDIX A}

EFFECT OF LONG TERM STORAGE ON SURVIVAL OF THREE BIOHERBICIDAL FUNGI, Drechslera gigantea, Exserohilum longirostratum, AND E.rostratum.

\begin{tabular}{|c|c|c|c|c|}
\hline Storage Conditions & $\begin{array}{l}\text { Duration } \\
\text { of Storage } \\
\text { (years) }\end{array}$ & D. gigantea & E. longirostratum & E. rostratum \\
\hline Soil & 3 & 100 & 100 & 100 \\
\hline Dry spores & 3 & 100 & 100 & 100 \\
\hline Agar slants & 3 & 0 & 0 & 0 \\
\hline
\end{tabular}

${ }^{\text {a }}$ Data represent an average of four replicates. 


\section{APPENDIX B}

EFFECT OF INOCULATION WITH Drechslera gigantea, Exserohilum longirostratum, E. rostratum, AND A MIXTURE OF ALL THREE PATHOGENS ON PANICLE NUMBER AT 14 WEEKS AFTER INOCULATION.

\begin{tabular}{lll}
\hline Weed & Isolate & No. of panicles \\
\hline Johnsongrass & Drechslera gigantea & $28.75 \mathrm{~b}$ \\
& Exserohilum longirostratum & $39.75 \mathrm{~b}$ \\
& Exserohilum rostratum & $34.75 \mathrm{~b}$ \\
& Mix $(1: 1: 1)$ & $24.50 \mathrm{~b}$ \\
& $\begin{array}{l}\text { Noninoculated Control } \\
\text { (40\% Emulsion alone) }\end{array}$ & $69.75 \mathrm{a}$ \\
& Drechslera gigantea & $0 \mathrm{~b}$ \\
& Exserohilum longirostratum & $10.25 \mathrm{~b}$ \\
& Exserohilum rostratum & $20.75 \mathrm{~b}$ \\
& Mix (1:1:1) & $7.00 \mathrm{~b}$ \\
& $\begin{array}{l}\text { Noninoculated Control } \\
\text { (40\% Emulsion alone) }\end{array}$
\end{tabular}

Data represents an average of 4 replicates; $\mathrm{SE} \pm 6.99$ 


\section{APPENDIX C}

WEATHER DATA

Maximum and Minimum Temperatures

Indian River Research and Education Center, Fort Pierce

Sep to Dec 1996

\begin{tabular}{|c|c|c|c|c|c|c|c|c|c|c|c|c|}
\hline & & Sep & & & Oct & & & Nov & & & Dec & \\
\hline Date & Max & Min & $P$ & $\operatorname{Max}$ & Min & $\mathrm{P}$ & Max & Min & $\mathrm{P}$ & Max & Min & $\mathrm{P}$ \\
\hline 1 & 94 & 74 & 0 & 88 & 72 & 0 & 88 & 64 & 0 & 78 & 60 & 0 \\
\hline 2 & 97 & 74 & 1.1 & 88 & 76 & 0 & 88 & 65 & 0 & 82 & 60 & 0 \\
\hline 3 & 97 & 72 & 0 & 88 & 73 & 0 & 87 & 59 & 0 & 77 & 59 & 0 \\
\hline 4 & 93 & 73 & 0 & 83 & 72 & 0 & 77 & 59 & 0 & 78 & 58 & 0 \\
\hline 5 & 92 & 73 & 0 & 85 & 72 & 0 & 84 & 75 & 2.05 & 76 & 52 & 0 \\
\hline 6 & 94 & 72 & 0 & 85 & 73 & 2.01 & 78 & 67 & 0 & 80 & 58 & 0 \\
\hline 7 & 94 & 72 & 0 & 84 & 73 & 0 & 86 & 68 & 0 & 85 & 61 & 0 \\
\hline 8 & 93 & 72 & 0.61 & 87 & 74 & 0.50 & 86 & 66 & 0 & 83 & 63 & 0.97 \\
\hline 9 & 91 & 72 & 0.75 & 82 & 69 & 0 & 88 & 52 & 0 & 68 & 40 & 0 \\
\hline 10 & 88 & 73 & 0.21 & 86 & 63 & 0 & 72 & 48 & 0 & 66 & 40 & 0 \\
\hline 11 & 88 & 72 & 0 & 84 & 61 & 0 & 73 & 48 & 0 & 73 & 41 & 0 \\
\hline 12 & 93 & 70 & 0 & 84 & 63 & 0 & 75 & 50 & 0 & 78 & 47 & 0 \\
\hline 13 & 91 & 70 & 0 & 84 & 72 & 0.23 & 75 & 54 & 0 & 81 & 53 & 0 \\
\hline 14 & 91 & 70 & 0 & 82 & 70 & 0 & 79 & 69 & 0 & 81 & 53 & 0 \\
\hline 15 & 94 & 71 & 0 & 87 & 69 & 1.14 & 80 & 71 & 0 & 76 & 55 & 0 \\
\hline 16 & 91 & 71 & 0.23 & 84 & 72 & 2.47 & 78 & 69 & 0.05 & 76 & 52 & 0 \\
\hline 17 & 93 & 71 & 0.55 & 84 & 72 & 0 & 79 & 67 & 0.30 & 77 & 50 & 0 \\
\hline 18 & 90 & 73 & 0 & 84 & 71 & 0 & 77 & 67 & 0.02 & 80 & 50 & 0 \\
\hline 19 & 87 & 72 & 0 & 84 & 69 & 0 & 77 & 62 & 0 & 80 & 53 & 0.25 \\
\hline 20 & 93 & 72 & 0 & 77 & 55 & 0 & 84 & 58 & 0 & 72 & 37 & 0 \\
\hline 21 & 91 & 72 & 0.68 & 81 & 54 & 0 & 84 & 58 & 0 & 53 & 36 & 0 \\
\hline 22 & 88 & 74 & 0 & 84 & 56 & 0 & 85 & 59 & 0 & 66 & 50 & 0 \\
\hline 23 & 86 & 70 & 0 & 84 & 60 & 0 & 78 & 50 & 0 & 77 & 51 & 0.07 \\
\hline 24 & 86 & 64 & 0 & 89 & 66 & 0 & 77 & 52 & 0 & 79 & 55 & 0 \\
\hline 25 & 88 & 64 & 0 & 90 & 63 & 0 & 78 & 62 & 0 & 78 & 48 & 0 \\
\hline 26 & 87 & 64 & 0 & 85 & 64 & 0 & 83 & 64 & 0.05 & 75 & 48 & 0 \\
\hline 27 & 88 & 73 & 0 & 87 & 72 & 0 & 83 & 50 & 0.08 & 83 & 55 & 0 \\
\hline 28 & 88 & 68 & 0 & 86 & 67 & 0 & 79 & 50 & 0 & 81 & 60 & 0 \\
\hline 29 & 90 & 68 & 2.47 & 87 & 63 & 0 & 77 & 61 & 0 & 86 & 56 & 0 \\
\hline 30 & 90 & 70 & 0.61 & 87 & 62 & 0 & 77 & 65 & 0 & 83 & 56 & 0.36 \\
\hline 31 & - & - & - & 92 & 65 & 0 & - & - & - & 82 & 58 & 0 \\
\hline
\end{tabular}

Max $=$ maximum temperature in degrees $\mathrm{F}$.

$\mathrm{Min}=$ minimum temperature in degrees $\mathrm{F}$.

$\mathrm{P}=$ precipitation in inches. 
Maximum and Minimum Temperatures

Indian River Research and Education Center, Fort Pierce

Apr to July 1998

\begin{tabular}{|c|c|c|c|c|c|c|c|c|c|c|c|c|}
\hline & & Apr & & & May & & & June & & & July & \\
\hline Date & Max & Min & $P$ & Max & Min & $P$ & Max & Min & $P$ & Max & Min & $P$ \\
\hline 1 & 84 & 70 & 0 & 90 & 68 & 0 & 92 & 72 & 0 & 101 & 72 & 0 \\
\hline 2 & 85 & 68 & 0 & 87 & 62 & 0 & 95 & 73 & 0 & 101 & 74 & 0 \\
\hline 3 & 88 & 66 & 0 & 89 & 56 & 0 & 98 & 74 & 0 & 98 & 70 & 0.93 \\
\hline 4 & 88 & 69 & 0 & 93 & 57 & 0 & 98 & 70 & 0 & 98 & 73 & 0 \\
\hline 5 & 88 & 56 & 0 & 90 & 61 & 1.37 & 99 & 70 & 0 & 94 & 74 & 0 \\
\hline 6 & 80 & 53 & 0 & 90 & 62 & 0 & 100 & 74 & 0 & 96 & 74 & 0 \\
\hline 7 & 81 & 57 & 0 & 91 & 65 & 0 & 99 & 70 & 1.81 & 98 & 75 & 0.30 \\
\hline 8 & 82 & 63 & 0 & 91 & 68 & 0 & 97 & 69 & 0 & 96 & 73 & 0 \\
\hline 9 & 87 & 69 & 0 & 92 & 72 & 0 & 86 & 72 & 0 & 96 & 73 & 0 \\
\hline 10 & 89 & 59 & 0 & 92 & 66 & 0 & 88 & 73 & 0 & 98 & 74 & 0 \\
\hline 11 & 81 & 55 & 0 & 92 & 71 & 0 & 93 & 72 & 0 & 94 & 76 & 0 \\
\hline 12 & 72 & 53 & 0 & 90 & 64 & 0 & 94 & 73 & 0 & 93 & 74 & 0.69 \\
\hline 13 & 77 & 54 & 0 & 87 & 63 & 0 & 98 & 74 & 0 & 98 & 73 & 0 \\
\hline 14 & 75 & 55 & 0 & 89 & 62 & 0 & 97 & 75 & 0 & 93 & 74 & 0.14 \\
\hline 15 & 83 & 55 & 0 & 85 & 64 & 0 & 99 & 76 & 0 & 88 & 75 & 0 \\
\hline 16 & 85 & 57 & 0 & 84 & 59 & 0 & 98 & 70 & 0 & 86 & 70 & 0.79 \\
\hline 17 & 85 & 65 & 0 & 85 & 58 & 0 & 97 & 72 & 0.08 & 96 & 70 & 0 \\
\hline 18 & 89 & 64 & 0 & 86 & 59 & 0 & 95 & 74 & 0 & 97 & 73 & 0 \\
\hline 19 & 85 & 71 & 0 & 90 & 60 & 0 & 99 & 72 & 0 & 96 & 73 & 0 \\
\hline 20 & 90 & 65 & 1.77 & 91 & 67 & 0 & 98 & 73 & 0.82 & 93 & 72 & 0.19 \\
\hline 21 & 89 & 65 & 0.30 & 91 & 67 & 0 & 97 & 71 & 0 & 92 & 73 & 0.39 \\
\hline 22 & 81 & 60 & 0 & 96 & 65 & 0 & 97 & 70 & 0 & 91 & 70 & 0 \\
\hline 23 & 84 & 52 & 0 & 96 & 67 & 0 & 93 & 74 & 0 & 90 & 70 & 0 \\
\hline 24 & 77 & 51 & 0 & 94 & 67 & 0 & 93 & 76 & 0 & 93 & 72 & 0 \\
\hline 25 & 80 & 51 & 0 & 91 & 66 & 0 & 93 & 73 & 0 & 93 & 73 & 0 \\
\hline 26 & 79 & 57 & 0 & 94 & 71 & 0 & 96 & 74 & 0.43 & 93 & 74 & 0 \\
\hline 27 & 81 & 59 & 0 & 93 & 75 & 0 & 98 & 70 & 0 & 94 & 73 & 0 \\
\hline 28 & 83 & 67 & 0 & 91 & 73 & 0.42 & 93 & 70 & 0 & 95 & 74 & 0 \\
\hline 29 & 85 & 69 & 0 & 85 & 70 & 0 & 96 & 71 & 0 & 100 & 75 & 0 \\
\hline 30 & 81 & 68 & 0.40 & 89 & 70 & 0 & 94 & 74 & 0 & 97 & 73 & 0 \\
\hline 31 & - & - & - & 88 & 71 & 0.63 & - & - & - & 96 & 74 & 0 \\
\hline
\end{tabular}


Maximum and Minimum Temperatures

Indian River Research and Education Center, Fort Pierce Aug to Oct 1998

\begin{tabular}{|c|c|c|c|c|c|c|c|c|c|}
\hline & & Aug & & & Sep & & & Oct & \\
\hline Date & Max & Min & $P$ & Max & Min & $P$ & Max & Min & $\mathrm{P}$ \\
\hline 1 & 96 & 72 & 0 & 96 & 72 & 0 & 93 & 73 & 0 \\
\hline 2 & 95 & 72 & 0.46 & 98 & 72 & 0 & 93 & 75 & 0 \\
\hline 3 & 94 & 72 & 2.89 & 93 & 73 & 0.23 & 94 & 73 & 0 \\
\hline 4 & 95 & 72 & 0.99 & 95 & 75 & 0 & 97 & 70 & 0 \\
\hline 5 & 95 & 73 & 1.20 & 98 & 75 & 0.92 & 94 & 70 & 0 \\
\hline 6 & 94 & 71 & 0.76 & 91 & 74 & 0 & 91 & 73 & 0 \\
\hline 7 & 92 & 72 & 0 & 93 & 75 & 0 & 91 & 72 & 0 \\
\hline 8 & 93 & 75 & 0 & 92 & 75 & 0.14 & 90 & 72 & 0 \\
\hline 9 & 93 & 76 & 0 & 95 & 73 & 0.22 & 89 & 72 & 0 \\
\hline 10 & 91 & 76 & 0 & 95 & 73 & 0.32 & 94 & 73 & 0 \\
\hline 11 & 93 & 74 & 0 & 87 & 78 & 0 & 90 & 71 & 0.60 \\
\hline 12 & 97 & 74 & 0 & 87 & 69 & 0 & 94 & 71 & 0.05 \\
\hline 13 & 97 & 76 & 0 & 85 & 69 & 0.05 & 88 & 70 & 0 \\
\hline 14 & 99 & 74 & 0 & 87 & 69 & 0.10 & 88 & 68 & 0 \\
\hline 15 & 98 & 73 & 1.00 & 88 & 71 & 1.20 & 85 & 67 & 0 \\
\hline 16 & 96 & 73 & 0 & 89 & 74 & 0.41 & 87 & 68 & 0 \\
\hline 17 & 92 & 75 & 0 & 83 & 74 & 0.54 & 87 & 75 & 0 \\
\hline 18 & 93 & 77 & 0 & 90 & 75 & 0 & 85 & 74 & 0.40 \\
\hline 19 & 93 & 75 & 0 & 91 & 76 & 0 & 85 & 70 & 0.43 \\
\hline 20 & 91 & 76 & 1.98 & 92 & 75 & 2.25 & 86 & 72 & 0.08 \\
\hline 21 & 88 & 75 & 0 & 95 & 75 & 0 & 87 & 73 & 0.13 \\
\hline 22 & 90 & 73 & 2.25 & 99 & 73 & 0.35 & 90 & 73 & 0.01 \\
\hline 23 & 94 & 78 & 0 & 96 & 73 & 0 & 85 & 71 & 0 \\
\hline 24 & 94 & 74 & 0 & 93 & 74 & 0.12 & 80 & 71 & 0 \\
\hline 25 & 92 & 75 & 0 & 90 & 75 & 0.15 & 82 & 72 & 0 \\
\hline 26 & 97 & 73 & 0 & 88 & 81 & 0 & 84 & 69 & 0.19 \\
\hline 27 & 101 & 74 & 0 & 90 & 77 & 0 & 82 & 70 & 0 \\
\hline 28 & 98 & 76 & 0 & 91 & 73 & 0 & 83 & 63 & 0 \\
\hline 29 & 96 & 76 & 0 & 90 & 71 & 0 & 83 & 59 & 0 \\
\hline 30 & 92 & 72 & 0 & 90 & 71 & 0 & 84 & 55 & 0 \\
\hline 31 & 93 & 71 & 0.24 & - & - & - & 87 & 57 & 0 \\
\hline
\end{tabular}

Max $=$ maximum temperature in degrees $\mathrm{F}$.

$\mathrm{Min}=$ minimum temperature in degrees $\mathrm{F}$.

$\mathrm{P}=$ precipitation in inches. 


\section{REFERENCES}

Angra-Sharma, and Sharma. 1994. Biochemical and histological studies on susceptible and resistant maize leaves infected by Helminthosporium maydis. Plant Pathol. 43:972-978.

Akins, R. 1994. As narrow-leaf panicum spreads, researchers seek improved control. Citrus Industry. 2 pp.

Alcorn, J.L. 1988. The taxonomy of "Helminthosporium" species. Ann. Rev. Phytopathol. 26:37-56.

Amsellem, Z., Sharon, A., and Gressel, J. 1991. Abolition of selectivity of two mycoherbicidal organisms and enhanced virulence of avirulent fungi by an invert emulsion. Phytopathol. 81:985-988.

Amsellem, Z., Sharon, A., Gressel, J., and Qumby, P.C. Jr. 1990. Complete abolition of high inoculum threshold of two mycoherbicides (Alternaria cassiae and A. crassa) when applied in invert emulsion. Phytopathol. 80:925-929.

Anderson, R.N., and Walker, H.L. 1985. Colletotrichum coccodes: a pathogen of eastern black nightshade (Solanum ptycanthum). Weed Sci. 33:902-905.

Arase, S., and Fujita, K. 1992. Induction of inaccessibility to Pyricularia oryzae by preinoculation of $P$. grisea in rice leaf-sheath cells. J. Phytopathol. 134:97-102.

Auld, B.A. 1992. Development and commercialization of biocontrol agents. Pages 269-272 in: Proc. First Intl. Weed Control Congr. J.H. Combellack, ed. Agmedia, Melbourne, Australia.

Auld, B.A. 1993. Vegetable oil suspension emulsions reduce dew dependency of a mycoherbicide. Crop Prot. 12:477-479.

Auld, B.A. 1997. Mass production of fungi for biopesticides. Pages 135-140 in: Biological Control of Weeds: Theory and Application. M. Julien, and G. White, eds. ACIAR Monograph No. 49.

Auld, B.A., and Morin, L. 1995. Constraints in the development of bioherbicides. Weed Technol. 9:638-652. 
Auld, B.A., Talbot, H.E., and Radburn, K.B. 1994. Resistance of Xanthium occidentale to Colletotrichum orbiculare, a pathogen of Xanthium spinosum. Aust. J. Bot. 42:19-28.

Baird, D.D., Urrutia, V.M., and Tucker, D.P.H. 1983. Management systems with glyphosate on torpedograss in citrus. Proc. South. Weed Sci. Soc. 36:201-209.

Baker, K.F., and Cook, R.J. 1974. Biological Control of Plant Pathogens. W.H. Freeman \& Co. San Francisco, CA. 433 pp.

Baker, C.A., and Henis, J.M.S. 1990. Commercial production and formulation of microbial biocontrol agents. Pages 333-344 in: New Directions in Biological Control: Alternatives for Suppressing Agricultural Pests and Diseases. R.R. Baker, and P.E. Dunn, eds. A.R. Liss, Inc., New York, NY.

Ballio, A. 1991. Non-host-selective fungal phytotoxins: biochemical aspects of their mode of action. Experientia 47:783-790.

Barrentine, W.L., and McWhorter, C.G. 1988. Johnsongrass (Sorghum halepense) control with herbicides in oil diluents. Weed Sci. 36:102-110.

Barreto, R.W., and Evans, H.C. 1992. Fungal pathogens of weeds collected in the Brazilian tropics and subtropics and their biological control potential. Pages 679-691 in: Proceedings of the Eight International Symposium on Biological Control of Weeds. Lincoln University, Canterbury, New Zealand. E.S. Delfosse, and R.R. Scott, eds. DSIR/CSIRO, Melbourne, Australia.

Barrett, J.A. 1983. Plant-fungus symbioses. Pages 137-160 in: Coevolution. D.J. Futuyma and M. Slatkin, eds. Sinaur Assoc. Inc., Sunderland, MA.

Baudoin, A.B.A.M., Abad, R.G., Kok, L.T., and Bruckart, W.L. 1993. Field evaluation of Puccinia carduorum for biological control of musk thistle. Biol. Control 3:53-60.

Beier, R.C., Mundy, B.P., and Strobel, G.A. 1982. Helminthosporoside, a host-specific toxin from Helminthosporium sacchari. Experientia 38:1312-1313.

Bendixen, L.E. 1986. Corn (Zea mays) yield in relationship to Johnsongrass (Sorghum halepense) population. Weed Sci. 34:449-451.

Berger, R.D., Benjamin, F.A., and Amorim, L. 1997. Lesion expansion as an epidemic component. Phytopathol. 87:1005-1013.

Bothast, R.J., Schisler, D.A., Jackson, M.A., VanCauwenberge, J.E., and Slininger, P.J. 1993. Use of pregelatinized starch and other polysaccharides for improved storage and efficacy of biocontrol agents. Pages 45-56 in: Pesticide Formulations and Application Systems: Vol. 13. P.D. Berger, B.N. Devisetty, and F.R. Hall, eds. American Society for 
Testing Materials, Philadelphia, PA.

Bowles, D.J. 1990. Defense-related proteins in higher plants. Annu. Rev. Biochem. 59:873-907.

Boyette, C.D. 1987. Biocontrol of hemp sesbania [Sesbania exaltata (Raf.) Cory.] by an induced host range alteration of Alternaria crassa. WSSA Abstracts 27:48.

Boyette, C.D. 1994. Unrefined corn oil improved the mycoherbicidal activity of Colletotrichum truncatum for hemp sesbania (Sesbania exaltata) control. Weed Technol. 8:526-529.

Boyette, C.D., Quimby, P.C. Jr., Connick, W.J. Jr., Daigle, D.J., and Fulgham, F.E. 1991a. Progress in the production, formulation and application of mycoherbicides. Pages 209-222 in: Microbial Control of Weeds. D.O. TeBeest, ed. Chapman Hall, New York, NY.

Boyette, C.D., Templeton, G.E., and Smith, R.J. 1979. Control of winged water primrose (Jussiae decurrens) and northern jointvetch (Aeschynomene virginica) with fungal pathogens. Weed Sci. 27:497-501.

Boyette, C.D., and Walker, H.L. 1985. Factors influencing biocontrol of velvetleaf (Abutilon theophrasti) and prickly sida (Sida spinosa) with Fusarium lateritium. Weed Sci. 33:209-211.

Boyette, C.G., Weidemann, G.J., Te Beest, D.O., and Quimby, P.C., Jr. 1991b. Biological control of jimsonweed (Datura stramonium) with Alternaria crassa. Weed Sci. 39:678-681.

Boyette, C.D., Quimby, P.C. Jr., Bryson, C.T., Egley, G.H., and Fulgham, F.E. 1993. Biological control of hemp sesbania (Sesbania exaltata) under field conditions with Colletotrichum truncatum formulated in an invert emulsion. Weed Sci. 41:497-500.

Bridges, D.C., and Chandler, J.M. 1987. Influence of Johnsongrass (Sorghum halepense) density and period of competition on cotton yield. Weed Sci. 35:63-67.

Burge, M.N. 1998. The scope of fungi in biological control. Pages 3-18 in: Fungi in Biological Control Systems. M.N. Burge, ed. Manchester Univ. Press, Manchester, U.K.

Cardina, J., and Littrell, R. 1986. Enhancement of anthracnose severity on Florida beggarweed [Desmodium tortuosum S. W. (D. C.)]. WSSA Abstracts 26:51.

Carson, M.L. 1995. A new gene in maize conferring the "chlorotic halo" reaction to infection by Exserohilum turcicum. Plant Dis. 79:717-720.

Chandramohan, S., and Charudattan, R. 1996. Mulitple-Pathogen Strategy for bioherbicidal control of several weeds. WSSA Abstracts 36:49. 
Charudattan, R. 1985. The use of natural and genetically altered strains of pathogens for weed control. Pages 347-372 in: Biological Control in Agricultural IPM Systems. M.A. Hoy and D.C. Herzog, eds. Academic Press Inc., Orlando, FL.

Charudattan, R. 1986. Integrated control of waterhyacinth with a pathogen, insects, and herbicides. Weed Sci. 34(Suppl. 1):26-30.

Charudattan, R. 1988a. Inundative control of weeds with indigenous fungal pathogens. Pages 86-110 in: Fungi in Biological Control Systems. M.N.Burge ed. Manchester University Press, Manchester, U.K.

Charudatan, R. 1988b. Assessment of efficacy of mycoherbicide candidates. Pages 455464 in: Proceedings of the VII Intl. Symp. on Biol. Control of Weeds, 6-11 March, 1988, Rome, Italy. CSIRO Publ., Victoria, Australia.

Charudattan, R. 1990. Pathogens with potential for weed control. Pages 132-154 in: Microbes and Microbial Products as Herbicides. R.E. Hoagland ed., ACS Symposium Series No. 439. American Chemical Society, Washington, DC.

Charudattan, R. 1991. The mycoherbicide approach with plant pathogens. Pages 24-57 in: Microbial Control of Weeds. D.O. Te Beest, ed. Chapman and Hall, New York, NY.

Charudattan, R., Linda, S.B., Kluepfel, M., and Osman, Y.A. 1985. Biocontrol efficacy of Cercospora rodmanii on waterhyacinth. Phytopathol. 75:1263-1269.

Charudattan, R., Prange, V.J., and DeValerio, J.T. 1996. Exploration of the use of "Bialaphos Genes" for improving bioherbicide efficacy. Weed Technol. 10:625-636.

Charudattan, R., Walker, H.L., Boyette, C.D., Ridings, W.H., Te Beest, D.O., Van Dyke, C.G., and Worsham, A.D. 1986. Evaluation of Alternaria cassiae as a mycoherbicide for sicklepod (Cassia obtusifolia) in regional field tests. Southern Coop. Ser. Bull. 317. Alabama Agric. Exp. Station, Auburn Univ., Auburn, AL, USA.

Chaurasia, S., Chand, R., and Joshi, A.K. 1998. A simple technique for the induction of sporulation in Alternaria triticina, incitant of leaf blight of wheat. Zeitschrift fur Pflanzkrankheiten and Pflanzenschutz. 105:17-21.

Chiang, M., Van Dyke, C.G., and Chilton, W.S. 1989a. Four foliar pathogenic fungi for controlling seedling johnsongrass (Sorghum halepense). Weed Sci. 37:802-809.

Chiang, M, Van Dyke, C.G., and Leonard, J.K. 1989b. Evaluation of endemic foliar fungi for potential control of johnsongrass [Sorghum halepense (L.) Pers.]: screening and hostrange tests. Plant Dis. 73:459-464. 
Churchill, B.W. 1982. Mass production of microorganisms for biological control. Pages 139-156 in: Biological Control of Weeds with Plant Pathogens. R. Charudattan and H. L. Walker, eds. John Wiley and Sons, New York, NY.

Connick, W.J., Jr., Boyette, C.D., and McAlpine, J.R. 1991a. Formulation of mycoherbicides using a pasta-like process. Biol. Control 1:281-287.

Connick, W.J. Jr., Daigle, D.J., and Quimby, P.C. Jr. 1991b. An improved invert emulsion with high water retention for mycoherbicide delivery. Weed Technol. 5:442-444.

Connick, W.J., Jr., Lewis, J.A., and Quimby, P.C., Jr. 1990. Formulation of biocontrol agents for use in plant pathology. Pages 345-372 in: New Directions in Biological Control: Alternatives for Suppressing Agricultural Pests and Diseases. R. R. Baker and P.E. Dunn, eds. A.R. Liss, New York, NY.

Conway, K.E., Freeman, T.E., and Charudattan, R. 1978. Methods and compositions for controlling waterhyacinth. U.S. Patent No. 4,097,261.

Cook, R.J., Bruckart, W.L., Coulson, J.R., Goettel, M.S., Humber, R.A., Lumsden, R.D., Maddox, J.V., Mc Manus, M.L., Moore, L., Meyer, S.F., Quimby, P.C. Jr., Stack, J.P., and Vaughn, J.C. 1996. Safety of microorganisms intended for pest and plant disease control: a framework for scientific evaluation. Biol. Control 7:333-351.

Cooper, R.M. 1981. Pathogen-induced changes in host ultrastructure. Pages 105-142 in: Plant Disease Control. R.C. Staples and G.H. Toenniessen, eds. John Wiley \& Sons, New York, NY.

Cotty, P.J. 1987. Modulation of sporulation of Alternaria tagetica by carbon dioxide. Mycologia 79:508-513.

Crawley, D.K., and Walker, H.L. 1983. Interaction of two fungal pathogens of spurred anoda. Proc. South. WSSA Abstracts 36:136.

Crocker, T.E., and Tucker, D.P.H. 1996. Susceptibility of weeds to herbicides: annual, broadleaf, perennial and woody. Institute of Food and Agricultural sciences. Fact Sheet HS97, Florida Cooperative Extension Service, University of Florida, Gainesville, FL, USA.

Cuq, F., Herrmann-Gorline, S., Klaebe, A., Rossignol, M., and Petitprez, M. 1993. Monocerin in Exserohilum turcicum isolates from maize and a study of its phytotoxicity. Phytochem. 34:1265-1270.

Daigle, D.J., and Connick, W.J. Jr. 1990. Microbial weed control. Pages 288-304 in: Microbes and Microbial Products as Herbicides. R.E. Hoagland ed., ACS Symposium Series No. 439. American Chemical Society, Washington, DC. 
Daigle, D.J., Connick, W.J. Jr., Quimby, P.C. Jr., Evans, J., Trask-Morrell, B., and Fulgham, F.E. 1990. Invert emulsions: carrier and water source for the mycoherbicide, Alternaria cassiae. Weed Technol. 4:327-331.

Daniel, J.T., Templeton, G.E., Smith, R.J., and Fox, W.T. 1973. Biological control of northern jointvetch in rice with an endemic fungal disease. Weed Sci. 21:303-307.

Dao, T. H. 1987. Crop residues and management of annual grass weeds in continuous no till wheat (Triticum aestivum). Weed Sci. 35:395-400.

De Nooij, M.P., and Paul, N.D. 1992. Invasion of rust (Puccinia poarum) pycnia and aecia on coltsfoot (Tussilago farfara) by secondary pathogens: Death of host leaves. Mycol. Res. 96: 309-312.

Dhingra, O.D., and Sinclair, J.B. 1995. Basic Plant Pathology Methods, Lewis Publishers, Boca Raton, Florida. 434 pp.

Egley, G.H., and Boyette, C.D. 1995. Water-corn oil emulsion enhances conidia germination and mycoherbicidal activity of Colletotrichum truncatum. Weed Sci. 43:312317.

Emmett, R.W., and Parbery, D.G. 1975. Appressoria. Ann. Rev. Phytopathol. 13:147-167.

Fernando, W.G.D., Watson, A.K., and Paulitz, T.C. 1994. Phylloplane Pseudomonas spp. enhance disease caused by Colletotrichum coccodes on velvetleaf. Biol. Control 4:125-131.

Figliola, S.S., Camper,N.D., and Ridings, W.H. 1988. Potential biological control agents for goosegrass (Eleusine indica). Weed Sci. 36:830-835.

Foy, C.L. 1989. Adjuvants: terminology, classification and mode of action. Pages 1-15 in: Adjuvants and Agrochemicals Vol. I., P.N.P. Chow, C.A. Grant, A.M. Hinshalwood, and E. Simundsson, eds. CRC Press, Boca Raton, FL.

Fravel, D.R., and Lewis, J.A. 1992. Production, formulation and delivery of beneficial microbes for biocontrol of plant pathogens. In: Pesticide Formulations and Application Systems. Vol. 11. L.E. Bode and D.G. Chasin, eds. ASTM STP 1112, American Society for Testing Materials, Philadelphia, PA.

Fravel, D.R., Marois, J., Lumsden, R., and Connick, W.J. 1985. Encapsulation of potential biocontrol agents in an alginate-clay matrix. Phytopathol. 75:774-777.

Futch, S.H. 1997. Horticultural and environmental aspects of weed control in Florida citrus. Ph. D. Thesis. Univ. Of Florida, Gainesville, FL, USA. 142pp. 
Futch, S.H., Singh, M., and Tucker, D.P.H. 1999. 1999 Florida Citrus Pest Management Guide: Weeds. Pages 27.1-27.4 in: 1999 Florida Citrus Pest management Guide. J.L. Knapp ed. Institute of Food and Agricultural Sciences, University of Florida, Gainesville, FL, USA.

Garrett, S.D. 1965. Toward biological control of soil-borne plant pathogens. Pages 4-17 in: Ecology of Soil-borne Plant Pathogens. K.F. Baker, ed. Univ. of Calif. Press, Berkeley, CA.

Gillespie, G.R., and Nalewaja, J.D. 1986. Postemergence grass control herbicides applied to the soil. Weed Sci. 34:942-947.

Gomez, K.A., and Gomez, A.A. 1984. Statistical Procedures for Agricultural Research. $2^{\text {nd }}$ edition. John Wiley and Sons, NY. 680pp.

Grant, N.T., Prusinkiewicz, E., Makowski, R.M.D., Holmstrom-Ruddick, B., and Mortensen, K. 1990. Effect of selected pesticides on survival of Colletotrichum gloeosporioides $\mathrm{f} . \mathrm{sp}$. malvae, a bioherbicide for round-leaved mallow (Malva pusilla). Weed Technol. 4:701715 .

Greaves, M.P., and Macqueen, M.D. 1990. The use of mycoherbicides in the field. Aspects of Appl. Biol. 24:163-168.

Greaves, M.P., Bailey, J.A., and Hargreaves, J.A. 1989. Mycoherbicides: Opportunities for genetic manipulation. Pestic. Sci. 26:93-101.

Green, S., Stewart-Wade, S.M., Boland, G.J., Teshler, M.P., and Liu, S.H. 1998. Formulating microorganisms for biological control of weeds. Pages 249-281 in: PlantMicrobe Interactions and Biological Control. G.J. Boland and L.D. Kuykendall, eds. Marcel Dekker, Inc., New York, NY.

Haasz, D., Frey, R., Thiesen, M., and Kauss, H. 1981. Partial purification of a hemagglutinin associated with cell walls from hypocotyls of Vigna radiata. Planta 151:490496.

Hall, D.W., Currey, W.L., and Orsenigo, J.R. 1998. Weeds from other places: The Florida beachhead is established. Weed Technol. 12:720-725.

Hallet, S.G. 1991. "A Dual Pathogen Strategy for the Biological Control of Weeds". Ph.D. Thesis, University of Lancaster, Lancaster, U.K.

Hallet, S.G., Paul, N.D., and Ayres, P.G. 1990. Botrytis cinerea kills groundsel (Senecio vulgaris) infected by rust (Puccinia laganophorae). New Phytol. 114:105-109. 
Hallet, S.G., Paul, N.D., and Ayres, P.G. 1992. Invasion of rust (Puccinia lagenophorae) aecia on groundsel (Senecio vulgaris) by secondary pathogens: Death of the host. Mycol. Res. 96:142-144.

Hallock, Y.F., Lu, H.S.M., Clardy, J., Strobel, G.A., Sugawara, F., Samsoedin, R., and Yoshida, S. 1993. Triticones, spirocyclic lactams from the fungal plant pathogen Drechslera tritici-repentis. J. Natl. Products 56:747-754.

Harman, G.E., Jin, X., Stasz, T.E., Peruzzotti, G., Leopold, A.C., and Taylor, A.G. 1991. Production of conidial biomass of Trichoderma harzianum for biological control. Biol. Control 1:23-28.

Harris, P., and Zwolfer, H. 1968. Screening of phytophagous insects for biological control of weeds. Canadian Entomol. 100:295-303.

Hasseltine, C.W. 1977. Solid state fermentation. Process Biochem. 12:24-27.

Heap, I.M. 1997. http://www.pioneer.net/ heapian/

Hetherington, S., Auld, B., Priest, M., Smith, H., Van Tuat, N., and Van Du, P. 1996. Preliminary surveys and pathogenicity testing of fungi isolated from the annual grass weeds Avena spp. and Lolium rigidum. Pages 1-11 in: Biological Control of Grass Weeds with Fungi as Bioherbicides. Bioherbicide Project Paper: Number 1. ACIAR, Australia.

Hofmeister, F.M., and Charudattan, R. 1987. Pseudocercospora nigricans, a pathogen of sicklepod (Cassia obtusifolia) with biocontrol potential. Plant Dis. 71:44-46.

Holcomb, G.E. 1982. Constraints on disease development. Pages 61-71 in: R. Charudattan and H.L. Walker, eds. Biological Control of Weeds with Plant Pathogens. John Wiley and Sons, New York.

Holm, L.G., Pluchnett, D.L., Pancho, J.V., and Herberger, J.P. 1977. The World's Worst Weeds: Distribution and Biology. The Univ. Press of Hawaii, Honolulu, Hawaii. 609pp.

Horsfall, J.G., and Barratt, R.W. 1945. An improved grading system for measuring plant disease. Phytopathol. 35:655 (Abstr).

Horsfall, J.G., and Cowling, E.B. 1978. Pathometry: The measurement of plant disease. Pages 119-136 in: Plant Diseases: An Advance Treatise. Vol. 2. J.G. Horsfall and E.B. Cowling, eds. Academic Press, New York, NY.

Howard, R.J., Ferrari, M.A., Roach, D.H., and Money, D.H. 1991. Penetration of hard substances by a fungus employing enormous turgor pressure. Proc. Natl. Acad. Sci. USA. $88: 11281-11284$. 
Hull, H.M., Davis, D.G., and Stolzenberg, G.E. 1982. Action of adjuvants on plant surfaces. Pages 26-67 in: Adjuvants for Herbicides. R.H. Hodgson, ed. Weed Sci. Soc. Am., Champaign, IL, USA.

Ito, S. 1930. On some new ascigerous stages of the species of Helminthosporium parasitic on cereals. Proc. Imp. Acad. (Tokyo) 6:352-355.

Jackson, M.A., Schisler, D.A., Slininger, P.J., Boyette, C.D., Silman, R.W., and Bothast, R.J. 1996. Fermentation strategies for improving the fitness of a bioherbicide. Weed Technol. 10:645-650.

Johal, G.S., and Briggs, S.P. 1992. Reductase activity encoded by the HM1 disease resistance gene in maize. Science 258:985-987.

Johnson, C.W. III, and Coble, H. D. 1986. Crop rotation and herbicide effects on the population dynamics of two annual grasses. Weed Sci. 34:452-456.

Jorgensen, H.J.L., Andresen, H., and Smedegaard-Petersen, V. 1996. Control of Drechslera teres and other barley pathogens by preinoculation with Bipolaris maydis and Septoria nodorum. Phytopathol. 86:602-607.

Jorgensen, H.J.L., Lubeck, P.S., Thordal-Christensen, H., de Neergaard, E., and Smedegaard-Petersen, V. 1998. Mechanism of induced resistance in barley against Drechslera teres. Phytopathol. 88:698-707.

Kadir, J. 1997. Development of a bioherbicide for the control of purple nutsedge. Ph.D. Thesis. Univ. Of Florida, Gainesville, FL, USA. 148pp.

Keele, P.E., and Thullen R.J. 1991. Growth and interaction of bermudagrass (Cynodon dactylon) with cotton (Gossypium hirsutum). Weed Sci. 39:570-574.

Kenney, D.S. 1986. DeVine-the way it was developed-an industrialist's view. Weed Sci. 34(Suppl. 1): 15-16.

Klein, T.A., and Auld, B.A. 1995. Evaluation of Tween 20 and glycerol as additives to mycoherbicide suspensions applied to Bathurst burr. Plant Prot. Q. 10:14-16.

Knogge, W. 1996. Fungal infection of plants. The Plant Cell 8:1711-1722.

Kolattukudy, P.E. 1985. Enzymatic penetration of the plant cuticle by fungal pathogens. Annu. Rev. Phyopathol. 23:223-250.

Kolattukudy, P.E., Li, D., Hwang, C.S., and Flaishman, M.A. 1995. Host signals in fungal gene expression involved in penetration into the host. Can. J. Bot. 73 (Suppl. 1), S11601168. 
Kranz, J. 1988. Measuring plant disease. Pages 35-50 in: Experimental Techniques in Plant Disease Epidemiology. J. Kranz and J. Rotem, eds. Springer, Berlin.

Latterell, F. 1975. Phenotypic stability of pathogenic races of Pyricularia oryzae, and its implications for breeding of blast resistant rice varieties. Pages 199-234 in: Horizontal Resistance to the Blast Disease of Rice. Cent. Int. Agric. Trop. Ser. CE-9., C.I.A.T., Mexico.

Leggett, M.E., and Gleddie, S.C. 1995. Developing biofertilizer and biocontrol agents that meet farmer's expectations. Adv. Plant Pathol. 11:59-74.

Leonard, K.J., and Suggs, E.G. 1974. Setosphaeria prolata, the ascigerous state of Exserohilum prolatum. Mycologia 66:281-297.

Levings, C.S., and Siedow, J.N. 1992. Molecular basis of disease susceptibility in the Texas cytoplasm of maize. Plant Mol. Biol. 19:135-147.

Luke, H.H., and Wheeler, H.E. 1955. Toxin production by Helminthosporium victoriae. Phytopathol. 45:453-458.

Lybecker, D.W., King, R.P., Schweizer, E.E., and Zimdahl, R.L. 1984. Economic analysis of two weed management systems for two cropping rotations. Weed Sci. 32:90-95.

Massion, C.L., and Lindow, S.E. 1986. Effects of Sphacelotheca holci infection on morphology and competitiveness of johnsongrass (Sorghum halepense). Weed Sci. 34:883-888.

McWhorter, C.G. 1971. Introduction and spread of johnsongrass in the United states. Weed Sci. 19:496-500.

McWhorter, C.G., and Barrentine, W.L. 1988. Spread of paraffinic oil on leaf surfaces of johnsongrass (Sorghum halepense). Weed Sci. 36:111-117.

McWhorter, C.G., Fulgham, F.E., and Barrentine, W.L. 1988. An air-assist spray nozzle for applying herbicides in ultra low volume. Weed Sci. 36:118-121.

McRae, C.F., and Auld, B.A. 1988. The influence of environmental factors on anthracnose of Xanthium spinosum. Phytopathol. 78 (9):1182-1186.

Mendgen, K., and Deising, H. 1993. Infection structures of fungal plant pathogens - A cytological and physiological evaluation. New Phytol. 124:192-213.

Mercer, P.C., Wood, R.K.S., and Greenwood, A.D. 1975. Ultrastructure of the parasitism of Phaseolus vulgaris by Colletotrichum lindemuthianum. Physiol. Plant Pathol. 5:203-214. 
Mersie, W., and Singh, M. 1989. Benefits and problems of chemical weed control in citrus. Rev. Weed Sci. 4:59-70.

Morin, L., Auld, B.A. , and Brown, J.F. 1993a. Interaction between Puccinia xanthii and facultative parasitic fungi on Xanthium occidentale. Biol.Control 3:288-295.

Morin, L., Auld, B.A., and Brown, J.F 1993b. Synergy between Puccinia xanthii and Colletotrichum orbiculare on Xanthium occidentale. Biol. Control 3:296-310.

Mortensen, K. 1988. The potential of an endemic fungus, Colletotrichum gloeosporioides, for biological control of round-leaved mallow (Malva pusilla) and velevetleaf (Abutilon theophrasti). Weed Sci. 36:473-478.

Munyaradzi, S.T., Campbell, M., and Burge, M.N. 1990. The potential for bracken control with mycoherbicide formulations. Aspects of Appl. Biol. 24:169-175.

Murphy, T.R., Gossett, B.J., and Toler, J.E. 1986. Growth and development of dinitroanilin susceptible and resistant goosegrass (Eleusine indica) biotypes under noncompetitive conditions. Weed Sci. 34:704-710.

Nastasi, P., Frans, R. and McClelland, M. 1986. Economics and new alternatives in cotton (Gossypium hirsutum) weed management programs. Weed Sci. 34:634-638.

Nicholson, R.L., and Epstein, L. 1991. Adhesion of fungi to the plant surface. Pages 3-23 in: The Fungal Spore and Disease Initiation in Plants and Animals. G.T. Cole and H.C. Hoch eds. Plenum Press, New York, NY.

Nicholson, R.L., Jamil, F.F., Snyder, B.A., Lue, W.L., and Hipskind, J. 1988. Physiol. Mol. Plant Pathol. 33:271.

Nicholson, R.L., Kollipara, S.S., Vincent, J.R., Lyons, P.C., and Cadena-Gomez, G. 1986. Proc. Natl. Acad. Sci. U.S.A. 84:5520.

Okoli, C.A.N., Shilling, D.G., Smith, R.L., and Bewick, T.A. 1997. Genetic diveristy in populations of purple nutsedge (Cyperus rotundus L.) and yellow nutsedge (C.esculentus L.). Biol. Control 8:111-118.

Panaccione, D.G., Scott-Craig, J.S., Pocard, J.A., and Walton, J.D. 1992. A cyclic peptide synthetase gene required for pathogenicity of the fungus Cochliobolus carbonum on maize. Proc. Natl. Acad. Sci. USA. 89:6590-6504.

Papavizas, G.C., Dunn, M.T., Lewis, J.A., and Beagle-Ristaino, J. 1984. Liquid fermentation technology for experimental production of biocontrol fungi. Phytopathol. $74: 1171-1175$. 
Phatak, S.C., Sumner, D.R., Wells, H.D., Bell, D.K., and Glaze, N.C. 1983. Biological control of yellow nutsedge with the indigenous rust fungus Puccinia canaliculata. Science 219:1446-1447.

Powell, K.A. 1992. Biocontrol product fermentation, formulation and marketing. NATO ASI Ser. Ser. A Life Sci. 230:381-387.

Prasad, R. 1993. Role of adjuvants in modifying the efficacy of a bioherbicide on forest species: compatibility studies under laboratory conditions. Pestic. Sci. 38:273-275.

Prasad, R. 1994. Influence of several pesticides and adjuvants on Chondrostereum purpureum-A bioherbicide agent for control of forest weeds. Weed Technol. 8:445-449.

Pringle, R.B., and Scheffer, R.P. 1964. Host-specific plant toxins. Ann. Rev. Phytopathol. 2:133-156.

Prior, C. 1990. The biological basis for regulating the release of micro-organisms, with particular reference to the use of fungi for pest control. Aspects of Appl. Biol. 24:231-238.

Quimby, P.C. Jr., Fulgham, F.E., Boyette, C.D., and Connick, W.J. Jr. 1988a. An invert emulsion replaces dew in biocontrol of sicklepod - a preliminary study. Pages 264-270 in: Pesticide Formulations and Application Systems. A. Hovde and G.B. Beestman eds. ASTM-STP 980D Vol. 8. American Society for Testing and Materials, Philadelphia, PA.

Quimby, P.C. Jr., Fulgham, F.E., Boyette, C.D., and Hoagland, R.E. 1988b. New formulations nozzles boost efficacy of pathogens for weed control. Proc. Weed Sci. Soc. 28:52.

Retzinger, E.J., Jr., and Rogers, R.L. 1982. Evaluation of six postemergence overtop herbicides for grass control. Proc. South. Weed Sci. Soc. 35:31.

Rhodes, D.J. 1990. Formulation requirements for biological control agents. Aspects Appl. Biol. 24:145-153.

Ridings, W.H. 1986. Biological control of stranglervine in citrus-a researcher's view. Weed Sci. Suppl. 34:32.

Rosskopf, E.N. 1997. Evaluation of Phomopsis amaranthicola sp. nov. as a biological control agent for Amaranthus spp. Ph.D. Thesis. University of Florida, Gainesville, FL, U.S.A. $187 \mathrm{pp}$.

Sands, D.C., Ford, E.J., and Miller, R.V. 1990. Genetic manipulation of broad host-range fungi for biological control of weeds. Weed Technol. 4:471-474. 
SAS Institute. 1988. SAS/STAT User's Guide, release 6.12, SAS Institute, Cary, NC. Schisler, D.A., Jackson, M.A., McGuire, M.R., and Bothast, R.J. 1995. Use of pregelatinized starch and casaminoacids to improve the efficacy of Colletotrichum truncatum conidia produced in differing nutritional environments. Pages 659-664 in: Proc. of the Eigth Intl. Symp. on Biol. Control of Weeds, Lincoln University, Canterbury, New Zealand. E.S. Delfosse and R.R. Scott eds. DSIR/CSIRO, Melbourne, Australia.

Schroeder, J., and Banks, P.A. 1986. Persistence of norflurazon in five Georgia soils. Weed Sci. 34:595-599.

Schuerger, A.C., Mitchell, D.J., and Kaplan, D.T. 1993. Influence of carbon source on attachment and germination of macroconidia of Fusarium solani f. sp. phaseoli on roots of Vigna radiata grown in hydroponic nutrient solution. Phytopathol. 82:1311-1319.

Shoemaker, R.A. 1959. Nomenclature of Drechslera and Bipolaris, grass parasites segregated from 'Helminthosporium'. Can. J. Bot. 37:879-887.

Shrum, R.T. 1982. Creating epiphytotics. Pages 113-136 in: Biological Control of Weeds with Plant Pathogens. R. Charudattan and H.L. Walker, eds. John Wiley and Sons, New York, NY.

Sivanesan, A. 1987. Graminicolous species of Bipolaris, Curvularia, Drechslera, Exserohilum and their teleomorphs. CAB International, U.K. 261 pp.

Smith, J.A., and Metraux, J.P. 1991. Pseudomonas syringae pv. syringae induces systemic resistance to Pyricularia oryzae in rice. Physiol. Mol. Plant Pathol. 39:451-461.

Smith, R.J. 1982. Integration of microbial herbicides with existing pest management programs. In: Biological Control of Weeds with Plant Pathogens. R. Charudattan and H.L. Walker, eds. John Wiley and Sons, New York, NY. 189pp.

Smith, R.J., Jr. 1986. Biological control of northern jointvetch in rice and soybeans - a researcher's view. Weed Sci. 34 (Suppl. 1):17-23.

Smith, R.J. 1991. Integration of biological control agents with chemical pesticides. Pages 189-208 in: Microbial Control of Weeds. D.O. Te Beest, ed. Chapman and Hall, London.

Smith, R.J., Jr., Fox, W.T., Daniel, J.T., and Templeton, G.E. 1973. Can plant diseases be used to control weeds? Ark. Farm Res. 22:12.

Snyder, B.A., and Nicholson, R.L. 1990. Synthesis of phytoalexin in sorghum as a sitespecific response to fungal ingress. Science 248:1637-1639. 
Standifer, L.C., Wilson, P.W. and Porche-Sorbet, R. 1984. Effects of solarization on soil weed seed populations. Weed Sci. 32:569-573.

Steiner, U., and Schonbeck, F. 1995. Induced disease resistance in monocots. Pages 86-110 in: Induced Resistance to Disease in Plants. R. Hammerschmidt and J. Kuc, eds. Kluwer Acad. Publ., Dordrecht, The Netherlands.

Stowell, L. J. 1991. Submerged fermentation of biological herbicides. Pages 225-261 in: Microbial Control of Weeds. D.O. Te Beest, ed. Chapman and Hall Inc., New York, NY.

Stowell, L., Glatzhofer, J., and Bannon, J. 1987. Influence of pH on efficacy of Alternaria cassiae mycoherbicide. WSSA Abstracts 27:48.

Sugawara, F., Strobel, G., Strange, R.N., Siedow, J.N., Van Duyne, G.D., and Clardy, J. 1987. Proc. Natl. Acad. Sci. USA. 84:3081-3085.

Sugawara, F., Hallock, Y.F., Bunckers, G.D., Kenfield, D.S., Strobel, G., and Yoshida, S. 1993. Phytoactive eremophilanes produced by the weed pathogen Drechslera gigantea. Bio Sci. Biotechnol. \& Biochem. 57:236-239.

Supkoff, D.M., Joley, D.B., and Marois, J.J. 1988. Effect of introduced biological control organisms on the density of Chondrilla juncea in California. J. Appl. Ecol. 25:1089-1095.

Tamma, R.V., and Singh, M. 1987. Norflurazon selectivity in two biotypes of guineagrass (Panicum maximum). Weed Sci. 35:749-752.

Teasdale, J. R., Beste, C.E. and Potts, W.E. 1991. Response of weeds to tillage and cover crop residue. Weed Sci. 39:195-199.

TeBeest, D.O. 1996. Issues and prospects confronting biological control of weeds with plant pathogens in future. Phytoparasitica 24(2):91-95.

TeBeest, D.O., and Templeton, G.E. 1978. Temperature and moisture requirements for development of anthracnose on northern jointvetch. Phytopathol. 68:389-393.

Templeton, G.E. 1982. Biological Herbicides: Discovery, Development, Deployment. Weed Sci, 30:430-433.

Templeton, G.E., and Trujillo, E.E. 1981. The use of plant pathogens in the biological control of weeds. Pages 345-350 in: CRC Handb. Pest Man. in Agric. Vol. II., D. Pimentel. ed. CRC Press Inc., Boca Raton, FL.

Templeton, G.E., and Heiny, D.K. 1989. Improvement of fungi to enhance mycoherbicide potential. Pages 127-151 in: Biotechnology of Fungi for Improving Plant Growth. J.M. Whipps and R.D. Lunsden, eds. British Mycological Society, Cambridge University Press, 
Cambridge, U.K.

Templeton, G.E., TeBeest, D.O., and Smith, R.J. Jr. 1979. Biological weed control with mycoherbicides. Ann. Rev. Phytopathol. 17:301-310.

Trujillo, E.E., Aragaki, M., and Shoemaker, R.A. 1988. Infection, disease development, and axenic culture of Entyloma compositarum, the cause of hamakua pamakani blight in Hawaii. Plant Dis. 72: 355-357.

Tucker, D.P.H. 1979. Weed Control Guide for Florida Citrus. Florida Cooperative Extension Service, Circular 459. Institute of Food and Agricultural Sciences, University of Florida, Gainesville.

Tucker, D.P.H., and Singh, M. 1993. Weed control in commercial citrus production. Pages 127-135 in: Florida Weed Control Guide. D.L.Colvin, ed. IFAS, Fact Sheet FC-107, Florida Cooperative Extension Service, University of Florida, Gainesville, FL, USA.

Turgeon, G., and Yoder, O.C. 1985. Genetically engineered fungi for weed control. Pages 221-230 in: Biotechnology: Applications and Research. R.P. Cheremisinoff, R.P. Ouellette, and R.W. Bartholome, eds. Technomic Pub., Lancaster, U.K.

Van Dyke, C.G., and Trigiano, R.N. 1987. Light and scanning electron microscopy of the interaction of the biocontrol fungus Alternaria cassiae with sicklepod (Cassia obtusifolia). Can. J. Plant Pathol. 9:230-235.

Vezina, C., Singh, K., and Sehgal, S.N. 1965. Sporulation of filamentous fungi in submerged culture. Mycologia 57:722-736.

Walker, H.L. 1980. Alternaria macrospora as a potential biocontrol agent for spurred anoda: Production of spores for field studies. Adv. Agric. Technol., AAT-S-12, USDASEA-AR, New Orleans, LA. USA.

Walker, H.L 1982. Seedling blight of sicklepod caused by Alternaria cassiae. Plant Dis. 66: 426-428.

Walker, H.L. 1983. Control of sicklepod, showy crotalaria, and coffee senna with a fungal pathogen. U.S. Patent No. 4,390,360.

Walker, H.L., and Boyette, C.D. 1985. Biocontrol of sicklepod (Cassia obtusifolia) in soybeans (Glycine max) with Alternaria cassiae. Plant Dis. 70:962-963.

Walker, H.L., and Boyette, C.D. 1986. Influence of sequential dew periods on biocontrol of sicklepod (Cassia obtusifolia) by Alternaria cassiae. Plant Dis. 70:962-963. 
Walker, H.L, and Riley, J.A. 1982. Evaluation of Alternaria cassiae for the biocontrol of sicklepod (Cassia obtusifolia). Weed Sci. 30:651-654.

Walton, J.D. 1996. Host-selective toxins: Agents of compatibility. Plant Cell 8:1723-1733.

Walton, J.D., and Panaccione, D.G. 1993. Host-selective toxins and disease specificity: perspectives and progress. Ann. Rev. Phytopathol. 31:275-303.

Wapshere, A.J. 1974. A strategy for evaluating the safety of organisms for biological weed control. Ann. Appl. Biol. 77:201-211.

Watson, A.K. 1985. Host specificity of plant pathogens in biological weed control. Pages 577-586 in: Proceedings of the VI International Symposium on Biological Control of Weeds. E.S. Delfosse, ed. Canadian Government Publishing Center, Ottawa, Canada.

Watson, A.K. 1989. Current advances in bioherbicide research. Pages 987-996 in: Proc. of the British Crop Prot. Conf. (Weeds). British Crop Prot. Council, The Lavenham Press, Suffolk, U.K.

Weller, S.C., Skroch, W.A. and Monaco, T.J. 1985. Common bermudagrass (Cynodon dactylon) interference in newly planted peach (Prunus persica) trees. Weed Sci. 33:50-56.

Wilcut, J.W., Wehtje, G.R., and Pattterson, M.G. 1987. Economic assessment of weed control systems for peanuts (Arachis hypogaea). Weed Sci. 35:433-437.

Williams, C.S., and Hayes, R.M. 1984. Johnsongrass competition in Soybeans (Glycine max). Weed Sci. 32:498-501.

Winder, R.S. 1990. Weed control with mycoherbicides. Pages 43-50 in: Proc. Workshop Biol. Control of Pests in Canada. Calgary, AB, Oct 11-12 (Alberta Environmental Centre and Alberta Agriculture, eds.), Alberta Environmental Centre, Vagerville, AB, Canada.

Winder, R.S., and Van Dyke, C.G. 1987. The effect of various adjuvants in biological control of johnsongrass (Sorghum halepense) with the fungus B. sorghicola. Proc. Weed Sci. Soc. America. 38:89-94.

Winder, R.S., and Van Dyke, C.G. 1990. The pathogenicity, virulence, and biocontrol potential of two Bipolaris species on johnsongrass (Sorghum halepense). Weed Sci. 38:89-94.

Winder, R.S., and Watson, A.K. 1990. Development of a potential mycoherbicide to control fireweed (Epilobium angustifoliumL.) in reforestation areas. WSSA Abst. 30:49.

Winton, K.T., and Frans, R.E. 1984. Experimental postemergence herbicides for control of johnsongrass in soybeans. Proc. South. Weed Sci. Soc. 37:49. 
Womack, J.G., and Burge,M.N. 1993. Mycoherbicide formulation and the potential for bracken control. Pesticide Sci. 37:337-341.

Womack, J.G., Eccleston, G.M., and Burge, M.N. 1996. A vegetable oil-based invert emulsion for mycoherbicide delivery. Biol. Control 6:23-28.

Wymore, L.A., and Watson, A.K. 1986. An adjuvant increases survival and efficacy of Colletotrichum coccodes, a mycoherbicide for velvetleaf (Abutilon theophrasti).

Phytopathol. 76:1115-1116.

Wymore, L.A., and Watson, A.K. 1989. Interaction between a velvetleaf isolate of Colletotrichum coccodes and thidiazuron for velvetleaf(Abutilon theophrasti) control in the field. Weed Sci. 37:478-483.

Wymore, L.A., Watson, A.K., and Gotlieb, A.R. 1987. Interaction between Colletotrichum coccodes and thidiazuron for control of velvetleaf(Abutilon theophrasti). Weed Sci. 35:377383.

Wynn, W.K., and Staples, R.C. 1981. Tropisms of fungi in host recognition. Pages 45-69 in: Plant Disease Control: Resistance and Susceptibility. R.C. Staples and G.H.

Toenniessen, eds. John Wiley \& Sons, New York, NY.

Yandoc, C.B., and Charudattan, R. 1998. Use of natural substrates for the production of fungal inoculum for biological weed control studies. WSSA Abstracts 38:80.

Yang, G., Rose, M.S., Turgeon, B.G., and Yoder, O.C. 1996. A polyketide synthase is required for fungal virulence and production of the polyketide T-toxin. Plant Cell 8:21392150.

Yang, S.M., Johnson, D.R., Dowler, W.M., and Connick, W.J. Jr. 1993. Infection of leafy spurge by Alternaria alternata and A. angustiovoidea in the absence of dew. Phytopathol. 83:953-958.

Yang, S.M., and Schaad, N.W. 1998. Effect of a weakly virulent fungus combined with an invert adjuvant carrier on Papaver spp. Phytopathol. 88(9) (Suppl.): S 101.

Zhang, W.M., Moody, K., and Watson, A.K. 1996. Responses of Echinocloa species and rice (Oryza sativa) to indigenous pathogenic fungi. Plant Dis. 8:1053-1058.

Zhang, W.M., and Watson, A.K. 1997a. Effect of dewperiod and temperature on the ability of Exserohilum monoceras to cause seedling mortality of Echinocloa species. Plant Dis. 81(6):629-634. 
Zhang, W.M., and Watson, A.K. 1997b. Efficacy of Exserohilum monoceras for the control of Echinocloa species in rice (Oryza sativa). Weed Sci. 45:144-150.

Zhang, W.M., and Watson, A.K. 1997c. Host range of Exserohilum monoceras, a potential bioherbicide for the control of Echinocloa species. Can. J. Bot. 75:685-692. 


\section{BIOGRAPHICAL SKETCH}

S. Chandramohan was born to Mr. G. Sankaranarayanaiyer and Mrs. P. Saraswathy Ammal on May 20, 1962, in Nagercoil, Tamilnadu, India. He received a B.S. degree in agriculture in 1983 from Annamalai University, Tamilnadu, and a M.S. degree in Agricultural Microbiology in 1986 from the Tamilnadu Agricultural University, Coimbatore, Tamilnadu, India. From 1986 to 1988, he worked as a Research Associate in Microbiology, Legumes Program, International Crops Research Institute for the Semi-Arid Tropics, a member institute of the Consultative Group on International Agriculture Research, Patancheru, Andhra Pradesh, India.

In 1988, Mr. Chandramohan was awarded a scholarship from the Belgian Administration for Overseas Development Cooperation to pursue an international postgraduate program in Molecular Biology. He earned his M.S. in Molecular Biology in January 1991 from Vrije Universiteit Brussels, St. Genesius Rode, Belgium.

He began his Ph.D. study at the University of Florida in Fall 1994. He was awarded the Oustanding Graduate Student Award for excellence in research in the Department of Plant Pathology in 1998. Upon completion of his Ph.D. program, he plans to pursue a career focusing on research and development in microbial biotechnology for weed and plant disease management. 
I certify that I have read this study and that in my opinion it conforms to acceptable standards of scholarly presentation and is fully adequate, in scope and quality, as a dissertation for the degree of Doctor of Philosophy.

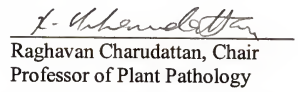

I certify that I have read this study and that in my opinion it conforms to acceptable standards of scholarly presentation and is fully adequate, in scope and quality, as a dissertation for the degree of Doctor of Philosophy.

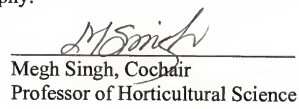

I certify that I have read this study and that in my opinion it conforms to acceptable standards of scholarly presentation and is fully adequate, in scope and quality, as a dissertation for the degree of Doctor of Philosophy.

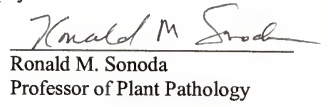

I certify that I have read this study and that in my opinion it conforms to acceptable standards of scholarly presentation and is fully adequate, in scope and quality, as a dissertation for the degree of Doctor of Philosophy.

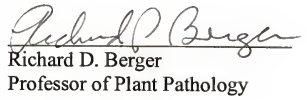

I certify that I have read this study and that in my opinion it conforms to acceptable standards of scholarly presentation and is fully adequate, in scope and quality, as a dissertation for the degree of Doctor of Philosophy.

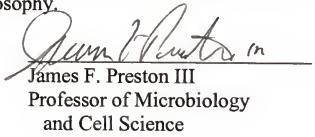


This dissertation was submitted to the Graduate Faculty of Agriculture and to the Graduate School and was accepted as partial fulfillment of the requirements for the degree of Doctor of Philosophy.

August, 1999

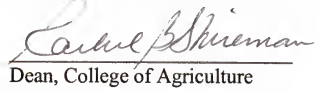

Dean, Graduate School 